\author{
UNITED STATES \\ DEPARTMENT OF THE INTERIOR \\ GEOLOGICAL SUAVEY
}

\title{
SUMMARY OF REFERENCES TO MINERAL OCCURRENCES \\ (OTHER THAN MINERAL FUELS AND CONSTRUCTION MATERIALS)
}

IN THE FAIRBANKS QUADRANGLE. ALASKA

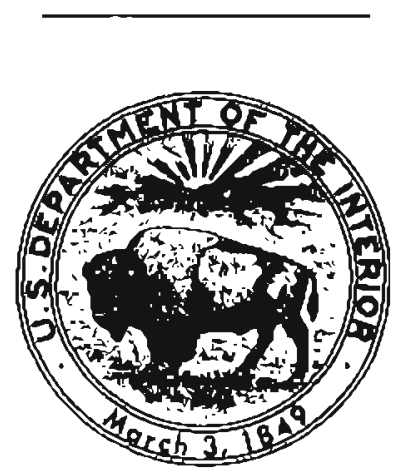

OPEN-FILE REPORT 76-682

This report is preliminary and has not bean edited or reviewed for conformity with Geological Survey standards and nomenclature 


\section{UNITED STATES \\ DEPARTMENT OF THE INTERIOR \\ GEOLOGICAL SURVEY}

\section{SUMMARY OF RPFERENCES TO MINERAL OCCURRENCES \\ (OTHER THAN MINERAL FUELS AND CONSTRUCTION MATERIALS) \\ IN THE FAIRBANKS QUADRANGLE, ALASRA}

By

Edward H. Cobb

Open-f1le report $76-662$

1976

Th1s report la prelimiary and has not been edited or revlewed for conformity with Geological Survey atandards. 


\section{Introduction}

These sumarles of references are destgned to ald in library research on metallic and nometallic (other than mineral fuels and construction materials) mineral occurrences in the Falrbanks quadrangle, Alaska. All references to reports of the Geological Survey, to most reports of the U.S. Bureau of Mines, and to most reports of the State of Alaska Division of Geologlcal and Geophysical Surveys and 1 ts predecessor State and Terrttorlal agencles released before January 1 , 1976, are sumarized. Certain, malaly statlstical, reports such as the annual Minerals Yearbook of the U.S. Bureau of Mines and the biennial and annual reports of the State of Alaska Division of Geological and Geophystcal Surveys and 1 ts predecessor State and Territorlal agencies are not included.

This report is divided 1nto three parts: a sectlon made up of sumarles of references arranged alphabetically by occurrence name; a section that lists synonyms for aames in the first section, claim names, and the names of operators and owners of mines and prospects; and a section that lists, by author, all references sumartzed in the first section. 


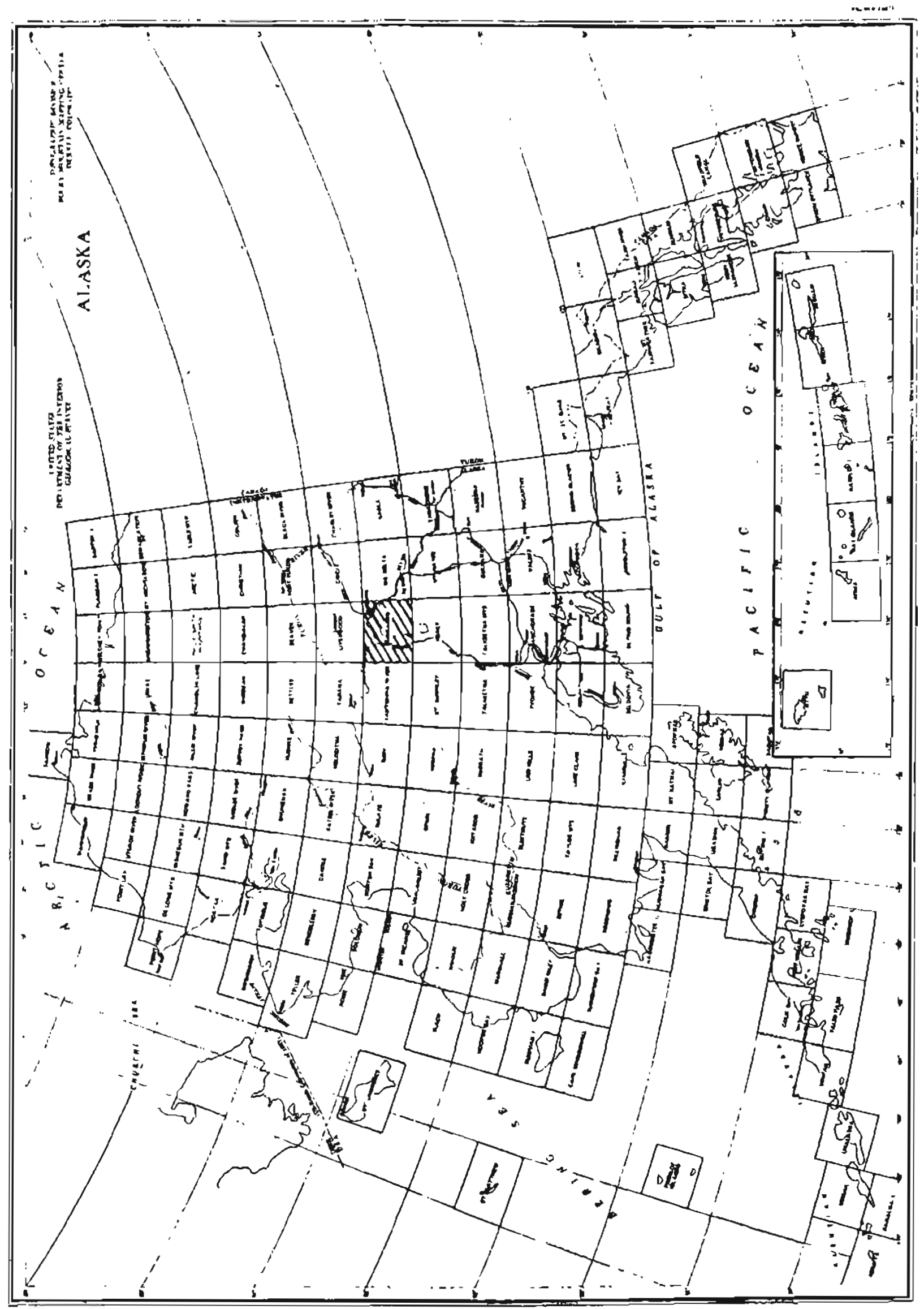




\section{Sumarles of References}

Por each mineral occurrence there is a page that gives the name of the occurrence; the mineral commoditles present (11sted alphabet1cally for metallic commodities and then for nonmetallic comodities); the mining district (Ransome and Kerns, 1954) In which the occurrence Is located; the name of the 1:250,000-scale topographic quadrangle (Falrbanks); coordinates (as described by Cobb and Kachadoorian, 1961, p. 3-4); the metall1c mineral resources map number (MF-410) and the occurrence number on that map if the occurrence $1 \mathrm{~s}$ shown; and the latitude and longltude of the occurrence. These data, presented at the top of the page, are followed by a short, general sumary of the published information on the occurrence. This is followed (continued on addftional pages, if necessary) by more detalled sumaries, arranged chronologlcally, of all references to the occurrence. Material in brackets is interpretive or explanatory and is not in the sumarlzed reference.

Proper names of mines, prospects, and other mineral occurrences are given if such names appear in the reports sumarized. If a deposit does not have such a name, but is near a named geograph1c feature, the name of that feature is shown in parentheses in Ileu of a proper name. One deposit that has no proper name and is not near a named geographic feature is titled "Unnamed occurrence" and appears at the end of the 11st. If a part of a proper name is not always used in a reference, that part of the rame is shown in parentheses. This is most comon in company names and in place names with minor varlations in spelling.

Citations are given in standard bibllographlc format with the exception that references to reports and maps in numbered publication series also show, in parentheses, an abbreviation for the report or map series and the report or map number. Abbrevlations used are:

\begin{tabular}{|c|c|}
\hline B & U.S. Geological Survey Bullerin \\
\hline BMA & U.S. Bureau of Mines Bulletio \\
\hline C & U.S. Geologlcal Survey Circular \\
\hline GC & $\begin{array}{l}\text { Alaska Dlviglon of Geologlcal and Geophysical Surveys } \\
\text { (and predecessor State agencies) Geochemical Report }\end{array}$ \\
\hline GQ & U.S. Geologlcal Survey Geologic Quadrangle Map \\
\hline IC & U.S. Bureau of Mines Information Circular \\
\hline OF & $\begin{array}{l}\text { U.S. Geologtcal Survey Open-file Report (numbers are } \\
\text { Informal and used only within the Alaskan Geology } \\
\text { Branch of the U.S. Geological Survey) }\end{array}$ \\
\hline MF & $\begin{array}{l}\text { U.S. Geological Survey Miscellaneous Fleld Studies } \\
\text { Map }\end{array}$ \\
\hline p & U.S. Geological Survey Professtonal Paper \\
\hline RI & U.S. Bureau of Mines Report of Investigations \\
\hline TDM & Alaska Territorial Department of Mines Pamphlet \\
\hline USBM OF & U.S. Bureau of Mines Open-file Report \\
\hline
\end{tabular}


Sumaryes are as I made them whlle reading the clted reports. I made no attempt to use complete sentences and did not edit for gramwatfcal consistency, although I have tried to edit out amblguities.

References clted only in these introductory paragraphs are:

Cobb, E. H., and Kachadoorian, Reuben, 1961, Index of metallic and nonmetallic mineral deposits of Alaska complled from published reports of Federal and State agencles through 1959: U.S. Geol. Survey Bull. $1139,363 \mathrm{p}$.

Ransome, A. L., and Kerns, W. H., 1954, Names and definitions of reglons, districts, and subdistricts in Alaska (used by the Bureau of Mines in statistical and economlc studies covering the mineral industry of the Territory): U.S. Bur. Mines Inf. Circ. $7679,91 \mathrm{p}$. 
(Alder Cr.)

Falrbanks district
Gold (?)

Falrbanks (14.3, 14.6) approx. $64^{\circ} 45^{\prime} \mathrm{N}, 148^{\circ} 05^{\prime}$ '. approx.

Sumary: Posstbly aurtferous gravels were prospected in 1907. No definfte report of mining. Location on creek not given.

Brooks, 1908 (B 345), p. 41-42 -- Gravels carefully prospected, 1907. [The statement on $p .41$ is that gold was present, that on $p .42$ is that Brooks does not know if values were found.]

Prindle, 1908 (B 337), p. 45-46 - No gold has been mined; gravels said to be auriferous. Prospect drilling (results not known), winter of 1907.

El1sworth and Parker, 1911 (B 480), p. 158 -- Very 11ttle actual mining In 1910. 
Summary: A few thousand tong of clay in floodplain of Nenana R. are sultable for manufacture of comon brick.

Eckhart, 1952 (OF 66) -- Clay depostt 1s part of flood plain of Nenana R. Four flat-lying, probably lenticular undta of tan, gray, and dark clay. Lowest 3 units (dark and gray clay) are sultable for manufacture, of comon brick. Inferred reserves (calculated from auger holes) are 13,000 short tons, of which 4,900 tons are in unles sultable for brlck. Deposit not fully outlined. 
(A11en CT、)

Fatrbanks district
Gold (?)

Fa1rbanks $(13.0,15.0)$ approx. $64^{\circ} 50^{\circ} \mathrm{N}, 148^{\circ} 15^{\prime} \mathrm{W}$ approx.

Sumary: Prospects reported, but not conf1rmed.

Ellaworth, 1912 (B 520), P. 241 -- "Good prospects were found on Allen Creek, a small tributary of Goldstream" In 1911. [This is the only mention of this creek. No creek within about $4 \mathrm{ml}$. of Allen Cr. has reported placer depostes; no reported lode depostis in dralnage basin.] 
Falrbanks district

Fa1rbanks $(19.9,17.5)$

MF-410, 10c. 35

$64^{\circ} 59^{\prime} \mathrm{N}, 147^{\circ} 19^{\circ} \mathrm{W}$

Sumary: Brecclated schlst partly cemented by quartz and an trregular quartz vein. Very few oulfides. Gold can be panned from most random samples of quartz. Several tons of ore (gold tenor $\$ 24$ per ton) have been mined; Inclined shaft $60 \mathrm{ft}$. long. Includes reference to Perrault.

Solth, 1913 (8 525), P. 166 - Veln $18 \mathrm{fn}$. to $4 \mathrm{ft}$. wlde, averaging 2 ft. Several tons of ore mined; gold tenor was $\$ 24$ per ton.

Sm1th, 1913 (B 542), p. 151 - Same as B 525.

Chapln, 1914 (B 592), p. 329-330 - Quartz veln sald ro strike $N 50^{\circ} \mathrm{E}$ and dip $60^{\circ} \mathrm{NW}$; varles from $6 \mathrm{In}$. to $3-1 / 2 \mathrm{ft}$. In thickness; inclined shaft $60 \mathrm{ft}$. Iong. Two generations of quartz; very few sulftdes. Footwall is a zone of schist $3 \mathrm{ft}$. Wide with small quartz stringerg. Gold can be panned from most random samples of quartz.

H11, 1933 (B 849-B), P. 154 -- Work1ngs Inaccesstble In 1931. Materlal on dumps is breccia of schist fragments partly cemented by quartz. Reference to B 525, p. 166.

Chapman and Foster, 1969 (P 625-D), P. D15 -- References to B 525, p. 166, and B 592, p. 329-330. [L1sts scheelite, but none 1s mentioned In clted reports.] 
American Eagle

Falrbanke dlatrlet

MF $-410,10 \mathrm{c} .35$
Cold

Fa1rbanks (19.9, 17.5)

$64^{\circ} 59^{\prime} \mathrm{N}, 147^{\circ} 19^{\prime} \mathrm{W}$

Summary: Veln 18 in. wide carries about $1,2 \mathrm{oz}$, gold per ton. 20 tons ore mined (but not shlpped) in 1911. Shaft $38 \mathrm{ft}$. deep.

See also American.

Stotch, 1913 (B 525), p. 166 -- Veln averages 18 1n. wide, $\$ 25$ per ton in gold. Shaft $38 \mathrm{ft}$. deep. 20 tons ore mined but not shipped in 1911. Dike (character not known) sald to cut veln and to carry $\$ 15$ per ton in gold.

Solth, 1913 (B 542), P. 195 - Same as B 525.

H111, 1933 (B 849-B), P. 154 -- Reference to B 525.

Chapman and Foster, 1969 (P 625-D), P. D15 -- Reference to B 525. 
Anderson

Falrbanks district

$M-410,20 c .27$
Gold (?), Tungsten

Faltbanks $(18.3,17.0)$

$64^{\circ} 57^{\prime} \mathrm{N}, 147^{\circ} 32^{\prime} \mathrm{W}$

Summary: Quartz vein cuts across follation of mica schist. Scheelite along outer edge of veln, but not within the quartz or in the schist.

Mertle, 1918 (B 662), P. 424 -- Quartz stringer strikes N $50^{\circ}$ E, dipg $55^{\circ} \mathrm{NW}$; foliation of mica schist country rock Btrikes $\mathrm{N} 60^{\circ} \mathrm{E}$, dips $20^{\circ} \mathrm{W}$. Scheelite reported along outer edges of veln, but not within veln or in schist.

Thorne and others, 1948 (RI 4174), p. 26 -- Quotation from B 662.

White and others, 1952 (C 196), p. 9 -- Sheared quartz vein in granitic rock; gold and several of the comon sulfides.

Chapman and Foster, 1969 (P 625-D), P. D16 -- Reference to B 662. 
(Antimony Ryàge)

Eairbanks olstrict

MF-410, 10c. 22
Antimony, Gold

Fafrbanks $(16.65,17.65)$

$65^{\circ} 00^{\prime} \mathrm{N}, 147^{\circ} 46^{\prime} \mathrm{W}$

Summary: Shear zone assoclated with fault in schistose quartzite and alca schist. Stibnite in lenses and nodules; sheared vetn quartz. Samples across vein contalned 3:40:c0 69.00 (average 16.1) ppo gold. Shaft (depth not given) on prospect.

Chapman and Foster, 1969 (P 625-D), p. D14 -- Sttbntte in breccia assoclated with NE-trending reverse Eault in schistose quartzite and mica schist: Shaft [depch not stared].

Pilkington and others, 1969 (OF 383), p. 4-6 -- Vein trends $N 47^{\circ} \mathrm{E}$, dipg $60^{\circ} \mathrm{SE}$. Major and wany substdiary shears. Stibnite occurs as lenses or nodules surrounded by sheared materlal. Analyses of channel samples across vein range from 3.40 to 69.00 and average $16.1 \mathrm{ppm}$ gold. 
Fairbanks district

Fairbanks $(14.4,15.5)$

MF-410, Ioc. 4

$64^{\circ} 52^{\prime} \mathrm{N}, 148^{\circ} 04^{\prime} \mathrm{W}$

Sumary: Four cons of ore mined from a steeply dipping quartz vein ylelded "falr returns." About $200 \mathrm{ft}$. of workings.

Smith, 1913 (B 525), p. 209 - Quartz veln trends NW and d1ps steeply NE. Quartz on dump; gold content small; practically no sulfides.

Sm1th, 1913 (B 542), p. 195 -- Same as B 525.

Chapin, 1914 (B.592), P. 352-353 - Two shafts were sunk 40 and $45 \mathrm{ft}$. and an Incline driven along a narrow $\mathrm{atrlnger}$ for $100 \mathrm{ft}$. Drift cut a ledge sald to be $4 \mathrm{ft}$. wlde. 4 tons of ore mined and milled; ylelded falr returns.

Chapman and Foster, 1969 (P 625-D), P. D19-- References to B 525, B 592 . 
B19 Blue

Fa1rbanks digtrict
Gold (?)

Fa1rbanks $(14.75,15.6)$

$64^{\circ} 53^{\prime} \mathrm{N}, 148^{\circ} \mathrm{O} 1^{\prime} \mathrm{W}$

Sumbry: Crushed sch1st, quartz, and gouge in fault zone. No data on metallic content, if any.

H111, 1933 (B 849-B), P. $148-$ Vetn exposed 1n shallow shafts and p1ts; strikes $\mathrm{N} 27^{\circ} \mathrm{E}$. Apparently occuples faulted zone with wuch crushed schiot, quartz, and gouge.

Chapran and Foster, 1969 (P 625-D), P. D18 -- Reference to B 849-B. 
(81g Eldorado $\mathrm{Cr}$. )

Fa1rbanks district

MF- $410,10 \mathrm{c} .51$
Gold

Fatrbank: $(16.45-16.9,17.15-17.5)$

$64^{\circ} 58^{\prime}-64^{\circ} 59^{\prime} \mathrm{N}, 147^{\circ} 44^{\prime}-147^{\circ} 47^{\prime} \mathrm{W}$

Sumbry: Stream flows in asymetrlcal valley. Thlck mass of terrace deposits on gentle slope. In upper part of valley gold is In gravel $50 \mathrm{ft}$. deep. Has been minor production of gold. Includes reference (Prindle and Katz, 1913 (B 525), p. 106) to Eldorado $\mathrm{Cr}$.

Brooks, 1908 (B 345), P. 42 -- Small production, 1907.

Prindle, 1908 ( $B$ 337), p. 39, 41 -- Gold has been found. Paystreak ald to be narrow; has been some mining (as of 1907).

Prtndle and Katz, 1908 (B 379), p. 191 - On 2 clalms depths to bedrock are 54 and $98 \mathrm{ft}$. (thicknesses of muck are 20 and $38 \mathrm{ft}$. respecttvely).

Prindle and Katz, 1913 (B 525), p. 106 -- IGiven as Eldorado Cr. In reference; context makes tt certaln that data are for Blg Eldorado Cr.l Th1ck mass of terrace depostts on gentle slope. Gold in upper part of valley in gravel $50 \mathrm{ft}$. deep and $30 \mathrm{ft}$. Wlde. Valley asymetrlcal; stream close to steep SE wall.

p. 111 - Production through 1910 was worth $\$ 50,000$.

p. 113 -- Average value of gold per oz. Is $\$ 19.38$.

Brooks, 1916 (B 642), p. 59 - Mining, 1915.

Sutth, 1917 (BMB 153), P. 51 - Mining, 1916. 
B11ly Sunday

Falibanks distrlct Maf -410, loc. 18
Antimony, Gold, Lead, Zlne

Falrbanks (15.0, 15.4)

$64^{\circ} 52^{\prime} \mathrm{N}, 148^{\circ} 00^{\prime} \mathrm{W}$

Summary: Minerallzed zone 3-11 ft. wlde with gold-quartz veln 2-3 ft. thick. Ore contalns free gold, arsenopyrite, stibnice, cervantite, sphalertte, and galena. Developed by fnclined ahaft and 4 levels of drifts. Gold worth $\$ 50,000$ (about 2,400 fine oz.) recovered from 1,900 tong of ore mined from 1918 to 1923. Includes references to: $B 112$ Sunday Fraction, Leah fraction, Lean Fraction, Smith \& McGlone, Smith \& McGonalgle, Smith Bros.

Mercie, 1928 (B 662), p. 412-413 - Work on Leah fraction consists of 95-ft. Bhaft. Vein of gold quartz 2-3 ft. thick $1 \mathrm{n}$ and parallel to mineralized zone 3-11 ft. wide. Veln strikes $N 4^{\circ} \mathrm{E}$, dips $55^{\circ} \mathrm{SE}$. Quartz 1s broken and shactered; contalns atibnite and o little sphalertte. Shattered rock next to quartz veln filled with quartz stringers; carries gold and may be minable.

Chapla, 1919 (B 692), P. 323 - Development wark continued, 1917. On B113y Sunday Fraction lode strikes N $25^{\circ} \mathrm{E}$ and dips $70^{\circ} \mathrm{SE}$ to nearly vertical, is $3 \mathrm{ft}$. whde surface and widens downard; gouge and winerallzed schist at $50 \mathrm{ft}$; contalns stibnite, cervantite, and free gold.

Martin, 1920 (B 712), P. 40 -- Operated May-October, 1918; 2 mII runs made.

Brooks and Martin, 1921 (B 714), p. 81 -- Minor production, 1919. Brooks, 1922 (B 722), P. 45 - Minor production, 1920.

Brooks, 1923 (B 739), p. 30 -- Mtring, 1921.

Brooks and Capps, 1924 (B 755), p. 35 -Development, 2922; pump to be Installed.

Brooks, 1925 (B 773), p. $15-$ Mtning, 1923.

H111, 1933 (B 849-B), P. 139-142 - About $\$ 50,000$ produced from 1,900 rons of ore from stopes above 120-ft. Ievel and winze on 200-ft. level. Mine not operated since 1923. Inclined shaft and drifts on 4 levels. Veing are 1rregular, as much as $5 \mathrm{ft}$. wide, and contsst of quartz and erushed schtst. Some schtat near veins also rotneralized; gold, stibntte, and arsenopyrtte.

Kulieen and Mertie, 1951 (OF 42), p. 17-18-Reference to B 662, p. 413; B 692, p. 323.

Chapman and Foster, 1969 (P 625-D), P. D17 -- References to B 662, B 849-B. Galena also reported. 
Blossom

Falrbanks district MF-410, 10c, 27
Tungsten

Falridanks $(18.3,17.0)$

$64^{\circ} 57^{\prime} \mathrm{N}, 147^{\circ} 32^{\prime} \mathrm{W}$

Sumary: Bedrock 18 quartz-mica and amphibole schists intruded by a porphyrit1c grante dike. Scheellte in quartz-scheelite stringers and in thin zones in schist in contact with the stringers. No tactite developed. Old workings (2 shafts, trenches, and p1ts) caved. Selected samples from dumps contalned $1.44 \%$ and $2.02 \% \mathrm{WO}_{3}$. Includes reference to Black Bear.

Mertie, 1918 (B 662), p. 422 -- Along western periphery of large mass of porphyritic grantie.

p. 424 -- Shaft said to have exposta a rich stringer of scheel1te. Granlte porphyry dike in bottow of shaft. Another shafe $20 \mathrm{ft}$. deep opened a scheelite lode $3-4 \mathrm{ft}$. thick.

Chapln, 1919 (B 692), p. 327 -- Quartz stringer lodes in schist in places carry large crystals of scheelite; exposed by trenching.

Thome and others, 1948 (RI 4174), P. 24, 26- Quotations from B 662, and statement that clalms were restaked in 1942.

Byers, 1957 (B 1024-I), P. 201 -- Had been lacated by 1916. Prospecting for 2 or 3 years; workings all caved by 1942 .

p. 203-204 -- Workings (a11 caved) consisted of 2 shafts and 23 trenches and pits. Bedrock is quartz-mica and amphibole schists intruded by a porphyritlc granite dike. Scheellte is in quartzscheelite stringers and 1n thin zones in schist in contact with quartz stringers. No tactites developed. Selected samples from dumps contalned $1.44 \%$ and $2.02 \% \mathrm{WO}_{3}$.

Berg and Cobb, 1967 (B 1246). p. 220 -- On ridge between steele and First Chance Creeks where the scheelite deposits are in tactite, silicated limestone, grantte and pegmatitlc dikes, and gmall quartz veins in schist.

Chapman and Foster, 1969 (P 625-D), P. D16 - References to B 692, p. 327 , and $B$ 1024-I, P. 203-204.

Mulligan, 1974 (IC 8626), p. 13 -- Pegmat1te-type quartz-scheelite stringers penetrate quartz-biotite schist ano porphyritic granite. 
Blue Bonanza

Falrbanks dibtrict MF-410, 10c. 8
Antionon, Gold, Lead, S1lver

Fa1rbanks $(14.5,15.8)$

$64^{\circ} 53^{\prime} \mathrm{N}, 148^{\circ} 04^{\prime} \mathrm{W}$

Sumary: Quartz veln 18 ln. thick at burface narzows with depth; very rich (In gold) pockets near ouxface. Sulfides in vein include galena, pyitte, stibnite, and argentiferous tetrahedrice. Inclined shaft and stopes. 10 tons of ore reported to have been mined. Includes references to: Grant, near Nugget $\mathrm{Cr}$.; Midnight Sun.

Swth, 1913 (B 525), p. 297 - Inclined (35०) shaft on IIne between Blue Bonanza and Midnlght Sun clatms. 18-inch quartz vein that narrows with depth. Two perlods of vein formation; older quartz crushed and has cavities opened alnce crushing. Younger quartz has glassy crystals and ts banded parallel to walls; contalns galena, pyrtte, and some stibnite along walls and between crystals. Gold visible near and remote from sulfides. Considerable silver (In tetrahedrite).

Smich, 1913 (B 542), P. 183 - Same as B 525.

Chap1n, 1914 (B 592), p. 353 -- Shaft $130 \mathrm{ft}$. deep. Surface zone 12-15 $f t$. deep contalned pockets of very rich ore; below this zone rock has low gold content.

Kil1, 1933 (B 849-B), D. 122 - Ve10 5-6 In. wide. Quartz contains small amounts of arsenopytite and stibnite. Vein strikes $\mathrm{N} 10^{\circ} \mathrm{W}$, dips $65^{\circ} \mathrm{E}$. Shaft more than $60 \mathrm{ft}$. deep, stopes. 10 tons ore sa1d to have been mined. Grab sample from dump contalned $\$ 9.22$ per ton in gold.

K1Ileen and Mert1e, 1951 (OF 42), p. 19 -- References to B 525 and B 849-B.

Chapman and Foster, 1969 (P 625-D), P. D18 -- References co B 525 and B 592 . 
(Boanifleld Cr.)

Bonnifield dibtrict

$M F-410,10 c .83$
Gold

Falrbanks ( $15.75,1.35)$ approx. $64^{\circ} 04^{\circ} \mathrm{N}, 147^{\circ} 56^{\prime} \mathrm{W}$ approx.

Summary: Small-scale mintng reported in 1929 and 1935. There was undoubtedly progpecting or mining in other years as well.

Smlth, 3932 (B 824), p. 40 -- Mining, 1929; no more than a few hundred dollars worth of gold produced.

Smith, 2937 (B 880-A), p. 46 -- Small-scale minling, 1935.

Cobb, 1973 (B 1374), P. 111 -- Has been one of the least product1ve creeks in the district. 
Brown

Falrbanks district
Gold (?)

Falrbarks (18.7, I7.3)

$64^{\circ} 58^{\prime} \mathrm{N}, 147^{\circ} 29^{\prime} \mathrm{W}$

Sumary: In 1913 Brown was prospecting several elaims near a contact between porphyritlc granire and schlot.

Chap1n, 1914 (B 592), P. 345 -- Several clalms near contact between porphyritlc grantte and schist betng developed, 1913.

Chapman and Foacer, 1969 (P 625-D), P. D16 -- Reference to B 592. Mulligan, 1974 (IC 8626), P. 13 -- Near contact between porphyrit1c grantte and schist. 
Bunker H112

Falrbanks district

MF-410, 10c. 23
Gold

Folrbanks $(17.1,17.7)$

$65^{\circ} 00^{\prime} \mathrm{N}, 147^{\circ} 42^{\prime} \mathrm{W}$

Summary: Gold-quartz veln 2-12 in. thick In schlat. Test shipment of 8 tons of material from near surface milled 13 oz. of gold. Shaft over $100 \mathrm{ft}$. deep, 2 hort drifts. See also Goodwin.

Chap1n, 1914 (B 592), p. 345 -- Test shipment of 8 tons of ore, 1913. Vein gald to be $24 \mathrm{in}$. wide at gurface.

R111, 1933 (B 849-B), p. 154 -- Owner (Goodw1n) stated that shaft was $102 \mathrm{ft}$. deep on a veln that str1kes $\mathrm{N} 15^{\circ} \mathrm{W}, \mathrm{d} 1 \mathrm{ps} 70^{\circ} \mathrm{E}$, averages $12 \mathrm{in}$. wide at surface and narrows to $2 \mathrm{tn}$. at depth of $50 \mathrm{ft}$. Short drifts on 25-ft. and 60-tt. levels. Material on dump 15 mica schlst from hanglng wall and blocky quartz-mica schlst from footwall. 8 tons of ore milled $13 \mathrm{oz}$. of gold. Grab sample of ore from dump assayed $\$ 24.06$ per ton.

Chapman and Poster, 1969 (P 625-D), P. D15 -- [Called Bunker H1ll mine.] References to B 592 and 849-B. 
(Califormia Cr., lode)

Bonniffeld distict

MF-410, 2oc. 41
Antimony, Blsmuth, Copper, Gold, Lead, S1lver

Falrbanks $(9.8,1.25)$

$64^{\circ} 04^{\prime} \mathrm{N}, 148^{\circ} 43^{\prime} \mathrm{W}$

Summary: Small velns of complex ore; lead-antimony sulfide (probably jamesonite), blsmuthinite, arsenopyrite, pyrite, and sulfides and sulfosalts that carry antimany, lead, copper, arsentc, and silver. Stibnite, chalcopyrite, and argentiferous galena also reported. Quartz gangue. Some development, 1934-35. Selected ore shipped for testing. Assays for sllver as high as $600 \mathrm{oz}$. per ton. One sample contained $0.27 \mathrm{oz}$. gold per ton. Copper obtained from concentrates. Includes references to Prospect Mining Co.

Smith, 1936 (B 868-A), p. 24 -- Developed malnly for silver; subordinate amounts of gold and copper.

p. 63 -- Active prospecting in 1934. Ore carries some gold, considerable copper, a little lead; most valuable component is silver. Selected ore shipped for metallurgical testing.

p. 66-67-- Copper obtalned from concentrates.

Smith, 1937 (B 880-A), P. 28 -- Discontinued operations in midsaason, 1935.

p. 65 -- Country rock mainly sch1st. Work discontinued, September, 1935.

p. 70 -- Copper obtalned from concentrates.

Joesting, 1943 (TDM 2), P. 13-14 - Several small antimony-bearing veins. Ore 1 s complex; lead-antimony sulfide (probably jamesontte), sulfides and sulfantimonates of copper, argentc, and silver, and small amounts of bismuthinite, arsenopyrite, and pyrfte. Smald fissure vetn (Danzinger lode) unsuccessfully mined; sample assayed $0.27 \mathrm{oz}$. Au and $259 \mathrm{oz}$. Ag per ton; other samples as high as $600 \mathrm{oz}$. Ag per. tor.

Wedow and others, 1952 (OF 51), p. 72 - A few carloads of ore reported to have been produced.

White and others, 1952 (C 196), p. 9 -- Stibntte, pyrtte, and chalcopyrite; silver-bearing galena; in quartz gangues.

Berg and Cobb, 1967 (B 1246), p. 202-203 -- Small velns contaln arsenopyrite, pyrite, bismuthinite, and oulfosalts that carry antimony, lead, zlnc (?), copper, arsentc, and ollver. 
(California Cr., placer)

Bonnifleld detrict

MF $-410,10 c 8.66,67$
Gold, Mercury, Platinum

Fa1 rbanks $(9.7-9.9,0.85-1.5)$

$64^{\circ} 03^{\prime}-64^{\circ} 05^{\prime} \mathrm{N}, 148^{\circ} 43^{\prime}-148^{\circ} 44^{\prime} \mathrm{W}$

Sumary: Creek flows through 3 baslos separated by canyons cut through sch1st ridges. Most mining was at head of canyon about $5 \mathrm{ml}$. above Rex Cr. In stream gravels on sch1st bedrock; reported In 1910 only, but may also have been carried on in other years. Gold may have come from quartz veins in schist near head of creek. Concentrates contalned gold, clanabar, and platinumgroup metale.

Cepps, 1911 (B 480), p. 221-222, 224 -- Preliminary to B 501.

Capps, 1912 (B 501), p. 44 -- Mining, 1910.

p. 46 - Two canyons in schist ridges; rest of courge in gravel sand, and 21gnite. Colors found in many parts of basin. Mining In 1910 was $5 \mathrm{ml}$. above Rex $\mathrm{Cr}$; gravels $6 \mathrm{ft}$. deep on Bchist bedrock.

Maddren, 1918 (B 662), p. 380-381 -- Three basins separated by rldges of schlat chrough wh1ch creek has cut canyons hundreds of feet deep. Has been min1ng where creek enters canyon between middle aid lower bagins.

p. 383 -- In 1910 two men trted mining at head of canyon between middle and lower basins ( $5 \mathrm{ml}$. above mouth of Rex $C r$. ). Stream gravels about $6 \mathrm{ft}$. deep on schist, but too lean for hand mining. Quartz velns in schise at head of creek may have been source of gold.

Joesting, 1942 (TDM 1), p. 20 -- Platinum has been found in placers. p. 27 -- Scarce cinnabar in placers.

Malone, 1962 (IC 8131), p. 56 -- Scarce placer cinnabar.

Malone, 1965 (IC 8252), p. 54 -- Placer cinnabar.

Cobb, 1973 (B 1374), p. 111 -- Concentrates contain gold, clnnabar, and platinum-group metals. 
Camp BIId

Falrbanks district
Gold (?)

Falrbanks $(14.85,15.45)$

$64^{\circ} 52^{\prime} \mathrm{N}, 148^{\circ} 01^{\prime} \mathrm{W}$

Sumary: Vein; no data other than on attlude and operators.

Chapman and Foster, 1969 (P 625-D), P. D18 -- Veln strikes MNE and dips $85^{\circ} \omega$. 
(Carsbou Cr., trib. Callfornia Cr.) Ant1mony, Tungsten

Bonnifield district

Falrbanks $(9.8,1.25)$

MF $-410,100.41$

$64^{\circ} 04^{\prime} \mathrm{N}, 248^{\circ} 43^{\prime} \mathrm{W}$

Sumary: Stiontte-bearting quarcz veln; wolframite in float.

Joesting, 1942 (TDM 1), p. 12 - Stibnite veln has been gtaked several t1mes.

p. 41 -- Wolframle (ferber1te) has been found In float.

Berg and Cobb, 1967 (B 1246), p. 202-203 -- St1bn1te-bearing quartz veln.

24 
(Cartbou Cr., trib. Dry Cr.) Gold

Bontifield district Ealrbanks (20.8, 1.5) spprox. MF $-410,10 \mathrm{C} .84 \quad 64^{\circ} 04^{\prime} \mathrm{N}, 147^{\circ} 18^{\prime} \mathrm{W}$ approx.

Sumary: Stream flows on hlgh gravels and schlot. Small-scale minting In 1909.

CappB, 1911 (B 480), p. 229 - Preliminary to B 501.

Capps, 1912 (B 501), P. 52 - Flows through valley that is in high gravels at head and in achist in lower part. Two men made wages minting gtream gravels in 1909, but did not xeturn ln 1910. 
Cllpper

Falrbanka d1strict

MF $-410,10 \mathrm{c} .14$
AntImony, Gold

Fa1rbanks $(14.85,15.55)$

$64^{\circ} 52^{\prime} \mathrm{N}, 148^{\circ} 00^{\prime} \mathrm{W}$

Sumary: Tunnel $500 \mathrm{ft}$. long follows small faulted quartz veln in schlst. Stibnite, antimony sulfosalt (Jamesontte?), and free gold are present. May have been very small production of stibnite; reference (K113een and Mertie, 1951) not consiatent. Sttbntte ore in alght not more than one ton.

H111, 1933 (B 849-B), P. 152 - Tunnel $237 \mathrm{ft}$. Long In blot1te sch1st wth gome quarczlte. A narrow flsgure (strike $N 20^{\circ} \mathrm{W}$, dip $85^{\circ} \mathrm{W}$ ) near portal is 1-8 1n. wide and carries a ldrtle sulfide and free gold (about $\$ 12$ per ton). Other flssures do not appear to be mineralized.

Kllleen and Mertle, 1951 (OF 42), p. 12 -- Ore sample contained $56.58 \%$ $\mathrm{Sb}$.

p. 14 - Mnor amount of attbntte has been mined.

p. 16 - Winding tunnel 500 ft. long follows small faulted vertical quartz veln. "Sulphantimonltes are present as crystals disseriated in the vein quartz." Lens of stibnite partially exposed in tunnel 1s 2-12 $\mathrm{in}$. thick, $3 \mathrm{ft}$. wide, and may be 10-15 ft. long. Sauple contalned $56.58 \% \mathrm{Sb}$ -

p. 43 - - Ore in sight not more than 1 ton.

Chapman and Fotter, 1969 (P 625-D), P. D18 -- References to B 849-B and OF 42. IAdditional sources are cited, but no other information appears to have been taken from them.] 
(Cody Cr.)

Bonniffeld distict
Gold (?)

Fa1rbanks $(7.75,1.0)$ approx. $64^{\circ} 03^{\prime} \mathrm{N}, 149^{\circ} 00^{\prime} \mathrm{W}$ approx.

Sumary: Placer gold reported. See also Rambler.

Maddren, 1918 (B 662), p. 368 -- Placer gold reported. No mining in 1916. Source msy be lodes such as one in basin that carries stibnite [Rambler]. 
Colbert

Ealrbanks district

$M F-410,10 \mathrm{c} .32$
Tungsten

Falrbanks $(19.6,17.6)$

$64^{\circ} 59^{\prime} \mathrm{N}, 147^{\circ} 22^{\prime} \mathrm{W}$

Summary: Calcareous layers (and probably a little limestone) 10 quartz mlca schist replaced by scheelite ore. Garnet tactite contalns no scheelite. Lode traced (by trenchlng) for 2,000 ft. on surface; pinched out in some places; $50 \mathrm{ft}$. wide in one trench. Scheelite abundant in 3 ore shoots and in small (less than $1 \mathrm{ft.}$ ) pockets. Average tenor of ore shoots is $1.3 \% \mathrm{WO}_{3}$ over average width of $1.6 \mathrm{ft}$.

Joesting, 1943 (TDM 2), p. 22-23 -- Prospecting 1941-42. Scheelitebearing flost traced to bedrock source.

Thorne and others, 1948 (RI 4174), P. 4 -- USBM exploration project was completed in 1943.

p. 6 -- Prospect 1,200 ft. south of and parallel to Cleary

H11l ore zone,

p. 8-11 -- Located, 1941. Trenches and p1ts traced mineralIzed structure more than $1,000 \mathrm{ft}$; geophysical exploration ind 1 cated "a continuous vela structure for over 3,000 ft." Property comprises 14 unpatented claims $n$ Bedrock schists (metasedimentary rocks), 1ntruded by porphyritic gran1te. Scheelite mineralization generally parallels ochistosity; small amounts of disseminated scheelite in granite. Ore lenses occupy parts of a thin (about 30 $f t$. thick) limestone bed in the schist; 2 perlods of silicification. Scheel1te lenses are 0.5 to $1.2 \mathrm{ft}$. thick and from a few to $100 \mathrm{ft}$. long; $\mathrm{WO}_{3}$ content $151.2 \%$ to $2.5 \%$. Quartz veirlets and thin fractures that carry scheelite are in the ore zone, commonly parallel to main teplacement zone.

p. 13-15 -- Deta11s of USBM exploration project.

Byers, 1957 (B 1024-I), p. 189 -- Lode formed by replacement of calcareous layers in country rock (mainly quartz-mica schist); strike about $\mathrm{N} 70^{\circ} \mathrm{E}$ and $\mathrm{d} I \mathrm{p}$ about $35^{\circ} \mathrm{N}$. About $0.4 \mathrm{ml}$. $\mathrm{N}$ of main mass of porphyritic granite and $0.8 \mathrm{ml}$. S of an outlying cupola.

p. 199-200 - Lade traced by trenching for 2,000 ft. Thickness Is varlable; pinched out in some places and $50 \mathrm{ft}$. wide in one trench. Ore mainly replaced calcareous achist rather than limestone (as at Stepovich mine), although some remant 11mestone is present; no scheelite in a garnet tactlte on property. Scheelite abundant in 3 ore shoots and in wldely spaced small (less than $1 \mathrm{ft.}$ ) pockets; scattered gralos also. Average tenor of ore shoots $181.3 \%$ WO 3 over an average width of $1.6 \mathrm{ft}$.

Berg and Cobb, 1967 (B 1246), p. 220 - Lode 1,000 ft. south of, parallel to, and sioilar to stepovich lode.

Chapman and Foster, 1969 (P 625-D), P. D16 - Reference to B 1024-I, P. 199-200. 
Columb1a

Falrbanks distrlct

MF-410, 10c. 29
Tungsten

Fa1rbanks $(18.5,17.0)$

$64^{\circ} 57^{\prime} \mathrm{N}, 147^{\circ} 31^{\prime} \mathrm{W}$

Summary: Lode 18 schist contalning quartz-gcheelite stringers; porphyrittc granfte hanging wall. Old workings consisted of 2 shafts, 2 adits, pit, trenches. No production reported.

Mertle, 1918 (B 662), P. 422-423-- Along wegtern pertphery of large mass of porphyritlc grante. Tunnel $130 \mathrm{ft}$. long; $3-\mathrm{ft}$. zone of scheelite-bearing rock with porphyritic granite hanging wall; strikes $\mathrm{N} 20^{\circ} \mathrm{W}$, dips $30^{\circ} \mathrm{E}$. Open cut exposes scheellte lode cut by $1-f t$. quartz vein; much wad assoctated with quartz.

Chapin, 1919 (B 692), p. 326 -- Adit driven $80 \mathrm{ft}$. along scheelitebearing quartz veln with grantte hanging wall.

Thorme and others, 1948 (RI 4174), P. 24-25 -- Quotations from B 662 .

Byers, 1957 (B 1024-I), P. 201 - Had been located by summer of 1916.

p. 205-206 -- Workings in 1932 consisted of 2 adits, 2 shatts, a $p 1 t$, and 4 trenches; all caved. In 1916 an adit was driven $80 \mathrm{ft}$. along a $3-\mathrm{ft}$. zone of schist containing quartzscheeltte stringers; strike $\mathrm{N} 20^{\circ} \mathrm{W}$, dip $30^{\circ} \mathrm{E}$; porphyrttic grantte hanglag wall. Pleces of quartz-mlca schlat cut by scheelitebearing quartz on dump in 1943.

Berg and Cobb, 1967 (B 1246), P. 220 - On ridge between Steele and First Chance Creeks where the scheelite depostts are in tactite, s1l1cated limestone, grante and pegmatitic dikes, and small quartz velns in schist.

Chapman and Foster, 1969 (P 625-D), p. D16 -- References to B 692, P. 326, and $B$ 1024-I, P. 205-206.

Mulligan, 1974 (IC 8626), P. 13 - From P 625-D, P. D16. 
(Columb1a CE.)

Falrbanks district
Gold (?)

Fa1rbanks $(18.2,16.25)$

$64^{\circ} 54^{\prime} \mathrm{N}, 147^{\circ} 33^{\prime} \mathrm{W}$

Sumary: Low-grade free-milling quartz reported.

Sutth, 1913 (B 525), p. 210 -- Ad1t reported to have been driven $100 \mathrm{ft}$. on a quartz lead. Ore sald to be low grade but free mliling. Not violted by Sitth.

Soutth, 1913 (B 542), p. 196 -- Same ar B 525. 
Cottonblossom

Falrbanks district

MF-410, 10c. 5
Antimony, Gold

Fa1rbanks $(14.45,15.3)$

$64^{\circ} 52^{\prime} \mathrm{N}, 14 \mathrm{~B}^{\circ} 04^{\prime} \mathrm{W}$

Sumary: Mineralized zone near a fault plane contalns bunches of stibnite and gold and stibnite in quartz veins. Two shafts (70 $\mathrm{ft}$. and $60 \mathrm{ft}$. deep) and about $100 \mathrm{ft}$. of other workings. No record of production. Iricludes reference to 5t. Jude.

Smtth, 1913 (B 525), P. 208-209 -- Gouge above a fault plane and smal1 fracture and quartz stringers, some of which contain gold. St1bnite occurs in bunches and sparingly in quartz stringers. Many cavities left by decomposition of sulfides. Explored by 2 shafts (70 ft. and $60 \mathrm{ft}$. deep).

Smlth, 1913 (B 542), P. 194-195 -. Same as B 525.

Chap In, 1914 (B 592), p. 352 -- $100 \mathrm{Et}$. of tunnel and crosscuts in mineralized area cut small stringers, but no defintte lode.

Brooks, 1916 (B 649), p. 40 -- Quotation from B 525.

H111, 1933 (B 849-B), p. 123 -. Two old ghafta Indicate that vein strikes $\mathrm{N} 35^{\circ}$ W. Dump consists of dark mlca schlst and very little quartz.

Rt1leen and Mertle, 1951 (OF 42), p. 20 -- Reference to B 525.

Chapman and Foster, 1969 (P 625-D), P. D19 -- References to B 525, B 592, B $849-B$, OF 42. 
(Crlpple Cx.)

Falrbanks district

MF-410, 10c. 45
GoId, $\operatorname{Tin}$

Fa1rbanks (14.9-15.5, 14.8-15.25) $64^{\circ} 50^{\circ}-64^{\circ} 51^{\prime} \mathrm{N}, 147^{\circ} 55^{\prime}-148^{\circ} 00^{\prime} \mathrm{W}$

Sumary: Bedrock malnly tica schlst. In early days (1908-23) most (1f not al1) production was from benches. Some of ground as much as $100 \mathrm{ft}$. deep. Preparations for large-scale dredgling begun In 1936; dredge began operating in 1940. Rare cassiterite has been reporced from placers.

Brooks, 1907 (B 314), p. 36 -- Gold values found, 1906.

Brooks, 1908 (B 345), p. 42 -- Carries gold. Only bench clatms a mile below Ester Cr, have been productive (1907).

Prindle, 1908 (B 337), P. 29 -- Quotation Erom B 314.

p. 44-45 - Bedrock princtpally wdea schist. Bench depogits east of creek being mined in 1907.

Ellsworth, 1910 (B 442), p. 234 -- Some production, 1909.

Ellsworth, 1912 (B 520), p. 243 -- No minting in 1911.

El1sworth and Davenport, 1913 (B 542), P. 208 -- Good prospects found, but no mining., 1912.

Prtadle and Katz, 1913 (B 525), p. 110 -- Depth to bedrock on one cla1m is $76-100 \mathrm{ft}$.

p. 112-113 -- Production, 1908-10, worth $\$ 50,000$. Gold worth $\$ 17.18$ per oz.

Chap1n, 1914 (B 592), p. 360 -- M1ning, 1913.

Smith, 1938 (B 897-A), p. 46-48 -- Work preparatory to large-scale dredgIng, 1936.

Silth, 1939 (B 910-A), p. 46-47 -- Work preparatory to large-8cale dredg1ng, 1937.

Smlth, 1939 (B 917-A), p. 44-45 -- Work prepararory to largenscale dredg1ng, 1938.

Smlth, 1941 (B 926-A), p. 40-41 -- Work preparatory to large-scale dredgIng, 1939.

Joest1ng, 1942 (TDM 1), p. 32 -- Rare placer cassiterite.

Sintth, 1942 (B 933-A), p. 38-40, 67 - New, large dredge began operating, 1940. Artificlal freeztng used to atabilize banks of thawed mater1al. 
Crown Point

Fa1rbanks dietrict

M $-410,10 c .19$
Gold

Falrbanks $(15.0,15.2)$

$64^{\circ} 51^{\prime} \mathrm{N}, 148^{\circ} 00^{\circ} \mathrm{W}$

Summary: Vlalble gold tn narrow quartz velns in jolnts in chloritic schlst. Gouge along one veln wall and schlst altered to clay. Wall rock ald to contaln a little gold. Explored by Inclined shaft $20 \mathrm{ft}$. long.

Chapin, 1914 (B 592), P. 353 -- Inclined shaft driven 20 ft. along 2 narrow (2 in. and $1 / 2$ 1n.) quartz velns in parallel joints in schist. Velns atrike $\mathbb{N} 40^{\circ} \mathrm{W}$ and $\mathrm{d} d \mathrm{p} 65^{\circ} \mathrm{SW}$ and are separated by $4 \mathrm{ft}$. of chlorttic sch1st. Gouge along hanging wall of larger vein; adjoining schlst altered to clay. Specks of vistble gold in quartz; wall rock sald to contain a little gold.

Chapman and Foster, 1969 (P 625-D), P. D17 - Reference to B 592. 
(Danlel (s) Cr.)

Bonntfleld dietrict MF $-410,10 \mathrm{C} .72$
Gold

Fa1rbanks (11.15-11.25, 1.75-1.85)

$64^{\circ} 06^{\prime} \mathrm{N}, 148^{\circ} 32^{\prime}-148^{\circ} 33^{\circ} \mathrm{W}$

Summary: Stream heads in schist and has cut through Nenana Gravel and coal-bearing rocks (both Tertlary) into underlyling gchist, though gravel has slumped into creek in places. Gold to flne and rounded. Sporad1c small-scale mining from 1914 to 1921 and in 1928-29.

Maddren, 1918 B. 662), p. 388-391 -- Stream (about 4 mi. Iong) heads 10 schiat. In middle and lower parts of stream course bedrock is slighty consolidated coal-bearing rocks overlain by Nenana Gravel; for 2 miles above mouth stream has cut down into underlying sch1st. Placer cla1m staked in 1905; mining began in 1914. On clatms near mouth Nenana Gravel overlies echlst and has olumped into creek canyon. Gold fine and rounded. Maddren thinks gold was derived from local sources in schtst; no particular evidence for such a source.

Mart1n, 1920 (B 712), p. 44 -- Mining, 1918.

Brooks, 1922 (B 722), P. 51 - M1ning, 1920.

Brooks, 1923 (B 739), P. $35-$ Mintng, 1921.

Sw1th, 1930 (B 813), p. 35 -- Mining, 1928; product1on no more than 8 few hundred dollars.

Smtth, 1932 (B B24), p. 40 - Mining (amali-scale), 1929. 
Dorothy \& Dortce

Falrbanks d1otrict

MF $-410,10 \mathrm{c} .14$
Artimony, Gold (?)

Falrbanks (14.85, 15.55)

$64^{\circ} 53^{\prime} \mathrm{N}, 148^{\circ} 00^{\prime} \mathrm{W}$

Sumary: Veln atriklng $N 40^{\circ} \mathrm{E}$ and explored by a shaft of unknown depth may carry gold. Stibnlte float was not traced to source. Includes references to: Coggrove Krutsch, Krutsch and Coggrove.

Chap in, 1914 (B 592), p. 354 - Lode strikes $N 40^{\circ}$ E. Opentags Ishaft on Index map] caved in 1913.

Joesting, 1942 (IDM 1), p. II - stlbnite float, some pleces 2 ft. across. Stibnite is coarse and bladed. Several bulldozed trenchea, but bedrock source not found. (Krutsch and Cosgrove.)

K11leen and Mert1e, 1951 (OF 42), P. 19 -- Reference to TDM 1.

P. 42 - Showling of stibnite of unproven significance.

Chapman and Foster, 1969 (P 625-D), P. D18 -- References to B 592 and TOM 1. 
(Eagle Cr.)

Bonnifleld diatrict

$M F-410,105.42$
Ant1mony

Falrbanks $(10.4,1.2)$

$64^{\circ} 04^{\prime} \mathrm{N}, 148^{\circ} 39^{\circ} \mathrm{W}$

Sumary: High-grade bladed atibnte float on rldge. No development reported.

Joesting, 1942 (TDM 1), p, 12 -- Antimony prospect has been staked; no work reported.

Joegt1ng, 1943 (TDM2), p. 13-14 - on rldge between Eagle and Lynx Creeks. H1gh-grade coarse, bladed stlonite float scactered for 100 ft. long ridge. Covered by clatm of Strand \& Miebold.

Berg and Cobb, 1967 (B 1246), p. 202-203 - Small st1brite lode(s). 
Summary: Mica schlst country rock. Arsay of grab sample of materlal in ore bin in 1931 (when worktngs were inaccessible) showed value of $\$ 8.64$ per ton. Dump was matnly mica schlst and vein quartz. Exploratory work began 1926; production in 1928. Idle during mogt of 1929 and 19,30-35. Production reported, 1937-39 and posstbly 1n 1940. Includes references to Happy Creek, Nickaloff.

Sinth, 2929 (8 797), p. I3 - Began exploratory work, 1926; purchased an old $m 131$ and 1nstalled $1 \mathrm{t}$.

Solth, 1930 (B 810), p. 15 -- Development work, 1927.

Sinth, 1930 (B 813), p. 1 )- Produced, 1928.

Sntth, 1932 (B 824), p. 20 -. Idle during most of 1929 season; owners squabbiting.

Hx11, 1933 (B 849-B), P. 150 - Workings (shaft and tunnel) caved in June, 1931. Vein appears to strike $N 25^{\circ}-30^{\circ} \mathrm{E}$. Rock on dump is mica schlst with considerable veln quartz. Grab sample of marertal left in are bin assayed $\$ 8.64$ per ton.

Smith, 1933 (8 836), P. 19 - I81e, 1930.

Solth, 1934 (B 864-A), P. 20 - Idle, 1933.

Smtth, 1938 (B 897-A), P. 22 - Prospect1ng or development, 1936.

Smith, 1939 (B 910-A), P. 25 -- Product1ve mintng and custom miling, 1937.

Smlth, 1941 (B 926-A), P. 23 -- Product10n, 1939.

Smith, 1942 (B 933-A), p. 23 -- Development (posstbly also production), 1940.

Chapman and Foster, 1969 (P 625-D), p. D17 - Quartz veins In mica schist. Has been gold production. 
(Eurous Cr.)

Falrbanke district MF-410, 10c. 43
Gold (?)

Falrbonks (14.1, 14.7) approx. $64^{\circ} 50^{\prime} \mathrm{N}, 148^{\circ} 06^{\prime} \mathrm{W}$ approx.

Summary: May have been a liftle mining in 1910.

EIlsworth and Parker, 1911 (B 480), p. 258 - Very l1ttle actual mintng in 1910. 
Engineer

Fairbanks district

$M F-410,10 c .24$
Gold

Fairbanks $(17.7,16.6)$

$64^{\circ} 55^{\circ} \mathrm{N}, 147^{\circ} 38^{\prime} \mathrm{W}$

Summary: Iron-stalned quartz contains arsenopyrite. Assay of grab sample showed value of $\$ 2.86$ per ton.

H111, 1933 (B 849-B), P. 153 -- Two parallel veins strike $N 70^{\circ} \mathrm{E}$. Iron-stalned quartz with arsenopyrite. Grab sample assayed $\$ 2.86$ per ton.

Chapman and Foster, 1969 (P 625-D), P. D16 -- Reference to B 849-B.

3 
(Englneer $\mathrm{Cr}$, )

Fatrbanke diatrict

MF -410 , 10c. 53
Gold

Fa1rbanks $(17.45-17.9,17.45-17.8)$

$64^{\circ} 50^{\prime}-64^{\circ} 51^{\prime} \mathrm{N}, 147^{\circ} 35^{\prime}-147^{\circ} 40^{\prime} \mathrm{W}$

Sumary: Depth to bedrock from about $50 \mathrm{ft}$. to more than $100 \mathrm{ft}$. Gold in basal 4-7 ft. of gravel, much of which was derived from grante. Placer mining reported in most years from 1907 to 1916. Later mining (malnly dredging) was probably with that on Goldstream.

Prindle, 1908 (B 337), P. 39, 41 -- Gold has been found and some produced.

Prindle and Katz, 1909 (B 379), P. 190-191 - Preliminary to B 525.

Ellsworth, 1910 (B 442), P. 230, 232 - Minlng, 1909. Some very IIch cla1ms located.

Ellsworth and Parker, 1911 (B 480), p. 154-155 -- Mining, 1910.

Elisworth, 1912 (B 520), p. 241 -- Large-scale mintng, 1911.

El18worth and Davenport, 1913 (B 542), p. 206 - Mintng, 1912; great decrease from pace of 1911.

Prindle and Katz, 2913 (\$ 525), p. 105-106 -- M1ning, 1908. Depth to bedrock 50-100 ft.; values in 4-7 tt. of gravel over widths of 30-100 ft. are 1-6 dollars per bedrock foot. Granlte in valley; gravel near bedrock largely dertved from grante.

p. 110-111 $\rightarrow$ Depth to bedrock 49-103 ft. Production from Englneer Cr. and tributaries, 1907-10, worth $\$ 1,800,000$.

P. 113 rold worth $\$ 18.70$ per oz.

Brooks, 1914 (B 592), p. 68 -- M1ntog, 1913.

Chap1n, 1914 (B 592), P. 359 -- Mintog, 1913.

Eaktn, 1915 (B 622), P. 234 - Mintng, 1914.

Smltr, 1917 (BMB 153), p. 51 - MInIng, 1916.

Sutth, 1933 (B 844-A), p. 33 -- Falrbanks Exploration Co. acquired an extensive tract of placer gromd, 1931. Experiment with underground. slutcing was terminated because of heaving of floor of drift. 
(Ester Cr.)

Fairbanks district

MF-410, 10C. 44
Antimony, Gold, Tungsten

Fa1rbanks (14.3-14.95, 14.85-15.1)

$64^{\circ} 50^{\prime}-64^{\circ} 51^{\prime} \mathrm{N}, 147^{\circ} 59^{\prime}-148^{\circ} 05^{\prime} \mathrm{W}$

Sumbary: Placer deposits (both stream and bench) deeply burled; bedrock Eloor between Ester and Crlpple Creeks nearly flat. Mined from 1905 to 1963; dredged from 1937 on. Stibnite and scheelite in concentrates. Includes references to (Esther $\mathrm{Cr}$.); see also (Cripple Cr.).

Prindle, 1906 (B 284), p. 119-120 - Gold deposits deeply (25-135 ft.) buried; probably not related to present stream course.

Brooks, 1907 (B 314), p. 30 - Stibntte found in placers. p. $36-$ Mining, 1906.

Brooks, 1908 (B 345), p. 41-42 -- A major producer in 1907. New discovery on bench east of creek.

Prindle, 1908 (B 337), p. 29 -- Quotation from B 314.

p. 44-45 -- Bedrock principally mica schist; some granite. Depth to bedrock $4 \mathrm{mi}$. above mouth is $15 \mathrm{ft}$; at mouth is 120-135 ft. Some terrace gravels. 5-6 ft. of gravel and weathered bedrock are mined; 4-6 dollars per cu. yd.

Prindle and Katz, 1909 (B 379), p. 190, 192, 195, 197, 199-200 -- Pre1iminary to $B 525$ and general data on mining methods.

Ellsworth, 1910 (B 442), P. 233-234 - Mining, 1909. Some of the richer clatms were mined out.

Brooks, 1911 (P 70), P. 182 -- Mining, 1908.

Ellsworth and Parker, 1911 (B 480), P. 157-158 - Mining, 1910. Prospectlag may have discovered an old chanael 1,500 ft. from present pay streak.

Ellsworth, 1912 (B 520), p. 243 -- M1ning, 1911; output declined.

EIlsworth and Davenport, 1913 (B 542), p. 209 -- Mining, 1912. Output estimated at $\$ 300,000$.

Prindle and Katz, 1913 (B 525), P. 103-105 - Staked in 1903, product1on begun in 1905. Alluvlal deposits deep, bedrock floor between Ester and Crlpple Creeks nearly flat; terrain irregularities due to different thtcknesses of flll. Productive gravels average $300 \mathrm{ft}$. wlde, less than $100 \mathrm{ft}$. deep, $8 \mathrm{ft}$. thick; average $\$ 1.50$ per bedrock foot. Bench between Ester and Ready Bullion Creeks is auriferous. posits).

p. 110 -- Depth to bedrock 18-170 ft. (stream and bench de-

p. 112-113 -- Production, 1904-10, worth $\$ 7,800,000$. Gold worth $\$ 16.56$ per oz.

Brooks, 1914 (B 592), p. 68 -- Mining, 1913.

Chapla, 1914 (B 592), p. 359 - Sumer slulcing curtalled by shortage of water.

Brooks, 1915 (B 622), P. 54 -- Production from Ester Cr. and tributarles through 1914 was worth about $\$ 10,300,000$.

Eak1a, 1915 (B 622), p. 234-235 -- Mining, 1914. 
(Ester $\left.C_{r}\right)$ - Continued

Brooks, 1916 (B 642), p. 58-59 -- Through 1915 production from Ester Cx. and tributaries was worth about $\$ 10,680,000$. Mining, 1915 .

Sm1th, 1917 (BMB 142), p. 23 -- Mining, 1915.

Sm1th, 1917 (BMB 153), p. 51 -- M1n1ng, 1916.

Brooks, 1918 (B 662); P. 51 -- Through 1916 production from Ester Cr. and tributarles was worth about $\$ 10,960,000$.

p. 54 -- Mining, 1916.

Mart1n, 1919 (B 692), p. 35 -- Through 1917 production from Ester Cr. and tributaries was worth about $\$ 11,230,000$.

Mart1n, 1920 (B.712), p. 39 -- Through 1918 production from Ester Cr. and tributaries was worth about $\$ 11,280,000$.

Brooks and Mart10, 1921 (B 714), p. 81 - Through 1919 production from Ester $C r$. and tributarles was worth about $\$ 11,330,000$.

Brooks, 1922 (B 722), p. 45 -. Production 1903-20, from Ester Cr, and tributarles was worth about $\$ 11,359,000$.

Brooks, 1923 (B 739), p. 29 - Product1on, 1903-21, from Ester and adjacent creeks was worth about $\$ 11,394,000$.

Brooks and Capps, 1924 (B 755), p. 35 -n Production, 1903-22, from Ester and adjacent creeks was worth about $\$ 11,443,000$.

Capps, 1924 (B 755), p. 146 -- A major producing stream of the district. Brooks, 1925 (B 773), P. 45 - Product1ons 1903-23, from Ester and adjacent creeks was worth about $\$ 11,497,000$.

Smith, 1926 (B 783), p. 13 m- Product1on, 1903-24, from Ester and adjacent creeks was worth about $\$ 11,600,000$.

Moff1t, 1927 (B 792), P. 17 -- Mining, 1925.

Sm1th, 1929 (B 797), p. 20 -- M1ning, 1926.

Sintth, 1930 (B 810), p. 25 -- Mining, 1927.

Smlth, 1930 (B 813), p. 28 -- Mining, 1928.

Smlth, 1932 (B 824), p. 33 -- M1ning, 1929.

Smlth, 1933 (B 836), p. 33 -- M1ning, 1930.

Smith, 1933 (B 844-A), p. 32 -- Mining, 1931.

Sm1th, 1934 (B 857-A), P. 30 -- Mining, 1932.

Smlth, 1934 (B 864-A), P. 35 -- M1n1ng, 1933; exploration and preparatory work.

Smtth, 1936 (B 868-A), P. 36 -- M1ning and preparatory work, 1934.

Smtth, 1937 (B 880-A), p. 39-40 - Mining and preparatory work, 1935.

Smlth, 1938 (B 897-A), p. 46-47 - Mining and preparatory work, 1936.

Smlth, 1939 (B 910-A), p. 46-47, 76 -- Dredging, 1937; also preparatory work.

Smlth, 1939 (B 917-A), p. 43-45, 74 -- Dredging and preparatory work, 1938.

Smtth, 1940 (B 926-A), P. 40-41, 70 - Dredging and preparatory work, 1939.

Joestlog, 1942 (TDM 1), P. $39--$ Scarce placer scheellte.

Smith, 1942 (B 933-A), P. 38,67-Dredging, 1940.

K1leen and Mertie, 1951 (OF 42), p. 7 -- Stibnite In placer concentrates.

Wedow, Kllleen, and others, 1954 (C 331), p. 6 -- Windrows of dredge tallIngs consplcuous in valley bottom.

Byers, 1957 (B I024-I), p. 188 -- Scheelfte 1n placer concentrates.

Burand, 1966 (GC 10), P. 2 -- Productive from 1904 to late 1963, when dredge was shut down. 
(Ester Cr.) - Continued

Koschmann and Bergendahl, 1968 (P 610), p. 26 -- Huge reserves of aurdferous gravels were dredged.

Cobb. 1973 (B 1374), P. 128-229-- Produced gold worth [much] more than $\$ 4,000,000$ (at 20.67 per oz.). 
(Eva Cr., Bonnifield dist.)

Bonnifield district

MF-410, Loc. 65
Gold, Tungsten

Falrbanks $(9.05-9.55,0.9-1.0)$

$64^{\circ} 03^{\prime} \mathrm{N}, 148^{\circ} 46^{\prime}-148^{\circ} 50^{\prime} \mathrm{W}$

Summary: Upper valley In Nenana Gravel; lower $1-1 / 2 \mathrm{ml}$. In underly Ing schibt. Gravels in schlor area are auriferous. Float near Liberty Bell mine contalns gold, blamuth, and sulfides. Gold in placers probably derived from Liberty Bell and simliar lodes. Placer concentrates contaln gold, wolframlte, and scheelite. Minting reported for 1916, 1920-21, 1933-38, 1940; no data on amount of production. See also Liberty Bell.

Maddren, 1918 (B 662), p. 381 -- Mintng, 1916.

p. 384-386 - Stream rloes on gravel-capped ridge and flows $5 \mathrm{ml}$. to Callforala $\mathrm{Cr}$. Upper valley cut in high gravels INenana Grave1]; lower $1-1 / 2 \mathrm{ml}$. In underlying Bchlot. Gravels in schtot area contain gold. At lode area [L1berty Bell mine] schist float contalns gold, native bismuth, arsenopyrite, and other sulf1des. Placer gold probably dertved from this and simllar lodes in schist. About a quarter mile above mouth of W1lson Cr. stream gravels were being mined in 1916.

Brooks, 1922 (B 722), p. 51 - Mining, 1920. Brooks, 1923 (B 739), p. 35 - Mtntog, 1921. Smlth, 1934 (o 864-A), p. 42 -- Mining, 1933. Smlth, 1936 (B 868-A), p. 44 - Mining, 1934.

Smlth, 1937 (B 880-A), P. 46 -n Smal1-scale mining, 1935.

5outh, 1938 (B 897-A), p. 56 -- Mining, 1936.

Sulth, 1939 (B 910-A), P. 55 - Mining, 1937.

Sutth, 1939 (B 917-A), p. 54 - Mtning, 1938.

Joesting, 1942 (TDM 1), P. 39 - Scarce wolframte and rare Bcheeltte in placers.

p. 41 - Holframte (ferberlte) In placer concentrates near Liberty Bell mine.

Smtth, 1942 (B 933-A), p. 48 -- M1ning (w1th s "one-bucket dredge"), 1940. Joesting, 1943 (TDM 2), P. 20 -- Scarce placer scheelice. Thorne and others, 1948 (RI 4174), p. 27 - quotation from TDM 2. Cobb, 1973 (B 1374), P. 111 -- Scheelite in concentrates. 
(Eva $C_{T}$, FaIrbanks dist.)

Fairbanks district $M-410$, loco. 44
Gold

Fairbanks. (14.85-14.95, 15.1-15.2)

$64^{\circ} 51^{\prime} \mathrm{N}, 1^{\prime} 48^{\circ} 00^{\prime} \mathrm{W}$

Summary: Placer gold minting or prospecting, 1911-15. No data on total production; about 24,000 fine oz. recovered in 1912. Mining near mouth may have been reported for Ester $\mathrm{Cr}$. Many lode prospects on ridge E of Eva $C r$.

Ellsworth, 1912 (B 520), p. 243 -- Rich gravel reported to have been Found, 1911 .

Ellsworth and Davenport, 1913 (B 542), P. 209 - Production to 1912 worth about half a million dollars.

Chap tn, 1914 (B 592), p. 359 -- Mining, 1913.

Eakin, 1915 (B 622), p. 235 - Prospecting, 1914. Dtyinting rod used to locate one shaft.

Brooks, 1916 (B 642), p. 59 - Mining, 1915.

45 
Eve Quartz Co.

Falrbanks district

MF-410, 10c. 19
GoId

Fadrbanks $(15.0,15.3)$ approx. $64^{\circ} 52^{\prime} \mathrm{N}, 148^{\circ} 00^{\prime} \mathrm{W}$ approx.

Sumary: Mining in 1928 reported. Eva Quartz Co. could have been minting on part of elther Ryan or Stay properties.

Smlth, 1930 (B 813), p. 17 -- Mining, 1928. [Part of Ryan or Stay properttes.] 
Fatr Chance

Falrbanks distriet

$\mathrm{MF}-410,10 \mathrm{C}, 17$
Go1d

Fairbanks (14.95, 15.55)

$64^{\circ} 52^{\prime} \mathrm{N}, 148^{\circ} 00^{\prime} \mathrm{W}$

Sumbry: Mineralized zone of crushed schiot, quartzite, and quartz mixed with blue gouge; conslderable free gold. Developed by shafts, drffts, and a stope. Total production (mainly rich quartz ore) worth about $\$ 2,000$. Mineralized zone appear6 to extend onto nelghboring Blue Bdrd clatm. Includes reference to Blue Blrd clatm of Milier o'Connor.

Chaptn, 1914 (B 592), p. 353-354 - Mineral1zed zone is a mass of crushed schtst and quartzice, considerable quartz crushed and mlxed with blue gouge, all contalning constderable free gold. Zone dipg steeply to SE. Opened by shaft, 2 levels $(40 \mathrm{ft}$, and $18 \mathrm{ft.})$, and a small stope that may be in another ore body. Main mineralized zone cur off by fault (strlke $\mathrm{N} 30^{\circ} \mathrm{E}$, dip $70^{\circ} \mathrm{SE}$ ) on $40 \mathrm{ft}$. level.

Eakin, 1915 (B 622), P. 237 -- Mining, 1914.

H111, 1933 (B 849-B), P. 139 - 3 shafts about $50 \mathrm{ft}$, apart. 40 tons ore mined in 1930 and milled with disappoint1ng regults; crushed mixture of gouge, schlst and quartz, a sample of whych assayed $\$ 5.95$ per ton. Mineralized zone atrlkes $\mathrm{N} 20^{\circ} \mathrm{E}$, dtps $60^{\circ} \mathrm{W}$; several velns of quartz ore in cruahed schlst; $\$ 1,800$ in gold recovered from quartz. On nearby Blue Btrd clatm tunnel was driven fn 1931 to Intergect what is probably the same zone as is on Falr Chance group. Chapman and Foster, 1969 (P 625-D), P. D17 -. References to B 592 and $849-B$. 
Falrbanks district

Eafrbanks (14.55, 15.55)

MF -410 , 10c. 9

$64^{\circ} 53^{\prime} \mathrm{N}, 148^{\circ} 03^{\prime} \mathrm{W}$

Sumary: Quartz veln, crushed schist, and fault breccla contalns visible gold and sulfides (mainly pyrite). Gold has been produced, but venture was abandoned because regults were discouraging. 60 foot-long inclined shaft and other worktngs.

Swlth, 1913 (B 525), p. 198 - North-trend1ng apparentiy lent1cular veln in schist dips $40^{\circ} \mathrm{E}$; cut by many small faulis; sulfides (mafnly pyrtee) and visible gold. Inclined shaft $15 \mathrm{ft}$. deep.

Solth, 1913 (B 542), p. $184-$ Same as B 525.

Chapin, 1914 (B 592), p. 352 - Inclined shaft sunk $60 \mathrm{ft}$. on veln, but work was abandoned because results were not encouraging.

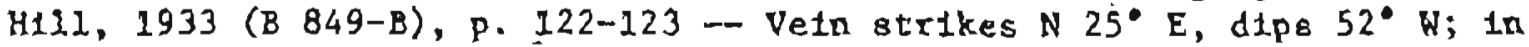
schist; $4 \mathrm{ln}$. of quartz, $14 \mathrm{in}$. crushed schist, $2 \mathrm{ft}$. 1ron-stained fault brecclo of eragments of achist and quartz. Sample from a p111ar asgayed $\$ 7.06$ per ton. Good ore reportediy mined and milled in the past. Most worktngs caved in 1931.

Chapman and Foster, 1969 (P 625-D), P. 019 - References to B 849-B and more data on names of past operators. 
Eirgt Chance

Fairbanks district

MF-410, 10c. 14
Go1d

Palrbanks (14.85, 15.55$)$

$64^{\circ} 52^{\prime} \mathrm{N}, 148^{\circ} 00^{\prime} \mathrm{W}$

Summary: Vein averaged one foot thick in mined area. Shaft $120 \mathrm{fr}$. deep. 520.tons of ore above 100-ft. level was stoped out; gave returns of $\$ 26,000$ in gold, probably all between 1924 and 1928.

Smlth, 1926 (8 783), p. 8-9 -- Ore wl13ed, 1924.

Moff1t, 1927 (B 792), p. 12 - Shaft $40 \mathrm{ft}$. deep and a short dr1ft expose 2-3 ft. thick. 43 tons ore taken for m111 test, 1925.

Salth, 1930 (B 813), p. 17 - M1ning, 1928.

H111, 1933 (B 849-B), p. 147-148 - VeIn at surface strikes $\mathrm{N} 10^{\circ} \mathrm{E}$, dips $44^{\circ} W$, $186 \mathrm{In}$. to $4 \mathrm{ft}$. wlde (average in stoped area $12 \mathrm{ln}$ ). Wall rock schlst. Shaft $120 \mathrm{ft}$. deep; all ore above 100-ft. level norchward to a fault $70 \mathrm{Et}$. from shaft was stoped out. 520 tons of ore ylelded g018 worth $\$ 26,000$. Dre south of ghaft lower grade (less than $\$ 20$ per ton below 100-ft. level).

Chapman and Fogter, 1969 (P 62S-D), P. D18 -- Reference to B B49-B. 
(FIrst Chance Cr., trib. Goldstream Cr.) Gold, Tin, Tungsten

Falrbanks district

Fa1rbanks $(17.8-18.1,17.05-17.2)$

$M F-410,10 c, 53$

$64^{\circ} 57^{\prime}-64^{\circ} 58^{\prime} \mathrm{N}, 147^{\circ} 34^{\prime}-147^{\circ} 35^{\prime} \mathrm{W}$

Summary: Gold reported as early as 1908 and a recently as 1940 . Some of ground mined was as much as $42 \mathrm{ft}$. deep. Abundant placer scheelite derlved from lodes at head of creek; clogged some sluice-box riffles. Cassiterite rare in concentrates.

Prindle and Ratz, 1909 (B 379), p. 194 -- Mining, 1908.

Ellsworth, 1912 (B 520), p. 241 -- M1ning, 1911.

Ellsworth and Davenport, 1913 (B 542), p. $206--$ Mining, 1912. Some of ground about $35 \mathrm{Et}$. deep.

Prindle and Katz, 1913 (B 525), p. 113 -- Gold worth \$18.25 per oz.

Chap1r, 1914 (B 592), p. 358 -- Mining, 1913. 42 ft. to bedrock; paystreak $4 \mathrm{tt}$. wide.

Eakin, 1915 (B 622), P. 234 -- Mining, 1914.

Sw1th, 1917 (BMB 142), p. 23 -- Mining, 1915.

Swtth, 1939 (B 917 A ), p. 43 - Mining, 1938.

Sulth, 1941 (B 926-A), P. 40 - Mining, 1939.

Joesting, 1942 (TDM 1), P. 32 -- Rare placer cassiterite.

p. 39-41 -- Placer scheelite abundant. Scheelite occurs near head of creek in contact-metamorphosed limestone and in gold-bearIng quartz velns near porphyrit1c grantte intrusive body. On lower part of creek scheelite constitutes main part of placer concentrates; clogs sluice-box riffles.

Smlth, 1942 (B 933-A), p. 39 -- Mintng, 1940.

Byers, 1957 (B 1024-I), P. 188 -- Scheellte in placer concentrates.

p. 210-211 -- Scheelite came from nearby lodes. 
Flagler

Fatrbanks district
Go1d (?)

Fałrbanks $(34.5,15.7)$ approx. $64^{\circ} 53^{\prime} \mathrm{N}, 148^{\circ} 03^{\prime} \mathrm{W}$ approx.

Sumbry: Quartz veln; no defintte tatement that gold 1 s present. Only assessment work.

Solth, 1913 (B 525), p. 197-198-- Open cut and 1nclined shaft $12 \mathrm{ft}$. deep on large body of mineralized quartz of probably low tenor. Vein trends North and dipo $45^{\circ} \mathrm{E}$. Nearby, lens-shaped masses of quattz have been broken up and scattered about. TThese prospects are not named in the text, but are shown as Flagler on f1g. 20, p. 204.]

Smith, 1913 (B 542), P. 183-184 - Same as B 525.

Chap 1n, 1914 (B 592), P. 352 - Only agsessment work has been done as of 1913.

Chapman and Foster, 1969 (P 625-D), P. DL9 -- References to B 525, B 592. 
Flower

Falrbanks diatrfet

MF-410, 10c. 15

\section{Gold (?)}

Fa1rbanke $(14.85,15.4)$

$64^{\circ} 53^{\prime} \mathrm{N}, 148^{\circ} 00^{\prime} \mathrm{W}$

Summary: Vertical veln was explored nomettme before 1931 by shallow shafts and a short tunnel. No other data. May be the same occurrence as little Flower; actitudes of velns as reported at the two occurrences differ.

H111, 1933 (B 849-B), P. 152 -- Vertlcal veln strikes N 10 E. Several shallow shafts and a ohort tunnel (caved in 1931). 
(Flume Cr.)

Falrbanks digtrict

MF-410, 10C. 54
Gold

Fa1rbanks $(18.2-18.3,17.8-17.85)$ $65^{\circ} 00^{\prime} \mathrm{N}, 147^{\circ} 32^{\circ} \mathrm{W}$

Sumary: Has been placer mining. Probably was nomally reported with that on Pedro Cr.

Brook日, 1916 (B 642), P. S9-M1ning, 1915.

Chapman and Foster, 1969 (P 625-D), P1. 2 - Area shown as having been placer mined: 
(Fourth of July $C x_{1}$ )

Bonnifleld diatict

$M F-410,100,73$
Antlmony, Gold, Lead, Stlver

Fa1rbanks (11.1-11.2, 0.8-1.15)

$64^{\circ} 02^{\prime}-64^{\circ} 03^{\prime} \mathrm{N}, 148^{\circ} 33^{\circ} \mathrm{W}$

Sumary: Bedrock Bchlgt; dike crosses creek.1 mi. above mouth. All placer gold below dike. This creek was probably an tmportant contrlbutor of gold to Totatlantka $C r$. Sample of Jamesontte (?) float (bedrock source not found) contained $0.08 \mathrm{oz}$. gold and 94.8 oz. stlver per ton, $25.3 \%$ antimony, $25.6 \%$ lead.

Maddren, 1916 (B-662), P. 388 -- One of major producing creeks In Totaclantka basin.

p. 393-394 - Valley eroded in schlst; lower half mile Inclsed 100-150 ft. Dike [kInd of rock not stated] crosses creek about $1 / 4$ mt. above mouth. All gold in creek downstream from dlke; no gold noted in dike or schlst near 1t. Gold rough, some with a arcached quartz; largest nugget worth about $\$ 25.00$. Most of minting in 191011; production worth about $\$ 10,000$. Creek may have been an 1mportant aource of gold in Totatlantka $\mathrm{Cr}$.

Overbeck, 1916 (B 662), P. 351 -- "A mineralized zone that apparently is gold bearing ts reported from Fourth of July Creek about half a otle above "1CB mouth."

Joesting, 1943 (TDM 2), P. 13-14 -- Fine-gralned Jamegontte (?) Float. In bedrock a 6-1n. zone of gouge and quartz is barren. Plcked float eample contained $0.08 \mathrm{oz}$. Au and $94.8 \mathrm{oz}$. Ag per ton, 15.3\% Sb, and $25.6 \% \mathrm{~Pb}$. Occurrence has been ataked. 
Falrbanko district

Fairbanks $(16.6,17.0)$

$64^{\circ} 57^{\prime} \mathrm{N}, 147^{\circ} 46^{\prime} \mathrm{W}$

Sumary: Lens of impure magnesian limestone in schist. Lens is ft. thlck; can be traced more than $300 \mathrm{ft}$. on surface; dips $35^{\circ}$.

War1ng, 1947 (C 18), p. 6, 8-9 -- Lens of wh1te, fine-grained limestone exposed for $200 \mathrm{ft}$; maximum thickness $15 \mathrm{ft}$. Too much magnesia (19.88\%) for use as burnened lime.

Rutledge and others, 1953 (RI 4932), P. 120-121 -- Small lens of 11mestone in Blich Creek Schist. Strikes $\mathrm{E}$, dips $35^{\circ} \mathrm{W}$, is $15 \mathrm{ft}$. thick and can be traced more than $300 \mathrm{ft}$. along base of h111 on which 1t crops out. Analysis shows $29.9 \% \mathrm{CaO}, 19.6 \% \mathrm{MgO}, 26.2 \%$ $\mathrm{S}_{1} \mathrm{O}_{2}, 0.4 \% \mathrm{Al}_{2} \mathrm{O}_{3}, 0.3 \% \mathrm{Fe}_{2} \mathrm{O}_{3}$. 
(Fox Cr.)

Fatrbanks diatrict

MF-410, loc. 52
Gold, Tungsten

Fairbanks (17.6, 17.4-17.8)

$64^{\circ} 59^{\prime}-65^{\circ} 00^{\prime} \mathrm{N}, 347^{\circ} 37^{\prime}-147^{\circ} 38^{\prime} \mathrm{W}$

Sumary: Placer gold mined sporadically from as early as 1908 to as recently os 1926; gravels 6-19 ft. deep; hand methods only. Much scheellte (estrmated $90 \%$ of concentrates) near head of creek. Granite at head of creek. Lode near mouth has been prospected for gold.

Prindle, 1908 (B 337), P. 39, 41 - Gold has been found and wined. Prindle and Kati, 1909 (B 379), p. 191 an Depth to bedrock 10-19 ft. P. 193 -- Mining, 1908.

Ellsworth, 1910 (B 442), p. 232 -- Mining, 1909.

Prindle and Katz, 1913 (B 525), p. 105-106 -- Mining, 1908. Granite near head of creek.

p. 111 - Production, 1905-10, worth $\$ 31,000$.

P. 113 - Gold worth $\$ 17.50$ per oz.

Smith, 1913 (B 525), p. 198 - Gold lode has been prospected near mouth.

Sm1th, 1913 (B 542), p. 184 -- Same as B 525, P. 198.

Sm1th, 1929 (B 797), p. 20 - Mining, 1926.

Joest1ng, 1943 (TDM 2), p. 20 -a Abundant placer scheelite.

p. 24 - Scheelfte safd to have been found in placer cut near head of creek; placer concentrates from nearby mainly acheelite. p. 28 -- Placer scheelite particularly abundant on upper Fox Cr.

Thorne and others, 1948 (RI 4174), p. 28-29 - Quotations from TDM 2. Byers, 1957 (B 1024-I), P. 188 -- Scheel1te in placer concentrates.

P. 210 -- Placer concentrates near head of creek contalned an estimated $90 \%$ scheelite.

Kul11gan, 1974 (IC 8626), p. 13 - Deposit 6-8 ft. deep; worked sporadically by hand methods. Considerable scheelite recovered with gold near head of creek. 
Frank11n

Faltbanks district

MF $-410,10 \mathrm{c}, 32$

\section{Tungaten}

Fa1rbanke (19.6, 17.6) approx. $64^{\circ} 59^{\prime} \mathrm{N}, 147^{\circ} 23^{\prime} \mathrm{W}$ approx.

Sumary: Scheelite 1 n quartz and sllicates that replaced Ifmy horlaons In schlat. See also Ptaxmigan.

Chap 1n, 1919 (B 692), p. 327 -- Several mineralized zonea that atrike $\mathrm{N} 40^{\circ} \mathrm{W}$ and dip $\mathrm{NW}$; one appears to be 15-20 ft. across. Lode material 18 quartz and silicate rock that presumably selectively replaced itmestone. Scheelite occurs In quartz and silicates. Chapman and Footer, 1969 (P 625-D), P. D16 -- Reference to B 692. Here itmestone is considered to be itmy horizons in schist. 
Gale

Fafrbanks distict
Gold (?)

Pa1rbanks $(14.5,15.1)$

$64^{\circ} 51^{\prime} \mathrm{N}, 148^{\circ} 04^{\prime} \mathrm{W}$

Summory: Iron-stalned quartz and brown-weathering schtst reported to be aur1ferous. Prospect p1t $20 \mathrm{ft}$. deep.

Smith, 1913 (B 525), p. 206 - Prospect p1t sunk 20 ft. On Iron-sta1ned quartz and brown-weatherling schlst. Quartz appears.to be in small otringers in ochlst, but large pleces were seen on dump. Reported to carry some gold. INot aamed in text; shown ag Gale on E1g. 20, p. 204.]

Smith, 1913 (B 542), P. 192 -- Same as B 525.

Chapman and Foster, 1969 (P 625-D), P. D19 -- Reference to B S2S. 
YGilmore Cr.)

Fa1rbanks district

MF- $410,10 c .55$
Bismuth, Gold, Tungsten

Fa1rbanics $(18.25-19.05,17.5-17.6)$ $64^{\circ} 59^{\prime} \mathrm{N}, 147^{\circ} 26^{\prime}-147^{\circ} 32^{\prime} \mathrm{W}$

Sumbery: Granttic rocks and area with lode echeelite occurrences in contact-metamorphosed limestone and gold-bearing quartz velas near head. Gravels (stream and bench) as much as $60 \mathrm{ft}$. deep. Mined from 2905 to as recently as 1940. Dredge tallings now in lower valley. Concentrates contained bismuth, some intergrown with gold, and scheelite.

Prindle, 1906 (B 284), P. 115 - Blsmuth "In close association with the gold in a nugget..."

p. 118 -- Depasics from a few feet near head to $60 \mathrm{ft}$. thick at mouth. Gold, some with intergrown native bismuth, on or da bedrock.

Prindle, 1908 (B 337), P. 39-40 -- Joins Pedro Cr. to form Goldstream. Gravel is malnly schist, quartz, and granite. Bench on north; aurlferous gravels; in some placers is separated from valley floor by rock rim. Nuggets worth up to $\$ 20$. Some b1smuth with the gold.

Prindle and Katz, 1909 (B 370), p. 192 - Depth to bedrock 4 18 ft. p. 194 -- Mining, 1908.

Ellsworth, 1910 (B 442), p. 232 - Mining, 1909.

El1sworth and Parker, 1911 (B 480), p. 154-155 -- Mining, 1910.

Ellsworth, 1912 (B 520), p. 241 - Mining, 1911.

Ellsworth and Davenport, 1913 (B 542), p. 206 - Mining, 1912.

Prindle and Katz, 1913 (B 525), p. 105-106 -- Mining, 1908. Deposits shallow. Native bismuth intergrown with gold.

p. 109 -- Depth to bedrock 8-18 ft.

P. 111 -- Production, 1905-10, worch $\$ 121,200$.

P. 113 - Gold worth $\$ 18.85$ per $0 z$.

Chapln, 1914 (B 592), p. 359 -- M1ning, 1913.

Eakin, 1915 (B 622), p. 234 - Mlning, 1914.

Brooks, 1916 (B 642), p. 59 -- Mtning, 1915.

Smith, 1917 (BMB 142), p. 23 -- Mining, 1915.

Smith, 1917 (BMB 153), p. 51 -- M1ning, 1916; production worth about $\$ 40,000$.

Brooks, 1918 (B 662), p. 54 - Mining, 1916.

H111, 1933 (B 849 B), P. 71 - Blsmuth In placer concentrate; nearly surrounded a small gold nugget.

Smlth, 1938 (B 897-A), p. 46 -- Mialng, 1936.

Smith, 1939 (B 910-A), p. 46 -- M1ning, 1937.

Smith, 1939 (B 917-A), p. 43-46 -- Mining, 1938.

Silth, 1941 (B 926-A), P. 40, 42 -- Mining, 1939.

Joesting, 1942 (TOM 1), p. 39-40-- Placer scheeltte comon. Creek drains area with lode scheelite w contact-metamorphosed 11mestone and gold-bearing quartz velns near porphyritlc grante intrusive body.

Sm1th, 1942 (B 933-A), P. 39 -- Mining, 1940. 
(GIlmore Cr.) - Continued

Wedow, K1lleen, and others, 1954 (C 331), P. 6 -- Windrows of dredge tallings consplcuous in valley battom.

Wedow, White, and others, 1954 (C 335), P. 1--Reference to B 849-B, p. 71.

Byers, 1957 (B 1024-I), P. 188 -- Scheelite In concentrates.

p. 210-211 -- Scheel1te locally derlved. 
(Gold King Cr.)

Bonnifleld district

$M F-410$, locs. 80-82
Goid. Tunbsten

Fa1rbanke $(15.2-15.35,0.8-2.2)$

$64^{\circ} 02^{\prime}-64^{\circ} 06^{\prime} \mathrm{N}, 148^{\circ} 00^{\prime}-148^{\circ} 02^{\prime} \mathrm{W}$

Sumary: Stream rloes on high ridge of gchlgt, but most of courge ts cut in Tertlary hlgh gravels (Nenana Gravel) and coal-bearing rocks. Bedrock in areas mined malnly clay. Gold probably reconcentrated from Nenena Grave1. Scheelite in concentrates. Atcempts at large-scale mining of Nenena Gravel were not successful. Mining reported intermittently from 1903 to as recently as 1940. Includes references to (Gold $\mathrm{Run}(\mathrm{Cr}$.$) ).$

Prindle, 1907 (B 314), P. 212 - Clay bedrock where mining is 1n progress (1906); boulders act as rffeles. Gold elther in 4-5 Et. of gravel or on clay bedrock; probably derlved from high gravels.

Brooks, 1910 (B 442), p. 44 - Minlag, 1909; hydraulic plant belng 1nstalled.

Brooks, 1911 (P 70), P. 174 - Same as B 314.

Capps, 1911 (B 480), P. 221-222, 226-228 -- Prellminaty to B 501.

Capps, 1912 (B 501), p. 44 -n Mlaing in 1910.

P. 49-5I - Rises on high ridge of schist; Elows for 10 onl. through high gravels in valley inclsed $1,200-1,500 \mathrm{ft}$. below gravel surface. Stream gravels mined since 1903. Ground 2-8 ft. deep; many large boulders. Gold elther th gravels or on soft clayey bedrock. High gravels are auriferous. In 1910 there were extensive preparations for large-scale hydraulicking of high gravels (to begin in 1911); Inadequate advance prospecting.

Maddren, 1918 (B 662), p. 400-401 - Large-scale operation described in B 501 wexe abandoned after a short trlal run. Reworked stream gravels on clay bedrock were belng wined in 1916. Creek has eroded about to the base of the Nenana Gravel.

Capps, 1924 (B 755), p. 138 -- Atcempt at large-scale hydraulic mining of Nenana Gravel was not EInanclally successful.

Smith, 1930 (B 813), P. 35 -- Small-scale mining on Gold Run Cr., 1928. Smlth, 1932 (B 824), p. 40 - Small-scale wining on Gold Run $C_{r}, 1929$. Mofftt, 1933 (B 836), p. 345 -- Mining, 1930.

Smith, 1933 (B 836), p. 41 - Mining, 1930.

Sulth, 1933 (B 844-A), p. 41 -- Mining on Gold Run, 1931.

Smith, 1934 (B 857-A), p. 38 -- Minigg, 1932.

Sinth, 1934 (B B64-A), P. 42 -- Mining, 1933.

Smith, 1936 (B 868-A), P. 44 -- Mining, 1934.

Sretth, 1937 (B 880-A), P. 46 - Hydraulic mining, 1935.

Joesting, 1942 (TDM 1), P. 39 -- Rare placer scheellte.

Sm1th, 2942 (B 933 A), p. 48-40 - Minlng, 1940.

Koschmann and BergendahI, 1968 (P 610), p. 24 - First mining in distr1ct, 1903.

Cobb, 1973 (B 1374), p. 111 -- Scheellte in concentrates. 
(Goldstrean (Cr.))

Falrbanks district

MF- $410,10 \mathrm{c} .53$
Go1d, T1n, Tungsten

Foirbanke (17.1-18.2, 36.8 17.5)

$64^{\circ} 56^{\prime}-64^{\circ} 59^{\prime} \mathrm{N}, 147^{\circ} 32^{\prime}-147^{\circ} 42^{\prime} \mathrm{W}$

Summary: Stream formed by confluence of Gllmore and Pedro Creeks. Most of gravel in valley deep ( 30 or more feet); both stream and bench placers. Mined by non-dredge methods, 1903-27; dredges from 1928 to as recently as 1940 . Cassiterlte (source not known) and scheelfte (from nearby lodes) in concentrates.

Prindle, 1905 (B 251), p. 75 - Clalms worked in 1903-04. p. 77 - Ground 30 or more feet deep. Not much active development in 1904.

Prindle, 1906 (B 284), p. 118-119 -- Depos1ts deep. Very 11ttle development as of 1905 .

Brooks, 1907 (B 314), p. 36-37 -- Mining, 1906. Some new, rich discoveries.

Brooks, 1908 (B 345), P. 41 -N New discovery on lower part of creek, 1907. Prindle, 1908 (B 337), p. 29 quotation from B 314.

p. 38-39-n Alluvium up to $200 \mathrm{ft}$. thick. As of 1907 minlang was on upper 17 claims. Iimit of profitable mining was $\$ 1.50-\$ 2.00$ per yard.

Prindle and Katz, 1909 (B 379), p. 190, 195 -- MLaIng, 1908.

p. 191 - Depth to bedrock 22-70 ft.

E1lsworth, 1910 (B 442), p. 232 - Mining, I909.

Brooks, 1911 (P 70), P. 182 - Mining, 1908.

Ellsworth and Parker, 1911 (B 480), P. 154-155 - Mining, 1910. Bench clalms had richer pay streak than creek bed.

Ellsworth, 1912 (B 520), p. 240-24I - Lergest producer in district, $1910-11$.

Ellsworth and Davenport, 1913 (B 542), p. 205-206 - A ma10r producer, 1912.

Prindle and Katz, 1913 (B 525), p. 105 -- Mining, 1908. From confluence of Pedro and Gilwore Creeks to clatm 27 below. Course of productive ground diverges from that of creek. Productive ground sverages 6 it. thick, $225 \mathrm{ft}$. wide, \$1 per bedrock foot.

p. 109-Ill -- Depth to bedrock (Including bench clalms) is 14-

$110 \mathrm{ft}$. Production, 1903-10, worth $\$ 4,249,500$.

P. $113 \sim$ Gold worth $\$ 18.33$ per oz.

Brooks, 1914 (B 592), p. 68-- Mining, 1913.

Chapin, 1914 (B 592), p. 358 -- One of major producers in district, 1913.

Brooks, 1915 (B 622), p. 54-55 - Production from Goldstream and 1ts tributaries through 1914 was worth about $\$ 12,400,000$. Mining, 1914.

Brooks, 1916 (B 642), p. 58-59-- Through 1915 production from Goldstream and eributaries was worth about $\$ 13,050,000$. Mining, 1915.

Solch, 1917 (BMB 142), p. 23 -- M1ning, 1915.

Sm1th, 1917 (BMB 153), P. S1 -- Mintag, 1916.

Brooks, 1918 (B 662), p. 51 - Through 1916 production Erom Goldstream and Its tributartes was worth about $\$ 13,500,000$.

p. 54 - Mining, 1916 . 
(Goldstream $\left.\left(C_{.}\right)\right)$- Continued

Mart1n, 1919 (B 692), p. 35 - Through 1917 production from Goldstrearo and 1 te tributaries was worth about $\$ 13,800,000$.

Mart1n, 1920 (B 732), p. 39 - Through 1918 production from Goldstream and 1 ts tributaries was worth about $\$ 14,080,000$.

Brooks and Martin, 1921 (B 714), P. 80-81-- Mining, 1919, on Goldstream and tributaries produced gold worth about $\$ 275,000$; total, 1903-19. about $\$ 14,355,000$.

Brooks, 1922 (B 722), p. 44-45 -- Mining, 1920, on Goldstream and tributarles; total production, 1903-20, was worth about $\$ 14,625,000$.

Brooks, 1923 (B 739), p. 29 - Mining, 1921, In Goldgtream basin; total production, 1903-21, was worth about $\$ 14,836,000$.

Brooks and Capps, 1924 (B 755), p. 35 . Mining, 1922, in Goldstream basin; total production, 1903-22, was worth about $\$ 15,085,000$.

Capps, 1924 (B 755), P. 146 - Has been one of the major producing streams in the district.

Brooks, 1925 (B 773), P. 45 -- Production, 1903-23, from Goldstream basin was worth about $\$ 15,286,000$.

Smith, 1926 (B 783), p. 13 -- Production, 1903-24, from Goldstream bastn was worth about $\$ 15,512,000$.

Moff1t, 1927 (B 792), p. 14, 17 - Stripping, test dr11ling, and ditch buxlding, 1925.

Smith, 1929 (8 797), P. 19 -- Water being brought from Chatanika R: near Fa1th $\mathrm{Cr}$. [C1rcle quad.], 1926.

Smith, 1930 (B 810), p. 25 -- Thawing preparatory to dredging, 1927.

Smith, 1930 (B 813), p. 28, 47 -- Dredge began operating, 1928.

Smith, 1932 (B B24), P. 32-33, 52 -- Dredge operated, 1929.

Sm1th, 1933 (B 836), P. 32-33, 54 -- Dredge operated, 1930.

Smith, 1933 (B 844-A), p. 32-33, 54 -- Dredge operated, 1931.

Silth, 1934 (B 857-A), p. 30-31, S1 - Dredge operated, 1932.

Smith, 1934 (B 864-A), p. 34-35, 56-- Mining, Including dredg1ng, 1933.

Solth, 1936 (B 868-A), P. 35-36, 58 -- Mining, lncluding dredg1ng, 1934.

Smith, 1937 (B 880-A), p. 39-40, 61 -- Miniag, 1ncluding dredging, 1935:

Swith, 1938 (B 897-A), p. 46-47,71-- Mining, Including dredglng, 1936.

Soith, 1939 (B 910-A), p. 46-47, 76 -- Dredging, 1937.

Solth, 1939 (B 917-A), p. 43-46, 74 -- Mlning, 1ncluding dredging, 1938.

Solth, 1941 (B 926-A), p. 40-42, 70 -- Mining, lncluding dredging, 1939.

Joest1ng, 1942 (TDM 1), p. 32 -- Scarce placex cassiterite.

p. 39 -- Scarce placer scheelite.

Smith, 1942 (B 933-A), P. 38-39, 67-Mining, lncluding dredging, 1940.

Wedow, Killeen, and others, 1954 (C 331), p. 6 -- Windrows of dredge tallings consplcuous in valley bottom.

Byers, 1957 (B 1024-I), p. 188 -- Scheelite in concentrates.

p. 210-211 -- Scheel1te from lodes nearby

Cobb, 1973 (B 1374), p. 128-129 -- One of major producing creeks of distract; gold worth [several times] more than $\$ 4,000,000$ (gold at $\$ 20.67$ per oz.).

Mul11gan, I974 (IC 8626), p. 14 -- Burled, frozen placer adjacent to dredge tallings; ground patented; no recent mining. 
Goodw1n

Falrbanks distict

MF $-410,10 c .23$
Gold

Falrbanks $(17.1,17.7)$

$65^{\circ} 00^{\prime} \mathrm{N}, 147^{\circ} 42^{\prime} \mathrm{W}$

Sumary: Zone of brecciated 1ron atained schiot (vein quartz in mater1 al on dwoms) containg a Ilttle gold. See albo Bunker Hill.

H1I1, 1933 (B 849-B), p. 153-154 - Tunnel (caved In 1931) crosscut a 50-ft. w1de zone of brecclated 1ron-stained schtst that strikes $\mathrm{N} 70^{\circ} \mathrm{E}$ and $1 \mathrm{~s}$ vertical. Materlal on dump contains vein quartz. Grab sample assayed only 23 cente per ton.

Chapman and Fogter, 1969 (P 625-D), P. D15 - [Called Bunker H111 prospect.] Reference to B 849-B. 
Grant, near Happy Cr.

Falrbanks district

MF-410, 10c. 21
Go1d

Falrbanks $(15.25,15.7)$

$64^{\circ} 53^{\prime} \mathrm{N}, 147^{\circ} 58^{\prime} \mathrm{W}$

Sumary: Vein 5 -6 ft. thick (2-4 ft. quartz) discovered at bottom of placer proppect shaft. As of 1931 there were $250 \mathrm{ft}$. of drifts on 2 levels and 500-600 tons of ore that returned \$15-\$20 per ton had been mined. Mining in 193.7 reported. Includes references to Irishman.

Smith, 1932 (B 824), p. 20 -w Lode mineralization found at bottom of ald shaft sunk for placer prospecting, 1929.

H111, 1933 (B 849-B), p. 150-151 - Old placer prospect shafe h1t quartz veln in bedrock. Shaft was continued to total depth of $240 \mathrm{ft}$. $280 \mathrm{ft}$. of dxifes on 200-ft, and 240-ft. levels. Veln sald to strike $N 40^{\circ} \mathrm{E}, \operatorname{dip} 65^{\circ} \mathrm{E}$, and be 5-6 ft, wide, including 2-4 ft. quartz. S00-600 tons of ore from this veln was inflied and ylelded $\$ 15$ to $\$ 20$ per ton. Mine not accessible because of bad alr at time of H1Il's visit (June 1931).

Swith, 1933 (B 836), p. 19 -- Quartz with disseminated sulfides mined and sacked at mine, 1930.

Smlth, 1939 (B 910-A), p. 25 - Gold produced, 1937.

KIlleen and Mert1e, 1951 (OF 42), P. 19-- Reference to B 836, P. 19.

Chapman and Foster, 1969 (P 625-D), P. DIJ - Data from above references. Also: quartz veln characterized by crushed and recemented silica; gouge probably on gently dipping thrusts [probably from Vaiv. of Alaska BS thesis]. [The authorg' no's. 136 and 137 are the same mine.] 
Falibanko dietrict

MF-410, 10c. 30
Falrbanke $(18.6,17.2)$

$64^{\circ} 58^{\prime} \mathrm{N}, 147^{\circ} 30^{\prime} \mathrm{W}$

Sumbary: Brecclated schlat contains gmall quartz veins and gouge seam. Free gold can be panned from cruahed rock. Nearby quartz veln $1515 \mathrm{ft}$. wide.

Chap $1 n, 1914$ (B 592), p. 345-346 -- Small open cut on quartz ve1n at least $15 \mathrm{ft}$. across. Tunnel atarted to crosscut veln intersected brecclated thass of schtst with small quartz velns and gouge seams between blocks. Free gold can be panned from crushed rock.

Chapran and Foster, 1969 (P 625-D), P. D16 -- Reference to B 692.

Mull1gan, 1974 (IC 8626), p. 13 -- "A 15-foot-w1de quartz vein near a brecclated mass of ochist contalns sparse gold in quartz." 
(Grubstake Cr.)

Bonntfield district

$M E-410$, locs. $77-79$
Gold, Mercury, Tungsten

Fa1rbanks (13.75-14.5, 0.4-0.8)

$64^{\circ} 00^{\prime}-64^{\circ} 02^{\prime} \mathrm{N}, 148^{\circ} 09^{\prime}-148^{\circ} 13^{\prime} \mathrm{W}$

Sumary: Most of course in coal-bearlng rocks or Nenana Gravel. Gold In basal 2.ft. of stream gravels; probably reconcentrated from Nenana Gravel. Small amounts of cinnabar and scheelite in concentrates. Intermittent mining, 1905 to as recently as 1940.

Prindle, 1907 (B 314), p. 210-211 -- Bedrock 1s at1cky clay, sand, and coal. Gravel up to 6 ft. thick and made up of schist, quartzite, vein quartz, and other reststant rock types. Gold, in sma1l, worn, Elat pleces, in basal $2 \mathrm{ft}$. of gravel or on clay bedrock. Mining, 1905-06.

Brooks, 1910 (B 442), P. $44--$ Mining, 1909.

Brooks, 1911 (P 70), P. 173-174 -. Same as 314.

Capps, 1911 (B 480), p. 221-222, 225 - - Preliminary to B 501.

Capps, 1912 (B 501), p. 44 -- Mining, 1910.

p. 48 - M Mning since 1905. Follows contact between sch1st and high gravel. Mined near mouth where stream has cut into coalbearing rocks.

Maddren, 1918 (B 662), p. 399-400 -- M1ning, 1916; has been major producer in Tatlanika basin since discovery in 1905 . Rises on ridge of Nenana Gravel; lower course In coal-bearlng rocks. Gold in $2 \mathrm{ft}$. of stream gravel on bedrock of coal-bearing formation. Gold probably reconcentrated from Nenana Gravel.

Brooks, 1923 (B 739), P. 35 -- Mining, 1921.

Swlth, 1930 (B 813), p. 35 -- Mining (5-man camp), 1928.

Solth, 1932 (B 824), p. 40 -- Mining (5-man camp), 1929.

Moff1t, 1933 (B 836), p. 345 -- Minling, 1930.

Sutth, 1933 (B 836), p. 41 -- Minting, 1930.

Sm1th, 1937 (B 880-A); p. 46 -- Small-scale mining, 1935.

Smlth, 1941 (B 926-A), P. 51 -- Mining, 1939.

Joesting, 1942 (TDM L), p. 27 -- Scarce placer cinnabar.

p. 39 -- Rare placer scheelite.

Smith, 1942 (8 933-A), p. 48-49 - Mining, 1940.

Malone, 1962 (IC 8131), p. 56 -- Scarce placer clnnabar.

Malone, 1965 (IC 8252), p. 55 -- Placer clnnabar.

Cobb, 1973 (B 1374), p. 112 - Scheellte and cinnabar in placer concentrates. 


\section{(Happy Cr.)}

Ealrbanks district

$M F-410$, Ioc. 48

\section{Gold}

Fa1rbenks (15.1, 15.8) approx. $64^{\circ} 53^{\prime} \mathrm{N}, 147^{\circ} 59^{\prime} \mathrm{W}$ approx.

Summary: Gold placer mining, 1913 -16, 1938-40. Some ground as deep as $140 \mathrm{ft}$. See also Dorothy \& Dorice.

Brooks, 1914 (8 592), p, 68 -- Min1ng, 1913. New discovery made. Chapin, 1914 (B 592), p. 360 -- New productive ground found, 1913. Eakin, 1915 (B 622), p. 235 -- Mining, 1914. Brooks, 1916 (B 642), p. 59 -- M1ning, 1915.

Smith, 1917 (BMB 142), p. 23 -- Mining, 1915; new ground found at depth of $140 \mathrm{ft}$.

Sm1th, 1917 (BMB 153), p. 51 -- Mining, 1916.

Smlth, 1939 (B 917-A), p. 43 -.. Mining, 1938.

Swith, 1941 (B 926 A), p. 40 -. Mining, 1939.

Sto1th, 1942 (B 933-A), p. 39 -. Mining, 1940. 
(hearat Cr.)

Bonnifield district MF-410, 1oc. 75

\section{Gold}

Fatrbank (33.85, 1.7) approx. $64^{\circ} 05^{\prime} \mathrm{N}, 148^{\circ} 12^{\prime} \mathrm{W}$ approx.

Sumary: Rises in high gravel (Nenane Gravel); In lower part of course has cut down 1nto underlyling coal-bearing rocks, on whtch are stream gravels in whtch gold has been reconcentrated from Nenana Gravel. A few thousand dollars worth of gold recovered in 2905.

Prindle, 1907 (8 314), p. 211 -- Flows in coalmbearling formation. A few thousand dollars recovered in 1905 from point $2 \mathrm{ml}$. above mouth. Prospecting in 1906.

Brooks, 1911 (P 70), p. 173-174 -- Same as B 314.

Capps, 1911 (B 480), p. 226 -- Prelimlnary to B 501.

Capps, 1912 (B S01), p. 49 -. In coal-beartng series. No mindng 101910. Maddren, 1918 (B 662), p. 399-400 -- Has not been very productive. SImxlar to Grubstake and Roosevelt Creeks. Rises in Nenana Cravel and has cut down 1nto underlying coal-bearing formation. Gold in stream gravels on bedrock of coal-bearing formation; probably reconcentrated from Nenana Gravel. 
Regan \& Lefebre

Falrbanks district

\section{Gold (?)}

Falrbanks (14.95, 15.1) approx. $64^{\circ} 51^{\prime} \mathrm{N}, 148^{\circ} 00^{\prime} \mathrm{W}$ approx.

Summary: Tunnel driven on veln. No data on gold tenor.

Sm1th, 1913 (B 525), p. 207 -- Tunnel driven on northmicending veln. No statement of tenor. Crose-cutting fracture zone with broken country rock and quartz exposed in runnel.

Smlth, 1913 (B 542), P. 193 - Same as B 525. 
Hegs o Thomas

Falrbanks district
Gold (?)

Fafrbanks $(14.75,15.25)$

$64^{\circ} 52^{\prime} \mathrm{N}, 148^{\circ} 02^{\prime \prime} \mathrm{W}$

Sumary: Chloritlc gchlst cut by small quartz velns. No data on gold content (if any). See aloo Prometheus.

Smtth, 1913 (8 525), p. 208 - Decomposed chlorftic sch1st cut by amall quartz veins. No data on posolble wetall1c content.

Solth, 1913 (B 542), P. 194 -- Same as B 525. 


\section{(H11l Cr.)}

Fatrbanks district MF-410, 10c. 56
Gold

Fairbanks $(19.05,17.35-17.55)$ $64^{\circ} 58^{\prime}-64^{\circ} 59^{\prime} \mathrm{N}, 147^{\circ} 26^{\prime} \mathrm{W}$

Sumary: Eluvial placer developed on and in weathered grante of a stock; gold derfved from a oftnerallzed zone near the contact between granite and schist.

Prindle, 1908 (B 337), p. 40 -- R1ses in granlice dome; most of courae 1n granlte. Open cut on narrow pay streak near contact between grante and 8 ch1st.

Brooks, 1911 (B 480), P. 69 -. Placers appear to have been derived from minerallzed zone around a granite stock.

Brooks, 1925 (B 773), p. 19 -- Elurval placer developed on and in weachered grantee. Placer not rich like those in Iditarod district. 
(Homestake Cr.)

Bonntfleld diatrict

MF $-410,10 \mathrm{c} .74$
Gold

Fa1rbanke (11.15-11.25, 0.1-0.3) $64^{\circ} 00^{\prime} \mathrm{N}, 148^{\circ} 31^{\prime}-148^{\circ} 32^{\prime} \mathrm{W}$

Surmary: Stream cuts through a ridge of Bchlst intruded by andesite or dactte bod1es. The richest placers are near a contact zone with many quartz veins in carbonaceous slate of the schist un1t. Head of valiey is in Tertiary coel-beering rocks. Gold probably derived Erom Tertlary gravels (Cappg) or perhaps from wlmeralized schlot (Maddren). Gold 1n base of gravel and in top foot of schiat bedrock. Most of mining probably was in part of creek in Healy quad. Production, 1905-16 was worth about $\$ 80,000$. See also (Homestake $C r$. ) Healy quad.

Prindle, 1907 (B 314). p. 208-209 - Upper part of valley open and flat and underlain by coal-bearlng formation; lower part canyon in andesite. Mining at upper end of canyon and half a mile upstream. Gold coatse.

Brooks, 1911 (P 70), p. I72-173 -- Same a8 B 314.

Capps, 1911 (B 480), p. 221-224 -- Prelintanary to B 501.

Capps, 1912 (B 501), p. 44-46 -- Malng, 1910. Upper part of basla 15 underlain by sand, clay, gravel, and 11gnite; stream then flows through canyon in andes1te. Workable placers in and lumediately upstream of canyon. Gravels $6 \mathrm{ft}$. deep on decayed schist bedrock. Gold rusty and rather coarse. Gold probably derlved from high gravels. Production, 1906-09, about $\$ 50,000$.

Maddren, 1918 (B 662), p. 388 -c One of princlpal gold-producing creeks In Totatlanika bastn.

p. 395-397 -- Stream cuts through a ridge of schist intruded by andesitic or dactelc bodles. Richest placers below contact zone that contalns many quartz velns in carbonaceous slate (part of schyst unit); probable source of gold. Gold discovered near mouth of Fox Gulch [Healy quad.] In 1905; minling there and both upstream and downstream. Gravels 3-6 ft. thlck; most of gold in lower paxt and 1a top foot of schist bedrock. Some ground ran $\$ 5-\$ 7$ per cu. yd. Production, 1905-16, about $\$ 80,000$ in gold. All mining small scale because of shortage of water.

Smlth, 1937 (B 880-A), P. 46-- Small-8cale mining, 1935.

Smlth, 1938 (B 897-A), P. 56 -- Minlag, 1936.

Swith, 1941 (B 926-A), P. 51 - Mining, 1939. 
(Iowa $\mathrm{CI}_{.}$) Gold

Falrbanks district Fairbanks

$\mathrm{NE} 1 / 4 \mathrm{NE} 1 / 4 \mathrm{NE} 1 / 4$ quad.

Sumary: One report of gold worth $\$ 19.00$ per oz. (old price).

Prindle and Katz, 1913 (B 525), P. I13 -- Value of gold, \$19.00 per oz.; only one report. No other data. 
Janikgela

Falrbanks digtrict
$\operatorname{Iin}(?)$

Fa1rbanks (18.1, 17.5)

$64^{\circ} 58^{\prime} \mathrm{N}, 147^{\circ} 35^{\prime} \mathrm{W}$

Summary: Pegratite (?) at contact between mlca schlst and graphite sch1st; explored by 2 shafts. Cassitertte reporced to have been found.

H111, 1933 (B 849-B), p. 154 -- Mixture of quartz, feldspar, and mica on dump suggests pegmatite rather than quartz vein. Two shafts (one flooded and one caved at time of Hill's vig1t in 1931). Lode strikes $E$ and apparently follows contact between ralca schist and black graphite schist. Cassiterite sald to have been found; none noted in material on dump.

Chapman and Foster, 1969 (P 625-D), P. D15 -- Reference to B 849-B. 
Jennie $C$.

Falrbanks district

$M F-410,10 c .4$
Antimony

Falrbanks (14.4,15.5)

$64^{\circ} 52^{\prime} \mathrm{N}, 148^{\circ} 05^{\prime} \mathrm{W}$

Sumary: Iron-stained quartz veln as much as 18-24 inches thick contalns shoots and kidneys of stibnite. Some stibnite (3 tons or 100 tons, depending on gource of data) mined during world War I from trenches, shafts, and a tunnel. Includes references to McQueen.

Brooks, 2916 (B 649), P. 40-41 -- Ore body appears to struke N $50^{\circ}-$ $70^{\circ} \mathrm{W}$ and dip to north. Iron-stained quartz with stibnite in shoots and kidneys. Only a this fllm of oxidation products. In 1915 only a small pit had been dug to expose the deposit.

Chap1n, 1919 (B 692), p. 323 - Lode of nearly solld stibnlte; a little quartz; occurs in lenses; varles in wldth from a thin seam of gouge to 18-24 1ncher; strikes $N 45^{\circ} \mathrm{W}$, dips $75^{\circ} \mathrm{NE}$. Mined by surface trenching, hand picking, and sacking at mine, 1917. [No statement that ore was $801 d$.]

H111, 1933 (B 849-B), p. 157 - All workings caved by 1931. Veln probably strikes N $30^{\circ} \mathrm{E}$ and dips steeply eastward [very different attitudes from those reported by smith (B 649, $P, 40-41$ ) and Chapin (B 692, p. 323)]. More than 100 tons of stibaite said to have been shipped, 1916-18, from trenches, 2 shafts, and a tunnel.

Ebbley and Wright, 1948 (RI 4173), p. 38 -- Antimony ore has been produced.

Kllleen and Mertle, 1951 (OF 42), p. 12 -- Sample from dump contalned 28.121 So.

p. 14 - S1gnificant quantity of stibnite may have been mlned.

p. 19-20 - Small amount of stibnite mined during World War I; statements of amount differ ( 3 tons or 100 tons). Surface trenching, 2 shafts, and a tunnel exposed vein 18-24 in. Whde that carries stibnite. Sample from dump contained $28.12 \% \mathrm{Sb}$.

Chapman and Foster, 1969 (P 625 D), P. D19 se Stibnite shoots and kidneys in 1ron-stalned quartz. 
K1llarney

Falrbanks district

MF $-410,100.14$
Gold

Fa1rbanks $(14.85,15.55)$

$64^{\circ} 52^{\prime} \mathrm{N}, 148^{\circ} 00^{\prime} \mathrm{W}$

Sumary: Ras been some production from gold-bearing quartz velns in micaceous Bchist.

Chapman and Foster, 1969 (P 625-D), P. D18 -- Fractured and recemeated gold-bearlng quartz velns in mlcaceous schlst strike $\mathrm{N} 5^{\circ} \mathrm{E}$ and dip $75^{\circ} \mathrm{W}$. Has been gold production. 
Koegley

Falrbanka district

$M P-410,100.7$
Gold

Fairbanks $(14.4,15.15)$

$64^{\circ} 51^{\prime} \mathrm{N}, 248^{\circ} 04^{\prime} \mathrm{W}$

Summary: Short tunnel in mineralized schist cut by small quartz strtngers.. Whole mass bald to warrant milling; higheat gold content in quartz stringers.

Sw1th, 1913 (B 525), p. 206 w Short tunnel driven in mineralized sch1st cut by small quartz stringers. All material traversed by tunnel sald to carry enough gold to warrant milling; small quartz stringers richest.

Smlth, 1913 (B 542), p. 192 - Same as B 525.

Chapman and Foster, 1969 (P 625-D), P. D19 - Reference to B 525. 
Last Chance

Falrbanks d1strict

MF-410, 1oc. 17
Antimony, Gold

Falrbanks (14.95, 15.55)

$64^{\circ} 52^{\prime} \mathrm{N}, 148^{\circ} 00^{\circ} \mathrm{W}$

Sumbary: Gold has been produced from a steeply dipping quartz vein that is $2 \mathrm{ft}$. thick and contalog arsenopyrite, stibnite, and visible gold.

Chapman and Foster, 1969 (P 625-D), p. D18 -- Quartz vein 2 ft, thick contalns visible gold, stibnite, and arsenopyrite. Strikes NE and dips steeply northward. Has been gold production. 
(Last Chance $\mathrm{Cr}_{r}$ )

Falrbanks district

MF-410, 10c. 61
Gold

Falxbanks $(20.65,17.8-17.9)$

$64^{\circ} 59^{\prime}-65^{\circ} 00^{\prime} \mathrm{N}, 147^{\circ} 13^{\prime} \mathrm{W}$

Sumary: Placer mintag, 1911-14. Includes reference to (F1rst Chance CI., trib. F18h (r.)

Elisworth, 1912 (B 520), P. 243 - Mining on one clatm, 1911.

Ellsworth and Davenport, 1913 (B 542), p. 208 -- Mining, 1912.

Chap1n, 1914 (B 592), P. $359--$ Min1ng, 1913.

Eak1n, 1915 (B 622), p. 233 -- Mining, 1914. 
Leidy

Falrbanks district
Gold (?)

Fa1rbanks (18.8, 17.65 ) $64^{\circ} 59^{\prime} \mathrm{N}, 147^{\circ} 28^{\prime} \mathrm{W}$

Summery: Quartz veln; probably barren. Placer gold may have rested on surface over vein.

H111, 1933 (B 849-B), P. 155 -- Veln of glassy quartz strikes $N 70^{\circ} \mathrm{W}$, d1ps $50^{\circ} \mathrm{N}$. Shaft sunk $40 \mathrm{ft}$. on vein. Bedrock schist with a thin covering of placer gravel. Surface wag ground slulced; any gold from surface of veln was probably placer rather than lode. 
Lepsoe

Falrbanks district

\section{Gold (?)}

Falrbanks $(14.2,16.05)$ $64^{\circ} 54^{\prime} \mathrm{N}, 148^{\circ} 06^{\prime} \mathrm{W}$

Summary: Two clalms on a quarta veln parallel to grante porphyry dike. No data on metal content, if any.

H1Il, 1933 (B 849-B), p. I52 - Two cla1ms on a whlte quartz veln about 20 Et. wide that otrlkes $N 40^{\circ} \mathrm{W}$ parallel to g grante porphyry dike. Very little work on these claims.

Chapman and Foster, 1969 (P 625-D), P. D18 -- Reference to B 849-B. 
Liberty Bell

Bonnifielo district

MF-410, $10 \mathrm{c} .40$
B1smuth, Copper, Gold

Falrbanks $(8.8,1.0)$

$64^{\circ} 03^{\prime} \mathrm{N}, 148^{\circ} 51^{\prime} \mathrm{W}$

Summary: Some beds of a sedimentary series now metamorphosed to schist were selectively replaced by sulfide minerals (mainly auriferous arsenopyrtte and minor amounts of chalcopyrite, lollingtte, pyrtte, and blsmuthinfte); some free gold also. Ore body nearly horfizontal; badly crushed and sheared so caving inhlbited mining; seems to be limited above by a flat fault. Sulfides in lenses and stringers from a fraction of an inch to 18 in. thick. 'Deposit discovered in 1915; by 1930 over 1,000 ft. of workings; proved and probable reserves est1mated at 37,000 tons of $\$ 22$ ore. Mining and willng, 1931-33; possibiy in 1934 ; total production not given. Includes references to: Eva Creek Mining Co., Bonntfield dist.; Eva (Mintng Co.). Bonntfield dist.; Eva Quartz Mining Co., Bonnlfield dist.; lode wine on Eva $C r$.

Overbeck, 1918 (B 662), P. 351 -- Discovery of float mineralized with arsenopyrite, bismuth, and bismuthinite led to active prospecting, 1915-16, and discovery of several mineralized zones.

p. 355-356 - Near large fault. Begt materlal found is float that consists of arsenopyrite and quartz with small amounts of biamuth and bismuthinite and a very little chalcopyrite and pyrite. P. 360 -- Tunnel $35 \mathrm{ft}$. long and shaft $15 \mathrm{ft}$. deep opened $1 \mathrm{n}$ loose rock. Gold panned Erom decomposed rock at tunnel mouth and from a shear zone in schist. Shear zone strikes $\mathrm{N} 15^{\circ} \mathrm{E}$, dips $75^{\circ}$ $S$, and contains pyrite, arsenopyrite, chlorite, and scorodite (?). Brooks, 1919 (B 666), p. 98 -- Bismuth has been found in a gold prospect. Brooks, 1921 (B 714), P. 41 -- Reference to B 662.

Brooks and Capps, 1924 (B 755), p. 40 -- Development work, 1922. Assay returns indlcate a large body of ore with a promising gold content. Capps, 1924 (B 755), P. 139 -- Prospect has promise.

Brooks, 1925 (B 773), P. 31 -- Development continued, 1923. [Prospect Identified as bismuth-bearing lode in Bonnifield district.]

Smith, 1926 (8 783), p. 26 -- Development work reported, 1924.

Moffit, 1933 (B B36), p. 340-345 -- Bedrock geveral kinds of schist apparently derived from sedimentary rocks, Includtng calcareous members; faulted, sheared, and decomposed; rimbering reeded because of caving. Where mineralized princlpal sulfide is argenopyrite, with pyrite, chalcopyrlte, blsmuthinite, and gold; quartz gangue. Sulfldes appear as lenses and stringers in follation of schist; from a fraction of an inch to 18 inches thick; do not cross bedding. Some beds seem to have been much more favorable for replacement by sulfides than others. Gold both in arsenopyrite and free; silver present In only small amounts. Depostt diacovered, 1915. Developments by August 1930 lncluded over 1,000 ft. of adts and several shafts and ralses. Estimate of reserves by E. N. Patty was 37,000 tons of proved and probable ore wth an average assay of $\$ 22$ per ton. A few dikes 
Liberty Bell - Continued

of graniclc rock and of a rock that is now malnly hornblende in area. Schists in ore body nearly horizontal; serlcitized, altered, and crushed in ore body. Wavy, flat fault appears to be above, but not actually in contact with, ore body. Schist between the beds replaced by sulfides is bleached and softened and contains some disseminated sulfides.

Smith, 1933 (B 844-A), p. 19 -- M111 Installed; results better than antlclpated, 1931.

p. 80-8I - Ore valuable mainly for gold; considerable blsmuthinite present. More than a carload of concentrates shipped each month.

Smith, 1934 (B 857-A), p. 19 - Mined by a method simllar to longwall retreating coal mining; too much caving with normal drift mining; 1932.

p. 76 - Bismuthinlte in ore.

Smith, 1934 (B 864-A), 9. 23 -- Mrne does not operate in winter; other data repeated from earlier reports; 1933.

p. 80 -- Bismuthinite in are.

Smith, 1936 (B 868-A), P. 24 -- Very 11ttle work in 1934; mining expensive because of caving.

Smith, 1937 (B 880-A), P, 28-29 - . Mine acquired by new tntereats and beIng rehab1litated, 1935.

Smlth, 1938 (B 897-A), p. 35-36 - Al1 work discont1nued, midsumer 1936; some of machinery sold and removed.

Wedow and others, 1952 (OF 51), p. 72 -Reference to B 836, p. 340-345. p. 81 -- Mineral assemblage suggestive of presence of uranium.

White and others, 1952 (C 196), p. 9 -- Quartz stringers in schtst; arsenopyrite with minor amounts of pyrite, chalcopyrdte, bismuthinite, and free gold in quartz gangue.

Berg and Cobb, 1967 (B 1246), p. 202 -- Ore body is a nearly horizontal lode 6-30 ft. thick made up of sulfides; dissemlnated or in small lenses or stringers paraliel to follation in schist. Gold mainly In arsenopyrite, but some is frae. Other metallic minerals include small amounts of chalcopyrite, pyrite, lollinglte, and bistathinite.. Very little quartz. Reserve data from B 836, p. 343.

Hasler and others, 1973 (P 820), p. 98 - Bismuth minerals reported. 
Lincoln

Fairbanks distrlct
Gold (1)

Falrbanks $(14.85,15.65)$ $64^{\circ} 53^{\prime} \mathrm{N}, 148^{\circ} 00^{\prime} \mathrm{W}$

Summary: Assay of $\$ 160.00$ per ton (1n gold?) reported for grab samples.

Chapman and Foster, 1969 (P 625-D), P. D18-- "Grab samples from ore dump assay $\$ 160.00 \mathrm{Au}(?)$ per ton." 


\section{L1ttle Flower}

Falrbanke district

MP-410, loc. 15
Gold

Falrbanks (14.8, 15.4)

$64^{\circ} 52^{\prime} \mathrm{N}, 148^{\circ} 01^{\prime} \mathrm{W}$

Sumary: Gold has been produced from a veln. May be the same occutrence as Flower; attitudes of velns as reported at the two occurtences differ.

Chapman and Foster, 1969 (P 625-D), P. DI7 - Gold has been produced from a vein that trends north and dips $70^{\circ} \mathrm{E}$. 
(Little Moose $\mathrm{Cr}_{.}$)

Bornifield distriet

MF $-410,10 \mathrm{c} .63$
Gold, Tungsten

Fatrbanks $(8.15,0.6)$

. $64^{\circ} 02^{\prime} \mathrm{N}, 148^{\circ} 56^{\prime}-148^{\circ} 57^{\prime} \mathrm{W}$

Sumbary: Basin underlain by schist; high gravels on divides and 1ntertributary ridges. Placer mining in 2-4 $\mathrm{ft}$. of gravel in mile of stream course above confluence with Moose $\mathrm{Cr}$. Source of gold probably minerallzed zones (such as one near divide between Little Moose and Eva Creeks) in schist. Concentrates contain scarce scheelite. Mining reported for 1916 and 1937; was undoubtedly carried on in other years.

Maddren, 1918 (B 662), p. 365-368 - Headwater tributary of Moose Cr. Basin underlain malnly by schlst; high gravel on divides and intertributary ridges. Placer deposits all in lower mile of courge (above confluence with Moose $\mathrm{Cr}$.). Mining, 1916. Grave1 2-4 ft. thick. Sulfide mineralization has been found near divide between Little Moose and Eva Creeks. Source of placer gold probably mineralized zones in $8 \mathrm{ch} 1 \mathrm{st}$ rether than high gravels.

Sinth, 1939 (B 910-A), P. S5-- Mining, 1937.

Joestlng, 1943 (TDM 2), p. 20 -- Scarce placer scheelite.

Thorne and others, 1948 (RI 4174), p. 27 -- Scarce placer scheelite. Cobb, 2973 (B 1374), p. 111 -- Scheelite In concentrates. 
(Iittle Nugget Cr.)

Falrbanks d1strict

$M F-410,10 \mathrm{c}, 47$
Gold

Fatrbanks (14.9-15.05, 16.2-16.3)

$65^{\circ} 00^{\prime} \mathrm{N}, 147^{\circ} 59^{\prime}-148^{\circ} 00^{\prime} \mathrm{W}$

Sumary: Has been placer mining.

Chapman and Foster, 1969 (P 625-D), PI. 1 -- Area shown as having been placer mined. No other data. 
Lookout

Fa1rbanks distr1et

$M F-410$, loc, 2
Gold

Fairbanks $(14.0,14.75)$

$64^{\circ} 50^{\prime} \mathrm{N}, 148^{\circ} 07^{\prime} \mathrm{W}$

Summary: Some gold has been mined. A vein 1s cut by an auriferous dike.

Chapman and Foster, 1969 (P 625-D), P. Dl9 -- Gold has been produced. A NE-trending vein is cut by a 6-ft.-wlde auriferous leucocratic dike. 
Macomb

Fairbanks detrict

\section{Gold (?)}

Fafrbanks $(25.15,15.65)$

$$
64^{\circ} 53^{\prime} \mathrm{N}, 147^{\circ} 58^{\prime} \mathrm{W}
$$

Sumary: Caved shafts sunk on a ve1n. "Ore" on dump is crushed schist, gouge, and-quartz. No data on metal content, if any.

H1Il, 1933 (B 849-B), p. 152 -- Several clatms on veln that strikes $\mathrm{NE}$ and dips $60^{\circ} \mathrm{SE}$. Two shafts $30 \mathrm{ft}$. and $50 \mathrm{Et}$. deep; caved in 1931. Ore on dump is crushed schist, gouge, and quartz.

Chapman and Foster, 1969 (P 625-D), P. D17 -- Reference to B 849-B. 
Maloney

Falrbanks district

MP-410, loc. 3
Antimony

Falrbanks (14.2, 15.25)

$64^{\circ} 51^{\prime} \mathrm{N}, 148^{\circ} 05^{\circ} \mathrm{W}$

Summary: Shaft; matertal on dump malaly quartzite schlst; matertal in ore bin gouge and quartz with arsenopyrite and stibnlte.

HxII, 1933 (B 849-B), p. 123 - 90-Et. shaft said to Intersect (at 50ft. depth) a ledge sald to be $12-14 \mathrm{ft}$. wide, to strike ENE, and dip SE. Dump is mainly quartzlte schlat; ore plle largely gouge with oome quartz carrying arsenopyrtte and stibnite.

Kileen and Mertie, 1951 (OF 42), P. 20 -- Reference to B 849-8.

Chapman and Foster, 1969 (P 625-D), P. DI9 -- Reference to B B49-B. 
(McAdad(s) Cr.)

Bonn1field district

$M F-410,10 c .68$
Gold

Fatrbanks (10.05, 0.75) approx. $64^{\circ} 02^{\prime} \mathrm{N}, 148^{\circ} 42^{\prime} \mathrm{W}$ approx.

Summary: A little placer mining in 1930.

Moff1t, 1933 (B 836); p. 345 -- Dead work and a little mining, 1930.

Sm1th, 1933 (B 836), p. 41 -- Small-scale mining, 1930. 
McDonald (\& Morton)

Falrbanks district

MF-410, loc. 19
Antimony, Gold

Fa1rbanks $(15.0,15.2)$

$64^{\circ} 51^{\prime} \mathrm{N}, 148^{\circ} 00^{\prime} \mathrm{H}$

Summary; Several auriferous quartz velns with arsenopyrite and oxidation products; some also contain stibnite. Inclined shafts and other workings on 4 claims. Mining in 1931, 1937, and probably some other years. In 1931240 tons of $\$ 19$ ore from Blue B1rd workings; no data on other production. Includes references to: Blue B1rd Mining Co., Combination; see also WanderIng Jew.

Chapin, 1919 (B 692), p. 323 -- In 1917 a Eew shallow pits exposed a quartz veln with arsenopyrite scattered through it and coatings of scorodite and cervantite.

Moffit, 1927 (8 792), P. I2 - Shaft $30 \mathrm{ft}$. deep exposes horse of mineralized schlst with quartz velas on both walls; vistble gold.

HII, 1933 (B 849-B), P. 133-135 - Several groups of workings on 4 claims. The Blue Bird inclined shatt is $80 \mathrm{ft}$. deep on a vein that Btrikes $\mathrm{N} 35^{\circ} \mathrm{W}$, dips $65^{\circ} \mathrm{NE} ; 3$ levels of drifts. Veln terwinated by fault on 3 levels. 240 tons of $\$ 19$ ore mined from stopes and milled, 1931. At Combination shaft a 100-ft. Incline followed a veln striklng $\mathrm{N} 20^{\circ} \mathrm{W}$, dipping $45^{\circ} \mathrm{E}$, and with an average width of $3 \mathrm{ft}$. Vetn carries sulfide ore averaging $\$ 25$ to $\$ 40$ per ton; large boulders of stibnite-arsenopyrite ore on dump. On McDonald claim 4 subparallel nearly vertical velns strike $\mathrm{N} 40^{\circ}$ E; quartzarsenopyrite-stibntte ore.

p. 139 - - Blue Bird should not be confused whth clatm of same name belongling to Miller \& O!Connor farther $N W$ on same ridge.

Smtth, 1939 (B 910-A), P, 25 - Mining, 1937; ore taken to a custom mill. Joesting, 1942 (TDM 1), p. 11 -m Stibnite present; near a limestoneaplite contact.

Killeen and Mertie, 1951 (OF 42), p. 16-17 -- References to $B 692$ and B $849-B$.

Chapman and Poster, 1969 (P 625-D), P. Dl7 - Data mainly Exom above references. 
McGrath

Falrbanks district

NF-410, 10c, 25
Gold

Fatrbanks $(17.8,16.3)$

$64^{\circ} 55^{\prime} \mathrm{N}, 147^{\circ} 36^{\prime} \mathrm{W}$

Sumary: Low-grade gold-quartz vein in schist.

Chapman and Foster, 1969 (P 625-D), P. D16 -- Low-grade gold-quartz vein.

Mulligan, 1974 (IC 8626), p. 14 -- Gold-quartz veln in schist; no record of production. In residential area. 
(Melba Cr.)

Fa1rbanks district
Gold

Pairbanks (19.65, 17.9) $65^{\circ} 00^{\prime} \mathrm{N}, 147^{\circ} 21^{\prime} \mathrm{W}$

Summary: Has been placer mining. See also Vogt.

Chapman and Footer, 1969 (P 625-D), pl. 1 -- Area shown es hoving been placer mined. 
Mer1an

Fafrbanks district
Gold (?)

Falrbanks $(15.0,15.4)$ $64^{\circ} 52^{\prime} \mathrm{N}, 247^{\circ} 59^{\prime} \mathrm{W}$

Sumary: Tunnel drivan in schigt. No data on metal content, if any. H1Il, 1933 (B 849-B), p. 152 -- Long tunnel (caved 75 ft. from portal) In schist. 
Michley

Falrbanke district

MF-410, loc. 13

\section{Gold}

Fafrbanks $(14.75,15.75)$

$64^{\circ} 53^{\prime} \mathrm{N}, 148^{\circ} 02^{\prime} \mathrm{W}$

Sumary: Quartz veln 2-12 in. wide in schist. Ore milled about $\$ 10$ per ton. Developed by short drifts from a long tunnel.

H111, 1933 (B 849-B), p. 149 -- Crosscut has been driven through flatlying quartz-mica achist. Short drifts follow a quartz vein that strikes $\mathrm{N} 4^{\circ} \mathrm{W}$, dips $60^{\circ} \mathrm{E}$, and is $2-12 \mathrm{In}$. wide. Ore from a small stope milled about $\$ 10$ per ton. A higher tunnel follows this veln for about $50 \mathrm{ft}$.

Chapman and Foster, 1969 (P 625-D), P. D19-- Reference to B 849-B. 
Mohawk (Mining Co.)

Falrbanks district Mar $-410,10 c .17$
Antimony, Gold, Lead, Zinc

Falrbanks $(14.95,15.55)$

$64^{\circ} 52^{\prime} \mathrm{N}, 147^{\circ} 59^{\prime} \mathrm{W}$

Sumary: Major work on Mohawk and Bondholder clalds; some development on Yellow Jacket. Quartz veins with sch1st laclusions; some gouge. Ore contains free gold, arsenopyite, stibnite, galena, and ephalerite. Mohawk cla1m workings most extensive; vein developed for length of 1,300 ft. and to vertical depth of 232 ft. by 1931; average thickness of vein was $3 \mathrm{ft}$; are averaged more than $\$ 20$ per ton. Bondholder ore less rich and development simaller as of 1931. Total production through: 1931 was nearly 10,000 fine 02,; mine operated intermittently to 1940; no data on production. A few cons of stibnite was mined; about 5 tons probably was sold. Includes references to: Bondholder, Henderson ( $\&$ MCGIn). St. Patrick Creek, Tyndall \& Flnn, Tyndall \& Flynn, Yellow Jacket.

Smith, I913 (B 525), p. 209 -- Has been prospecting

Smith, 1913 (B 542), p. 195 -- Same as B 525.

Chapin, 1914 (B 592), P. 355 - Lode that strikes $N 20^{\circ}$ E and dips $40^{\circ}$

NW has been traced on surface for $500 \mathrm{ft}$. and opened by incline for

$20 \mathrm{ft}$. Ledge is $6 \mathrm{ft}$. Wde and is composed of quartz with inclusions of fragments and lenses of schigt. Gouge warks hanging wall; rlchest ore (free gold) in greentsh quartz stringer along hanging wal1. No sulfides noted. Footwall is made up of parallel joint planes marked by seans of gouge.

Eakin, 1915 (B 622), p. 237-238-- Mining, 1914. Considerable developmeat on Bondholder and Yellow Jacket claims as well as on Mohawk clata; 8 or 10 shefts and cunnels.

Brooks, 1916 (B 642), p. 61 - Development continued in 1915. Ad1t on Bondholder clatm now nearly $600 \mathrm{fr}$. long; cuts narrow minerallzed shear zones, but has not reached main lode.

Smith, 1917 (BMB 142), p. 24 -- Conslderable development work on Bondholder, Yellow Jacket, and Mohawk clatms; several shafts and a long access ad1t.

Mext1e, 1918 (B 662), p. 413-414 - Sumaty of data in B 592, p. 355. Long adit being driven to crosscut lode on Bondholder claim had not reached it by August, 1916. On Mohawk clalto 2 shafts expose 8-ft. vein of quartz containing stibntte and a little sphalertte; may be continuation of lode on Leah fraction [BIlly Sunday].

Martin, 1920 (B 712), p. 40 -- Mine operated and some ore willed, 1918. Brooks and Hartin, 1921 (B 714), p. 81 -- Minor wining, 1919.

Brooks and Capps, 1924 (B 755), p. 35 -- Tunnel driven $150 \mathrm{ft}$.; some ore mined.

Brooks, 1925 (日 773), p. 15 - Mining, 1923.

Swith, 1926 (B 783), P. 8 - "Considerable quantity of excellent ore" mined, 1924. Stibalte, galena, sphalerlte in ore, but only the free gold is recovered. 
Mohawk (Mining Co.) - Continued

Moff1t, 1927 (B 792), p. 11-12 - Largest output of any lode mine in district, 1925. Granular quarzz veln 1-5 ft. thick contalns free gold, stbnite, arsenopyr1te, galena, and sphalerite. Narrow parts of vein are richest; quartz near stibnite pockets (not aurlferous) 15 hlgh. grade.

Smtth, 1929 (B 797), p. 13 -- Mining, 1926.

Smith, 1930 (B B10), p. IS -- Mining, 1927. Water shortage hampered operation of mills in [Ester Dome] area.

Sintth, 1930 (B 813), p. 17 -- Mining, 1928.

Smith, 1932 (B 824), p. 19 -- Mining, 1929; also custom mllidng.

H1ll, 1933 (B 849-B), p. 142-147 - B claims; production more than $\$ 200,000$, malnly siace 1925 [as of 1931]; mostly from Mohawk veln, a Little frow Bondholder vein. Mohawk vein, In general, strikes $N 30^{\circ} \mathrm{E}$ and dxps $40^{\circ}-70^{\circ}$ (average $60^{\circ}$ ) ESE. Main workings cowprise more than 2,900 ft. of drtfts, 1,800 ft. of raises and winzes; veln developed for total length of $1,300 \mathrm{ft}$. and to vertical depth of $232 \mathrm{ft}$. Vein varles from $9 \mathrm{kn}$. to $6 \mathrm{ft}$. (average $3 \mathrm{ft}$.) in width. Ore ylelded $\$ 25$ to $\$ 35$ (average more than $\$ 20$ ), per ton. Some of ore contalns bunches of stibntte. Several velns other than Hohawk encouncered underground. Bondholder veln strtkes $N$ $24^{\circ} \mathrm{E}$, dips $45^{\circ} \mathrm{NW}$, Ls 4-1/2-7 ft. wide; cuts mica-quartz schist; contalns gold, arsenopyrite, stlbalte. Mining 1930-31; several hundred tons of ore milled; about $\$ 10$ per ton 1 n gold, Other velns exposed on property.

Sm1th, 1933 (B 836), p. 18-19 -. Mining, 1930.

Smtch, 1933 (B 844-A), p. 18 -- Minlag, 1931.

Smith, 1934 (B 864-A), p. 20 - No mining, 1932.

Smith, 1937 (B 880-A), p. 21 -- Development, 1935.

Smith, 1938 (B 897-A), p. 22 -n Development, 1936.

Swith, 1939 (B 910-A), p. 25 -- Mining, 1937.

Smith, 1941 (B 926-A), P. 23 -- Mining, 1939.

Smith, 1942 (B 933-A), p. 23 -- Activity [possibly mining], 1940.

Joesting, 1943 (TDM 2), P. Il -- Wide ve1n or lens of stibntte encountered in a ralse. At least 20 tons taken out of raise; 5 tons stacked on dump and the rest left underground. The 5 tons was taken to Falrbanks in 1942. [No information on any sale.]

K1lleen and Mertle, 1951 (OF 42), p. 12 - Sample of stiontte ore contafned $54.02 \% \mathrm{sb}$.

P. 14 - Minor amount of stibnite ore has been produced.

P. 18 -- References to B 662 and B 849-B. Also statement

that mine was active as late as 1940, but 1dle in 1942. Sample of sacked ore on property in 1942 contalned $54.02 \% \mathrm{Sb}$.

p. 26 - Ore on property would have to be resacked if sold.

Chapman and Foster, 1969 (P 625 D), P. D17 - Data mainly Erom above references and a UnIv. of Alaska B.S. thes1s. Some of faults in workIng way be thrusts. 
(Monte Cristo Pup)

Falrbanks district

MF- 410 , Loc. 58

\section{Gold}

Falxbanks $(19,65,13.9)$ $65^{\circ} 00^{\prime} \mathrm{N}, 147^{\circ} 2 I^{\prime} \mathrm{W}$

Summery: Placer mining in 1914.

Eak1n, 1915 (B 622), P. 233 -- M1aIng, 1914. 
(Mooge Cr., trib. Ester Cr.)

Antimony, Gold

Falibanks district

Fairbeaks $(14.4,15.25)$ approx. $64^{\circ} 51^{\prime} \mathrm{N}, 148^{\circ} 04^{\prime} \mathrm{W}$

Summary: Stibnite makes up cobbles as much as 6 in. In diameter in old placer worklngs. No further data on placer activity on this creek to this or any other reference to minting in the Falrbanks district, but it 1 s safe to assume that the placer miners were looking for and found some gold.

K1lleen and Mertịe, 1951 (OF 42), p. 12 -- St1bnite cobble contalned $62.11 \% \mathrm{Sb}$.

p. 20 - Cobbles of stibnite as much as 6 in. In diameter in old placer workings.

p. 42 -- Alluvial stibnite in gravels. 
Moose Cr., trib. Nenana R.)

Bonnifield district

MF-410, Locs. 39, 62
Gold, Mercury, Platinum, TIn, Tungsten

Eafrbanks (7.65-7.9,0.7-0.85)

$64^{\circ} 02^{\prime}-64^{\circ} 03^{\prime} \mathrm{N}, 148^{\circ} 58^{\prime}-149^{\circ} 00^{\prime} \mathrm{W}$

Summary: Dra1ns area of schlot wth remnants of Tertiary gravel on ridges. Oxidized echigt near head contalns arsenopyrite, pyrlte, and (determined by ascay) gold. Both creek and bench placero have been mined. Concentrates contaln gold, scheelite, cassiterite, cinnabar, and platinum-group metals. MinIng reported for most years from 1909 to as recently as 1940. Includes references to (B1g Moose $\mathrm{Cr}_{\text {. }}$ ); bee also (Moose $\mathrm{Cr}$.) Healy quad.; some of the clted references might be to mining on that creek.

Capps, 1911 (B 480), p. 221-222 -- Preliminary to B 501. Brooks, 1912 (B 520), p. 38 - Probably was mining in 1911.

Capps, 1912 (B 501), p. 44 - First production 1n 1909. Heads on schist ridge with remants of gravel capping. $100 \mathrm{oz}$. gold recovered from a Bravel bench with schist bedrock. Mining in 1910.

Maddren, 1916 (B 662), p. 364-368 - Basin eroded in schist overlatn by gravel; thick remnants on divides and intertributary ridges. Placers above and below mouth of Little Moose $\mathrm{Cr}$. Both creek and bench placerb. $100 \mathrm{oz}$. gold mined from bench in 1909. Mining of creek placers, 1916. Total output from basta (1ncluding Little Moose (r.), 1909-16, was worth about $\$ 30,000$. Stream placers in gravel 2-4 ft. thick; no contlnuous pay streaks. Some gold in high gravels, but Maddren conslders princlpal source of placer gold to be mineralized zones in schist.

Overbeck, 1918 (B 662), P. 351 - Lode clalms have been located.

p. 355 - Quartz porphyry 1ntrusives near head; placer gold In parts of stream courses that cut them.

p. 360 -- Spectmen of oxidized schiat from clatm at head of creek contalned arsenopyrite and pyrite; assay determined gold to be present.

Martin, 1920 (B 712), p. $44-$ Minlog, 1918.

Brooks, 1922 (B 722), P. 51 - Mining, 1920.

Brooks, 1923 (B 739), p. 35 -- Mining. 1921.

Capps, 1924 (B 755), p. 138-139-- Mining, 1922.

Smtth, 1930 (B 813), p. 35 -- Smal1-gcale minting, 1928.

Solth, 1932 (B 824), p. 40 -- Smal1-scale glntne. 1929.

Smith, 1933 (B B36), P. 41 - Smal1-gcale minlng, 1930.

Smith, 1933 (B B44-A), p. 41 - Smallmscale mining, 1931.

Solth, 1934 (B B57-A), P. 38 -- M1ning, 1932.

Sulth, 1934 (B 864-A), p. 42 - Mining, 1933.

Smith, 1936 (B 868-A), p. 44 - Mining, 1934.

Smtth, 1937 (B 880-A), p. 46 - Mining, 1935.

Smith, 1938 (B 897-A), P. 56 - Mining, 1936.

Smlth, 1939 (B 910-A), p. 55 -- Dragline plant Installed, 1937; output for distrlct 1nereased markedly [\$12,000 to $\$ 44,000$; table on p. 45].

Smlth, 1939 (B 917-A), p. 54 - Mining, 1938. Also prospect driling on benches. 
(Moose Cr., trib. Nenana R.) - Cont1nued

Sm1th, 1941 (B 926-A), p. 50-51 - Min1ng, 1939, Trled out a new gadget called a "one-bucket dredge."

Joesting, 1942 (TDM 1), p. 20 - Platinum has been found in placers.

p. 27 - Comon placer clnmabar.

p. 34 -- Scarce placer casiterite.

P. 39 -- Comon placer acheelite.

Sm1th, 1942 (B 933-A), p. 48 -- Mining ("one-bucket dredge"), 1940;

major producer in district.

Malone, 1962 (IC 8131), p. 56 -- Placer clnnabar coumon.

Malone, 1965 (IC 8252), p. 55 -- Placer clnnabar.

Cobb, 1973 (B 1374), P. Ild -- Concentrates contain scheelite, casslter1te, cinnabar, and platinum-group metals.

Hasler and others, 1973 (P 820), p. 98 - Bismuth minerals reported. ITh1s reference probably 15 to Liberty Bel1; data in clted reference are incorrect]. 
Mother

Falrbanks district

XPF-410, 200. 1
Gold

Fa1rbanks (14.0,15.8)

$64^{\circ} 53^{\prime} \mathrm{N}, 148^{\circ} 07^{\circ} \mathrm{H}$

Sumary: Brecclated 1ron-stalned quartz and sillcteled schlst carrles free gold.. Some of quartz averages $\$ 20$ a ton.

H111, 1933 (B 849-B), p. 120-122 -- Nearly vert1cal ledge strlkes east; about $20 \mathrm{ft}$. thlck; consists of 1ron-stalded quartz, siliclfied schlot, quartz breccla, and blue clay [gouge?]. Some of quartz averages $\$ 20$ a ton In gold; gome high-grade ore seen.

Chapman and Foster, 1969 (P 625-D), P. Di8 - Reference to B 849-B. 
(Nenana)

Falrbanks diatrict

\section{Limestone}

Fairbanke $(6.9,10.05)$

$64^{\circ} 34^{\prime} \mathrm{N}, 149^{\circ} 05^{\prime} \mathrm{W}$

Sumary: Lens of ilmestone in schist exposed in raflroad cut.

Waring, 1947 (C 18), p. 6, 8-- Lens of bluengray limestone in B1rch Creek schist exposed In rallroad cut; $400 \mathrm{ft}$. long; $1-4 \mathrm{ft}$. thick; grades laterally into siliceous schist. Analysis indicateo $2.1 \%$ insol., 1.1\% 1ron and aluminum oxtdes, $0.7 \% \mathrm{MgO}$. 
(Nugget Cr., tr1b. Goldatream Cr.) Gold

Falrbanks diatrict

Fa1rbanks (13.95-14.05, 16.0-16.05)

MF $-410,100.57$ $64^{\circ} 54^{\prime} \mathrm{N}, 148^{\circ} 07^{\prime} \mathrm{W}$

Sumbry: Placer gold mining, 1938-40.

Smith, 1939 (B 917-A), P. 43 -- Mintag, 1938.

Smfth, 1941 (B 926-A), P. 40 -n Min1ng, 1939.

SmIth, 1942 (B 933-A), P. 39 -- Mining, 1940. 
(Nugget Cr., rib. Smallivaod $C_{\text {. }}$ )

Fairbanks district

MF -410, lDc. 46
Gold

Fairbanks $(19.1-19.7,16.65-17.2)$

$64^{\circ} 57^{\prime} N, 147^{\circ} 23^{\circ}-147^{\circ} 26^{\prime} W$

Summary: has been placer mialag.

Chapman and Foster, 1969 (P 625-D), pl. 1 - Area shown as having been placer mined.

106 


\section{(O' Connor Cr.)}

Fairbanks diatrict

MF $-410,10 \mathrm{C} .50$
Gold

Patrbanko $(15.95,17.3)$

$64^{\circ} 58^{\prime} \mathrm{N}, 147^{\circ} 51^{\prime}-147^{\circ} 52^{\prime} \mathrm{W}$

Sumary: Stream flowg in an asymetrical valley similar to that of Blg Eldorado Cr. Ground 100-130 ft. deep. About $55 \mathrm{oz}$. of Bold worth $\$ 18.00$ per oz. mined in 1907.

Prindle, 1908 (B 337), p. 39, 41 -- Gold has been found; work had not progressed beyond prospecting stage tr 1907. Ground 100-130 ft. deep.

Prindle and Ratz, 1913 (B 525), p. 106 -. Valley agymetrfcal; very simliar to that of $\mathrm{B} 1 \mathrm{~g}$ Eldorado $\mathrm{Cr}$.

p. 111 - Gold worth $\$ 1,000$ mined in 1907.

p. 113 - Gold worth $\$ 18.00$ per oz. 
Parker

Fairbanks district MF -410, 10c. B
Gold

Fairbanks $(14.5,15,8)$
$64^{\circ} 53^{\circ} \mathrm{N}, 148^{\circ} 04^{\circ} \mathrm{W}$

Summary: Auriferous quartz vein 1-6 inches thick.

Chapman and Foster, 1969 (P 625 D), P. D19 - Irregular quartz vein 1-6 in. thick contain gold. Strikes $\mathrm{N} 15^{\circ} \mathrm{E}$, dips $55^{\circ} \mathrm{W}$.

108 
(Pearl Cr.)

Falrbanks d1strict

$M F-410,10 c .59$
B1smuth, Gold, Tungsten

Falrbanks (19.9, 17.7-17.8)

$64^{\circ} 59^{\prime} \mathrm{N}, 147^{\circ} 19^{\prime} \mathrm{W}$

Surmaxy: Placer gold ofned 1911-14, 1938-40. Concentrates contain nat1ve b16muth, wolframite, and much scheelite. Creek heads In axea with occurrences of lode scheelite. Includes references to (Yellow Pup $\mathrm{Cr}$. ); see also White Association.

Ellsworth, 1912 (B 520), p. 243 -- A pay streak sald to have been located, 1911.

Ellsworth and Davenport, 1913 (B 542), p. 208 -- Mining, 1912.

Chapin, 1914 (B 592), p. 359 -- Mining, 1913.

Eakin, 1915 (B 622), p. 233 -- M1n1ng, 1914.

Mert1e, 1918 (B 662), p. 421 -- Scheelite in concentrates.

Hill, 1933 (B 849-B), p. 71 -- Native bismuth in concentrates.

Solt th, 1939 (B 927-A), p. 43-44 - Mining, 1938.

Sirt th, 1941 (B 926-A), p. 40 -. Mining, 1939.

Joesting, 1942 (TDM 1), p. 39-40 -- Abundant placer scheelite and wolframte. Creek heads in area where scheolite occurs in contactmetamorphosed limestone and gold-bearing quartz velns near porphyritlc grante intrusive body.

Smith, 1942 (B 933-A), p. 39 -- Mining, 1940.

Joesting, 1943 (TOM 2), p. $27-$ Scheelite in float and reported (but not confirmed) in lode prospects. Scheellte and wolfxamlte in placers.

Wedow, White, and others, 1954 (C 335), P. I -- Reference to B 849-B, p. 71.

Byers, 1957 (B 1024-I), p. 188 -- Scheelite in concentrates. p. 210-211 - Scheelite from nearby lodes. 
(Pedro Cr.)

Falrbanks district

MF-410, 10c. 54
Gold, Tin

Falrbanks $(18.2-18.35,17.5-17.85)$

$64^{\circ} 59^{\prime}-65^{\circ} 00^{\prime} \mathrm{N}, 147^{\circ} 31^{\prime}-147^{\circ} 32^{\prime} \mathrm{W}$

Summary: Site of flrst gold discovery in distrlct. Headwater branch of Goldstream $\mathrm{Cr}$. Placers malnly deep and frozen. Mined, 1902 to as recently as 1940; dredge from 1930 on. Casstertte 1a a rare constituent of concentrates. Production usuadly re ported as part of Goldstream besin. See also (Pedro Cr.) Livengood quad.

Prindle, 1905 ( $B^{\prime} 251$ ), P. 67 - Gold discovered by Felix Pedro in 1902.

p. 75-77 - Depth to bedrock 8-30 ft., of which more than 20

ft. may be wuck overlylng 1-20 ft. of gravel. Base of gravel is clayey; it and top $1-5 \mathrm{ft}$. of bedrock contain all of the gold. Black sand, garnet, rutile, and pyrite also present. Mining in 1903-04 was by open cuts and drifting.

p. 83-84 - Bedrock is quartzite schist (Birch Creek) and locally porphyritic grante and gnelss. Gravels locally dertved. Purington, 1905 (B 263), p. 32, 42, 53-54 - Data on mining methods, costs, etc., in 1904 .

p. $208-$ Gold worth $\$ 18.40$ per oz.

Prindle, 1906 (B 284), p. Il1 - Has been mining (1905).

p. 118 -- D1stribution of values 1rregular.

Brooks, 1907 (B 314), P. 36 - Mining, 1906.

Prindle, 1908 (B 337), p. 29 -- Quotation Erom B 314.

p. 39 - Gold discovered, 1902. Has been a major producex.

Prindle and Katz, 1909 (B 379), p. 190, 193 -. M1ning, 1908.

p. 191 - - Depth to bedrock 9-35 ft.

Elisworth, 1910 (B 442), p. 232 -- Mining, 1909.

E11sworth and Parker, 1911 (B 480), p. 154-155 -n Mining, 1910.

Ellsworth, 1912 (B 520), p. 241 -- Mining, 1911.

E118worth and Davenport, 1913 (B 542), p. 206 -n Mining, 1912.

Prindle and Katz, 1913 (B 525), p. 105-106 -- Minlng, 1908. In some

places gold has been found through $8 \mathrm{ft}$. of gravel and $4 \mathrm{ft}$. of bedrock; In other places it is confined to bedrock.

p. 109 -- Depth to bedrock 8-40 ft.

p. I11 - Production, 1903-10, worth $\$ 1,250,000$.

P. 113 - Gold worth $\$ 17.68$ per oz.

Brooks, 1914 (B 592), P. 68 -- Minfng, 1913.

Chap1n, 1914 (B 592), p. 359 -- M1ning, 1913.

Eakin, 1915 (B 622), P. $234--$ Mining, 1914.

Brooks, 1916 (B 642), p. 59 -- Mining, 1915.

Sm1th, 1917 (BMB I42), p. 22-23 -- Mining, 1915.

Smith, 1917 (BMB 153), p. 51 -- Minlag, 1916.

Brooks, 1918 (B 662), p. 54 - Mining, 1916.

Sintth, 1929 (B 797), p. 20 -- Mining, 1926.

Smith, 1930 (B 810), p. 25 -- Mining, 1927.

Sutth, 1930 (B B13), P. 28 -- Mining, 1928.

Smlth, 1932 (B 824), p. 33 - Mining, 1929. 
(Pedro $\left.\mathrm{Cr}_{.}\right)$- Continued

Sm1th, 1933 (B 836), P. 32-33 - Dredg1ng, 1930.

Sm1th, 1933 (B 844-A), P. 32 -- Mining, lncluding dredglng, 1931.

Solth, 1934 (B 857-A), P. 30 -- Minlng, 1ncluding dredging. 1932.

Smlth, 1934 (B 864-A), p. 34-35 -- Mining, Including dredging, 1933.

Sm1th, 1936 (B 868-A), p. 35-36 -- Mining, Including dredging, 1934.

Smlth, 1937 (B $B 80-A$ ), p. $39--$ Mining, Including dredging, 1935.

Smlth, 1938 (B 897-A), p. 46 -- M1ning, lncluding dredging, 1936.

Salth, 1939 (B 910-A), P. 46 -- Mining, 1937 [no mention of dredge].

Smith, 1939 (B 917-A), P. 43-44, 74 -- Dredge operated, 1938.

Smlth, 1941 (B 926-A), p. 40,70-- Dredge operated, 1939.

Joesting, 1942 (TDM 1), P. 32 -- Rare placer cassiter1te.

Smlth, I942 (B 933-A), p. 38, 67 -- Dredge operated, 1940.

Wedow, Killeen, and others, 1954 (c 331 ), p. 6 -- Windrows of dredge tallings consplcuous in valley bottom.

Koschmann and Bergendahl, 1968 ( $P$ 610), p. 26 -- Workable placers discovered, 1902 ; first in area.

Cobb, 1973 (B 1374), p. 128 -- First gold diecovery in district, 1902. 
Peterson

Falrbanks district
Gold (?)

Patrbanks (17.9, 16.75) $64^{\circ} 56^{\prime} \mathrm{N}, 147^{\circ} 36^{\mathrm{i}} \mathrm{W}$

Sumary: Prospect holes in barren schlst and in overburden.

H111, 1933 (B 849-B), p. I53-- Proopect holes, most of which are in overburden or barren schtot; come "promlsing float" In surficlal macerial.

Chapman and Foster, 1969 (P 625-D), P. D16 - Refarence to B 849-B. 
Prometheus

Fa1rbanks d16trict

MF-410, 10c. 14
Ant1mony, Copper, Gold, S1lver

Faixbanke (14.85, 15.55$)$

$64^{\circ} 52^{\prime} \mathrm{N}, 148^{\circ} 00^{\prime} \mathrm{W}$

Summary: Quartz veln, possibly as much $a b 5 \mathrm{ft}$. Wlde, contalns 2 generations of quartz, gold, stibnlte, srsenopyrite, jameaonite, terrahedrite, covelilte, and chalcopyrite. Silver content very high ( $6.4 \mathrm{oz}$. per ton in assay of a grab sample). At least 60 tons of ore (on dump in 1931) mined from shaft $60 \mathrm{ft}$. deep; no record that any ore was milled or sold.

Smith, 1913 (B 525), P. 208 -- Hess and others have sunk a 60-ft. shaft on a quartz vela carrying stibnite and disseminated sulfides. Visible gold reported to be fatrly common.

Smith, 1913 (B 542), P. 194 - Seme as B 525.

Chapin, 1914 (B 592), p. 355 -- Samples from dump contained quartz (2 generations) cut by flue veinlets of stibnite. Some rocks have greenish-yellow antimony oxide staln.

Brooks, 1916 (B 649), p. 39 - Quotation from B 592, p. 355.

HI11, 1933 (B 849-B), p. 7I - Argentite may be present; if so 1 could account for high sliver content of ore.

p. 148 - Veln apparently otrdkes $N 40^{\circ} \mathrm{E}$; reported to be 5 ft. wide. 60 tons of ore on dump; whyte quarcz cut by gray quartz wh sulfldes; grab sample assayed $\$ 9.52$ in gold and silver $(6.40$ oz. Ag per ton); a specimen contalned arsenopyrite, famesonite, and covellite.

K1lleen and Mertie, 1951 (OF 42), P. I6 -- References to B 525, B 592, and $B \quad 849-B$.

Chapman and Footer, 1969 (P 625-D), P. D18 - References Include B 525, $B$ 592, and B B49-B. Minerale listed in these references, plus chalcopyrtte and tetrahedrite. 
Ptarmigan

Fairbanks district

$M-410,10 c .32$
Tungsten

Fafrbanks (19.6, 17.6) approx. $64^{\circ} 59^{\prime} \mathrm{N}, 147^{\circ} 23^{\prime} \mathrm{W}$ epprox.

Summary: Scheelite in quartz and sillcates that replaced 11my horfzons In schiat. See also Franklin.

Chaptn, 1919 (B 692), p. $327 \mathrm{~m}$ Scheelite in quartz and a111cates that presumably selectively replaced limestone. Lodes strike $\mathrm{N} 40^{\circ} \mathrm{E}$ and $\mathrm{d} \perp \mathrm{p} \mathrm{NW}$.

Chapman and Foster, 1969 (P 625-D), P. D16 -- Reference to B 692. Limestone here considered to be limy horlzons lo bchist. 
Rambier

Bonnifleld district

$M F-410,10 c .37$
Antumony, Gold, Lead, Stlver

Falxbankg $(8.1,1.15)$ approx. $64^{\circ} 04^{\circ} \mathrm{N}, 148^{\circ} 57^{\prime} \mathrm{W}$

Sumary: Small lenticular bodles of stibnite in black alaty schist. Several tunnels and a shaft. About 2 tons of ore mined (may not have been sold). Sample contained $47 \%$ antimony and traces of 8old, sllver, arsenlc, and lead. Includes reference to antimony lode on Cody Cr.

Maddren, 1918 (B 662), p. 368 -- Stibnite lode In basin of cody Cr. Overbeck, 1918 (B 662), p. 351 - Stfbnice lode; relocated in 1916.

p. 357 -- Stibnite in cryetol aggregate.

p. 360-36l - Two lenticllar bodies of stibnite in greatly oxidized serictee schist exposed by a cut; greatest thickness about $5 \mathrm{in}$; greatest length about $3 \mathrm{ft}$; larger lens curs across schistosity at slight angle. Annther stibnite body (apparently larger) was explored by a shaft (caved when visited in 1916).

Joesting, 1942 (TDM 1), p. 12 -- Stibnlte occurs ln small discontinuous bunches in black slaty schist; exposed in face of small cliff; cut off by fault a few feet back from cliff face. 3 tunnels, one $90 \mathrm{ft}$. long. driven into cliff. About 2 tons of high-grade stib nite mined and sacked during prospecting [no mention that any was shlpped]. Sample contalned $47 \% \mathrm{Sb}$ and traces of $\mathrm{Au}, \mathrm{Ag}$, As and $\mathrm{Pb}$. Berg and Cobb, 1967 (B 1246), p. 203 - 2 tons of ore containfng 47\% Sb mined from small discontinuous bunches of stibnite in black slaty schist. The ore also contained traces of $\mathrm{Au}, \mathrm{Ag}, \mathrm{As}$, and $\mathrm{Pb}$. 
Ready Buliion

Pairbanke diatrict MF-410, 10C. 10
Antimony, Gold

Falrbanks $(14.5,15.1)$

$64^{\circ} 5 I^{\prime} \mathrm{N}, 148^{\circ} 03^{\prime} \mathrm{W}$

Summary: Bedrock mlca schlst and quartzite. Ore is lenses and stringers of quartz and minexalized achlst in gouge $1 \mathrm{n}$ a crushed zone as much as $15 \mathrm{ft}$. wide and in other shear zones and thin quartz velns. Ore minerals are free gold, arsenopyrlte, stibntte, and one or more antimony sulfosalts. Mine developed from tunnels $600 \mathrm{ft}$. and $1,280 \mathrm{ft}$. long and shafts, one at least $180 \mathrm{ft}$. deep; several hundred feet of other worklags. Mining in 1912-13, 1926-31, 1933 was reported, but total production was not given; one stope ylelded about 3,600 tons of $\$ 6.09$ ore; much of the rest that was mined was richer. Includes references to: Borovich (\& Stevens), Hudson, Stevens \& Borovich.

Sm1th, 1913 (B 525), p. 203-206 -- Country rock is chlorite schist cut by many smsll quartz velns (up to an inch or so thick) and a fault marked by gouge and slickenslded surfaces and contalaing masses of barrep quartz. S1liclfled country rock suggests proximity of an 1ntrusive. Richest ore is quartz stringers (wh1ch carry visible gold), but nearby schist is also auriferous. Sulfide content of are 1s low. Mine developed by 2 shafts. Small mill expected to be operating by fall of 1912 .

Sm1th, 1913 (B 542), p. 189-192 - Same as B 525. Chapin, 1914 (B 592), p. 325 - Coating of manganese oxide on vugs in quartz veins.

p. 350-352 -- In 1913 shaft had been sunk $180 \mathrm{ft}$. Several levels; principal work on 100-ft. level. "B1g lead" appears to be a crushed zone $15 \mathrm{ft}$. wide dipping $45^{\circ}$ NW and filled with stringers and lenses of quartz and masses of minerallzed schist enveloped in gouge; followed for $160 \mathrm{ft}$.; cut of $f$ by fault that dips $60^{\circ}$ Sw. A 4-1n. quartz veln with many cavities and sparse stibnite was followed for $200 \mathrm{ft}$. Other veins also found in drifts. Best ore In stringers in "b1g lead" from surface to 70-ft. level. Brooks, 1916 (B 649), P. 40-41 -- Reference to B 592, p. 350-352. [Attitude given by Brooks does not agree with that given by Chapin In the cited reference.]

Smith, 1932 (B B24), P. 19 -- Mining and miling, 1929.

Hill, 1933 (B 849-B), p. 123-127 -- I8 cla1ms. Bedrock is mica sch1st and quartzite. Ore is in several veins and shear zones; "main veln" as much as $8 \mathrm{ft}$. thick; other velas are thinner and some shear zones wider. Veins contain several varieties [generations?] of quartz, gold, arsenopyrite, stibnita, and an antimony-lead sulfide (bournonite or boulangertte?). Some oxidation in all of workings (maximum depth $160 \mathrm{ft}$. ). Mine developed from 2 cunnels (600 ft. and 1,280 ft. long); several hundred feet more of crosscuts, drifts, ralses, etc. One stope ylelded about 3,600 tons of $\$ 6.09$ ore; much other ore was richer. [No data on rotal production.] Major development was in 1926 and following years; 


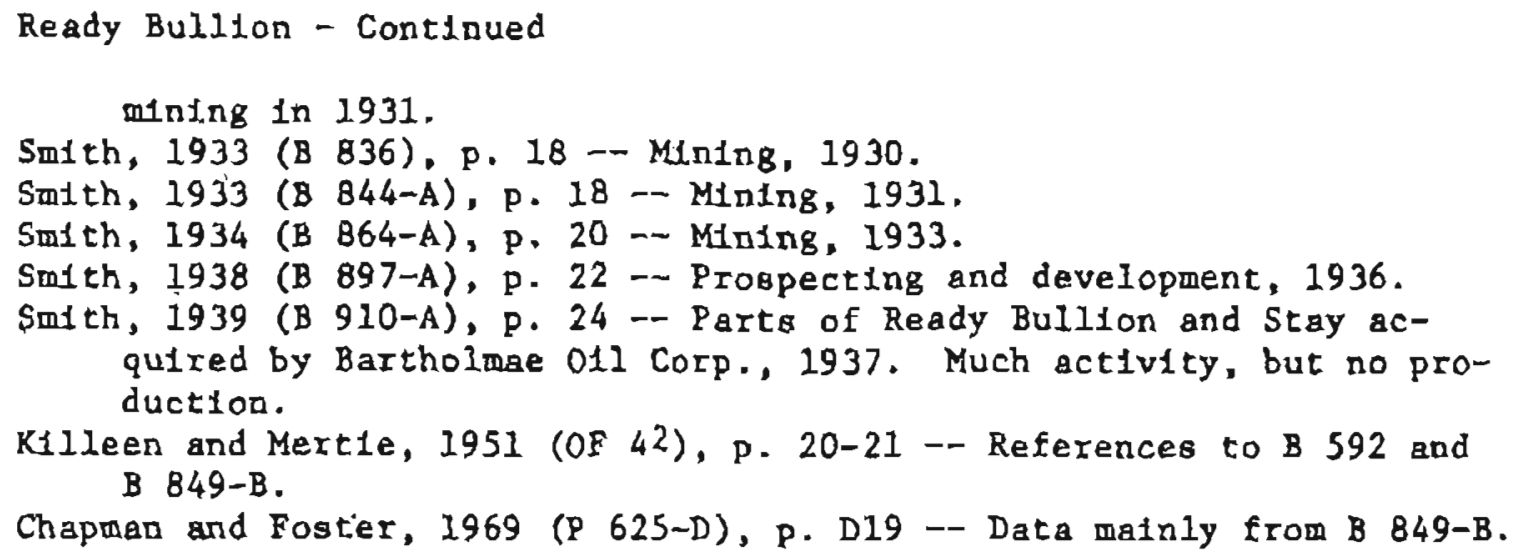


(Ready Bullion Cr.)

Falrbanks distr1ct

MP $-410,10 \mathrm{c} .44$
Gold

Falrbanks $(14.5-14.7,15.1-15.45)$

$64^{\circ} 51^{\prime}-64^{\circ} 52^{\prime} \mathrm{N}, 148^{\circ} 02^{\prime}-148^{\circ} 04^{\prime} \mathrm{W}$

Sumary: Placer gravels as much as $80 \mathrm{ft}$. below surface. Mined from 1907 to 1914. Production well over 25,000 fine oz. Several hundred tons of ore sald to have been mined from broken velns and masaes of quartz in Bchlat on ridge SW of creek.

Ellsworth, 1910 (8 442), p. 234 -- Mining, 1909.

Ellsworth and Parker, 1911 (B 480), p. 157-158 - Winter ofining and slulcing, 1910. Hot exhaust from pump englnes kept slulces and water unfrozen.

Ellsworth, 1912 (B 520), p. 243 - Mining, 1911.

Ellsworth and Davenport, 1913 (B 542), P. 209 -- Winter mining, 1911-12.

Prindle and Katz, 1913 (B 525), p. 110 -. Depth to bedrock $80 \mathrm{ft}$.

P. 112-113 -- Production, 1907-10, worth $\$ 500,000$. Gold worth $\$ 16.38$ per oz.

Chap 1n, 1914 (B 592), p. 359 -- Mining, 1913.

Eak1n, 1915 (B 622), P. 235 -- Mining, 1914.

Chapman and Poster, 1969 (P 625-D), P. D19 -. "Several hundred tons of high-grade ore were mined from broken sections of velns and quartz masses In schist." Shown on $\mathrm{Pl} .1$ as on ridge SW of creek. 
(Rex Cr.)

Bonnifield distrtct

$\mathrm{ME}-410,10 \mathrm{C}, 64$
Antimony, Copper, Gold

Falrbanks $(8.9,1.9)$

$64^{\circ} 06^{\prime} \mathrm{N}, 148^{\circ} 50^{\prime} \mathrm{W}$

Sumary: Stream heads in schist; lower part of courbe cut in Tertiary coal-bearlng rocks. Both gtreann and bench gravels contain irregularly diatributed gold. Most placer mining was between 1905 and 1910; total production was probably less than $250 \mathrm{oz}$. of gold. Quartz velas carry atfbrite, chalcopyrite, and pyr1te; no development reported.

Capps, 1911 (B 480), p. 221-222, 224 -- Preliminary to 8501. Capps, 1912 (8 501), P. 44 -- Mining, 1910.

p. 47 -- Prospecting since 1905. Stream heads in schiat hills with remants of gravel capping; lower part of course in coalbearing rocks. Both stream and bench gravels carry irregularly d1strlbuted gold. Ground worked was 6-8 ft. deep with gold close to or in top foot of decayed schist bedrock.

Maddren, 1918 (B 662), p. 380-383 -- Upper $5 \mathrm{ml}$. In schtst; lower $3 \mathrm{ml}$. 1n coal-bearing rocks; sch1st probably only recently stripped of coal-bearing rocks. Best gold prospects and only mining 3-4 ml. above mouth. Bench $50 \mathrm{ft}$. above stream was mined in 1910; reference to B 501, p. 47. Has been prospecting of creek gravels. Total production through 1916 worth about $\$ 5,000$. No mining in 1916 and probably nane since 1910.

Smlth, 1939 (B 917-A), p. 54 - Large tract acquired by Bartholomae 011 Corp. . 1938; dragline mining contemplated.

Smith, 1941 (B 926-A), p. 51 - Prospect dr1lling begun, 1939.

Joesting, 1942 (TDM 1), P. 12 -- Stibntte lode reported about $2 \mathrm{ml}$. NE of Cody Cr. [Rambler] prospect.

Berg and Cobb, 1967 (B 1246), p. 202-203 -r Quartz velus carry stibnite, pyrite, and chalcopyrite. 
R1dge

Fairbanks district

MF-410, loc. 26
Gold

Fairbanks $(18,1,16.45)$

$64^{\circ} 55^{\prime} \mathrm{N}, 147^{\circ} 34^{\mathrm{k}} \mathrm{W}$

Summary: Quartz veln; 2 shallow shafts; sample from dump contalned 8old worth.\$15.96 per ton.

H111, 1933 (B 849-B), P. 153 -. Two shafts sunk about $15 \mathrm{ft.}$ on a veln about 14 1n. wide that strikes $N 50^{\circ} \mathrm{E}$ and dips south. Grab sample of ore on dump assayed $\$ 15.96$ per ton.

Chapman and Foster, 1969 (P 625-D).. P. D16 - Reference to B 849-B. 
Rogach

Falrbanks distrlet
Bold (P)

Falrbanks (14.3, 15.75)

$64^{\circ} 53^{\circ} \mathrm{N}, 148^{\circ} 05^{\prime} \mathrm{W}$

Summary: Cold (?) prospect. No other data.

Chapman and Foster, 1969 (P 625-D), P. D18 $\ldots$ Ligted in table as a prospect; no other data. 
(Roosevelt $\mathrm{Cr}$. )

Bonnifleld distict

MF -410 , 10c. 76
Gold

Falrbanks (14.1, 1.3) approx. $64^{\circ} 04^{\prime} \mathrm{N}, 148^{\circ} 10^{\prime} \mathrm{W}$ approx.

Summary: Small, flat, well-worn pleces of gold in $2 \mathrm{ft}$. of stream gravel on Interbedded clay, sand, gravel, and coal of Tertlary coal-bearing formation, which 18 overlain by Nenana gravel, which 18 the probable source of the gold. No hard rocks in basin. Small-scale minling in 1910 and 1916 reported.

Prindle, 1907 (B 314), p. 210-211 -- Bedrock is clay and sand of coalbearing formation. Stream gravel, and probably the gold, derlved from overlylig thick gravel bed. Gold in amall, flat, well-worn pieces.

Brooks, 1911 (P 70), p. 173-174 -- Same as B 314.

Capps, 1911 (B 480), p. 221-222, 225-226 -- Preliminary to B 501.

Capps, 1912 (8 501), p. 44 -- Mining, 2910.

p. 48-49 - No hard rock in basin. Gold derived from high gravels on clayey of sandy layers of coal-bearing serfes. Smallscale mining in 1910.

Maddren, 1918 (B 662), p. 399-400 - R18es on r1dge of Nenana Gravel; lower part of stream course has cut down into coal-bearing formation. Placer gold in about 2 ft. of gravel on clay, sand, gravel, and lignite of coal-bearing formation; gold probably derived from Nenana Gravel. Minlng, 1916. 
(Robe Cr., lode)

Falrbanks district

MF-410, Ior. 28
Antimony

Faltbanks $(18.45,13.35)$

$64^{\circ} 58^{\prime} \mathrm{N}, 147^{\circ} 29^{\prime} \mathrm{W}$

Sumary: T1ny velnlets of stibnlte in a quartz-feldspar lode that is 6-8 1nches, wide, strikes $\mathrm{N} 30^{\circ} \mathrm{E}$, and dips 70 $\mathrm{NW}$, Apparently has been no exploration or development since 1913.

Smith, 1913 (B 525), P. 198 -- Lode locaced by Isaac Ogram.

Smlth, 1913 (B 542), p. 184 - Same as B 525.

Chapin, 1914 (B 592), P. 346 -- Quartz-feldopar 1ode 6-8 1n. wide sertkes $\mathrm{N} 30^{\circ} \mathrm{E}$, d1ps $70^{\circ} \mathrm{NW}$; opened by 15-ft. shaft and Incline; parallel velns opened by ptts. Only mineralization is tiny velnlets of stibnite.

Brooks, 1916 (B 649), P. 24 -- A 11ttle antimony ore has been found. p. 41 - Quotation from B 592, p. 346.

K1lleen and Mert1e, 1951 (OF 42), p. 6 -r Minor occurrence of otibntte. p. 39 -- References to B 592 and B 649, p. 24.

Chapman and Poster, 1969 (P 625-D), P. D16 -- Reference to B 592.

Mulligan, 1974 (IC 8626), p. 13 - Data same as in P 625-D. 
(Rose Cr., placer)

Falrbanks district

MF -410 , loc. 55
Gold, Tungsten

Fatrbanks $(18.35-18.4,17.4-17.45)$ $64^{\circ} 58^{\prime}-64^{\circ} 59^{\prime} \mathrm{N}, 147^{\circ} 31^{\prime}-147^{\circ} 32^{\prime} \mathrm{W}$

Summary: Has been placer gold mining. Scheielte in concentrates. Includes reference to (New Years Pup).

Prindle and Katz, 1913 (B 525), p. 113 - Gold worth \$18.00 per oz. Chapin, 1914 (B 592), P. 359 - Coarse gold mined on New Years Pup, 1913.

Byers, 1957 (B 1.024-I), p. 188 - Scheelite ln concentrates.

p. 210-211 -- Scheelite from nearby lodes. 
Royal Flush

Fairbanks district $M F-410,10 c .16$
Gold

FaIrbanks $(15.25,15.7)$

$64^{\circ} 54^{\prime} \mathrm{N}, 148^{\circ} 00^{\prime} \mathrm{W}$

Summary: Quartz vein $3 \mathrm{ft}$. wide; production was 208 tons of $\$ 47.50$ ore, probably in 1937.

South, 1939 (B 910-A), p. 25 -- Cold production reported, 1937.

Chapman and Foster, 1942 (P 625-D). P. D18 - Produced 208 tons of ore averaging $\$ 47.50$ in gold per ton from a $3-f t$. wide vela that strikes $N 42^{\circ} \mathrm{E}$ and dips $70^{\circ} \mathrm{W}$.

125 
Ryan

Falrbanks diatrict Mra 410 , loc. 18
Antimony, Gold

Fatrbanke $(15.0,15.4)$ $64^{\circ} 52^{\prime} \mathrm{N}, 147^{\circ} 59^{\prime} \mathrm{W}$

Summary: Mineralized fault zone contalns sheared schiat and quartz veins in a. lode 40-70 ft. wide. Metallic minerals are gold, arsenopyrite, and ottbnite. Large body of low-grade materlal and a few tens of thousands of tons of $\$ 10$ (old gold price) matertal. Extensive underground workings (nearly a mile) and trenchtng, but not much ore mined and milled.

Brooks; 1912 (8520), p. 33 -- Work on ledge 1n 1911; shlpment of ore to custom mill reported.

Smlth, I913 (B 525), p. 207 - Vein as much as 16 1n. wide; faulted near bottom of shaft (about $90 \mathrm{ft}$. deep). Considerable gouge near fault.

Smith, 1913 (B 542), P. 193 -r Same as B 525.

Mert1e, 1918 (B 662), p. 413-- Prospecting, 1916. On Monte and Eva clalms lode is shattered mixture of quartz and country rock 15-20 ft. thick and striking $N 25^{\circ} \mathrm{E}$. Much arsenopyrite. On Ryan clatm 35-foot-deep shaft reached mineralized zone in schlst; quartz, gold, arsenopyrtte, stibnlte.

Chap1n, 1919 (B 692), p. 323 - Development work Oct. 1916-June 1917. Lode strikes about north and dips steeply east; carrles considerable stibulte.

Moffit, 2927 (B 792), p. 12 -- Shaft and open cuts expose a veln a few inches thick with gangue along footwall.

Sm1th, 1930 (B 810), p. 15 -m Large body of low-grade quartz. Property reported sold to an English company, 1927.

Sm1th, 1930 (B 813), p. 17 - Properey reported opt1oned to an English company, 1928.

Smith, 1932 (B 824), p. 20 - No act1vity, 1929.

H11, 1933 (B 849-B), p. 135-138-7-1/4 patented cla1ms. Lode Is a fault zone in schlst; crushed schlst and quartz velns $40-70 \mathrm{ft}$. wide; strikes $\mathrm{N} 20^{\circ}-25^{\circ} \mathrm{E}$, d1ps $45^{\circ}-70^{\circ}$ (average $50^{\circ}$ ) $\mathrm{B}$. Most of metal content is falily persistent zone of quartz 9-20 ft. wide near hanging-wall bide of lode. Pault movernent was mainly postmineralization. Sampling indicates a considerable tonnage of low grade materlal and a few tens of thousands of tons of \$lO ore. No record of production as of 1931 [see B 520, p. 33]. Prospect explored by shallow shafts and pits, a tunnel $300 \mathrm{ft}$. long, and $a$ shaft $200 \mathrm{Ft}$. deep. Deposit contains some arsenopyrite and otibnite.

Smith, 1933 (B 836), p. 19 -- Rumorg that mine w11 be reopened, 1930. Sm1th, 1933 (B 844-A), P. 18-19-- Invest1gated and sampled by eng1reer, 1931. Lode 18 wide and of 10 grade.

SmIth, 1936 (B 868-A), p. 20 Option for expilorat1on, 1934. Smlth, 1939 (B 917-A), p. 26 -- Bartholomae 011 Co. got optlons in 1938. Cleaned out old shaft to depth of $160 \mathrm{ft}$, drove $330 \mathrm{ft}$. of drift and several hundred feet of crosscuts and ralses. Ore taken out during development was milled at another property. 
Ryan - Continued

Sm1th, 1941 (B 926-A), P. 23 -- Work suspended for most of 1939 season. Joesting, 1942 (TDM 1). P. 11 -- Lenses of Btibnite have been found. Sm1th. 1942 (B 933-A), P. 23 -- Large amount of development work (trenches and geophysical work), 1940; 11ttle if any production. K1lleen and Mertle, 1951 (OF 42), p. 17 -- References to B 692 and B 849-B.

Chapman and Foster, 1969 (P 625-D), P. D17 -- Most of data from above references.

Warfleld and Thomas, 1972 (USBM OF 23-72) -- Fault zone of crushed schist and quarez velne $40-70 \mathrm{ft}$. wide (strike $\mathrm{N} 20^{\circ}-25^{\circ} \mathrm{E}$, dip $45^{\circ}-70^{\circ}$ E) is hanging wall of mefor shear zone $750-1,500$ Et. wide. Major metalife minerals in vein system are gold, arsenopyrtte, and stibntte. In 1916-17 about $500 \mathrm{ft}$. of shaft and winze and $970 \mathrm{ft}$. of drifis and crosscuts; thorough sampling. Additional exploratIon and development, 1917-30, Included a 65-ft. shaft and a crosscut. 1938-42 saw more then $1,500 \mathrm{ft}$. of shafts, 2,000 of drifts, od1ts, and crosscuts, and more than 2,800 ft. of trenches. Ore removed during development put through custom mill. Minor trenchIng and drilling, 1954-58. USBM driling program in 1969-70 was a pllot study to compare rotary drilling and bulldozer tronching from cost and environmental damage points of view and was not intended to result in new knowledge about the deposit. 
(St. Patr1ck Cr.)

Fa1rbanks detrict

MPu 410 , Ioc. 49
Gold

Ralrbanke (15.2, 15.55) epprox. $64^{\circ} 56^{\prime} \mathrm{N}, 147^{\circ} 58^{\prime} \mathrm{W}$ approx.

Sumary: Placer minting or prospecting between 1909 and 1916. No good data on amount produced, but it was undoubtedly emall by Falrbanks district standards. Many lode mines and prospects in dratuage basio.

Ellsworth, 1910 (B 442), p. 234 -- Work [mlndng or prospecting], 1909. Elloworth and Parker, 1911 (B 480), p. 158 -- Very little actual mining in 1910. Ellswoxth, 1912 (B 520), p. 243 - Mining, 1911. Prindle and Katz, 1913 (B 525), P. 112-113 - Production, 1910, worth $\$ 17,000$, Gold worth $\$ 17.50$ per oz. ITh1s does not agree with $B$ 480$, p. 158.$]$

Eak1n, 1915 (B 622), P. 235 -- Mining, 1914.

Sw1th, 1917 (BMB 142), p. 23 -- Mining, 1915.

Smith, 1917 (BMB 153), p. 5I -- Mining, 1916. 
St. Paul

Falibanks distrlct MF-410, 10c. 15
Antimony, Cold

Patrbanks $(14.8,15.4)$

$64^{\circ} 52^{\prime} \mathrm{N}, 148^{\circ} 03^{\prime} \mathrm{W}$

Sumary: Barren quartz veln fractured and then gold was deposited. Stibnite and arsenopyrite in ore. Country rock schist. 1,000 tong of $\$ 30$ ore mined and milled.

Mercle, 1918 (B 662), p. 409-410 - Extensive prospecting, 1916; mill Installed and 370 tons of ore milled. Workings are shaft, incline, and tunnel (total length $257 \mathrm{ft.}$ ). Vein of massive vitrem ous quartz about $3 \mathrm{ft}$. thick strikes sbout $N 40^{\circ} \mathrm{E}$ and dips $38^{\circ}$ NW. Quartz and schlst country rock decayed, shattered, and Iron stalned. Stibnite and 1 ts alteration products slong footwall; gold content lower neal stibnte. Mertie thinks that deposition of gold was later than quartz veln, but was localized by shattered nature of vein along a post-vein fault.

Chap1n, 1919 (B 692), P. 323 -- Mine operated throughout 1917. M111 has capacicy of 20 tons pex day.

Mart1a, 1920 (B 712), p. 40 -- M1ning, 1918; $150 \mathrm{ft}$. of tunnel dr1yen; none of ore milled. M111 operated on ore from B1lly Sunday and Mohawk.

Brooks and Martin, 1921 (B 714), p. 81 -- A l1ttle mining, 1919.

H111, 1933 (B B49-B), P. 128-129 - Tunnel driven $250 \mathrm{ft}$. on a veln that trends $N 30^{\circ}$ E and dips $45^{\circ}-70^{\circ} \mathrm{W}$. 6-8 in. of quartz nert to hanglng wall; lode $3-4 \mathrm{ft}$. wide. 1,000 tons of $\$ 30$ ore mined and mllied. Dump had pleces of stlbnite-arsenopyrite-quartz ore.

Killeen and Mertie, 1951 (OF 42), p. 15-16-- References to $B 662$ and B 849-B.

Chapran and Foster, 1969 (P 625-D), P. D18 -- References to 662 and B 849-B. 
Sanford

Falrbanks district MF-410, 1oc. 12
Gold

Fa1 Kbeaks $(14.8,15.9)$

$64^{\circ} 54^{\circ} \mathrm{N}, 148^{\circ} 01^{i} \mathrm{~W}$

Sumary: Gold quartz veln opened by Inclined ahaft, drifts, and stope. 150 tons of ore milled ylelded $\$ 6,700$.

H1II, 1933 (B 849-B), p. 149 -- Inclined shaft sunk $105 \mathrm{ft}$. on vein that strikes $\mathrm{N} 40^{\circ} \mathrm{E}$ and dips $45^{\circ} \mathrm{SE}$; several drifts and stopes. About 150 tons of ore mined and milled ylelded $\$ 6,700$; some of ore averaged $\$ 52$ per ton. Another veln (said to have covered some high-grade ore) strikes $N 20^{\circ} \mathrm{E}$ and $1 \mathrm{~s}$ vertical.

Chapman and Foster, 1969 (P 625-D), P. D18 -r Reference to B 849-B and note that mine was also called Lone Tree. 
Schubert

Fafrbanke district

MP -410, loc. 31

\section{Tungsten}

Fatrbanks $(19.4,17.45)$

$64^{\circ} 59^{\prime} \mathrm{N}, 147^{\circ} 23^{\prime} \mathrm{W}$

Summary: Sparsely acattered gralns of scheelite in 2-in. band in ollicated ilmestone near contact between schlat and porphyritic grantite.

Byers, 1957 (B 1024-I), P. 189 -- Probably staked on a amall leas of scheel1te-bearing sillcated schist.

p. 201 -- 35-ft. trench exposed granite-schlst contact. Bedding is vertical and strikes $N 35^{\circ}-40^{\circ}$ E. Log of bottow of treach ts: $20 \mathrm{ft}$. porphyrit1c granite, $1 / 2 \mathrm{ft}$. glassy quartz, 7-1/2 ft. hornfelsic mica schist, $7 \mathrm{ft}$. scheelite-bearing silicated Ilmestone and limestone. Scheelite occurs as sparsely scattered grains in a 2-1n. band 1n sillcated limestone.

Berg and Cobb, 1967 (B 1246), P. 220 -- Sparse scheelite in metamorphosed IImestone at contact of porphyritic grantte.

Chapman and Foster, 1969 (P 625-D), P. D16 - Reference to B 1024-I, p. 201. 
Seattle Fraction

Fairbanks district
Gold (?)

FaIrbanks $(14.9,15.4)$

$64^{\circ} 52^{\prime} \mathrm{N}, 148^{\circ} 00^{\prime} \mathrm{W}$

Summary: Gold (i) prospect. No other data.

Chapman and Foster, 1969 (P 625-D), P. D17 -- Listed In table as a prospect; no other data.

192 
(Sheep Cr.)

Palrbanks distrjct MF-410, 1oc. 47
Gold

Falrbanks (14.85-15.0, 16.05-16.2) $64^{\circ} 59^{\prime} \mathrm{N}, 147^{\circ} 59^{\prime}-148^{\circ} 00^{\prime} \mathrm{W}$

Sumary: Has been placer minting.

Chapman and Foster, 1969 (P 625-D), P3. 1 - Area shown as having been placer mined. 
Palrbanke district

Fairbanks $(14.45,15.3)$

$\mathrm{MF}-410$, 10c. 5

$64^{\circ} 52^{\prime} \mathrm{N}, 148^{\circ} 03^{\prime} \mathrm{W}$

Summary: Quartz vein about $5 \mathrm{ft}$. whde crushed by postmineralization faulting. About $\$ 4,000$ in gold produced from a shaft and tunnel.

H111, 1933 (B 849-B), P. 127-128 - Veln strlkes $\mathrm{N} 30^{\circ} \mathrm{E}$, dips $68^{\circ} \mathrm{SE}$, is about $5 \mathrm{ft}$. wide; conglote malnly of crushed quartz with some altered schlat. Developed by shaft and tunnel. Production about $\$ 4,000$. A aecond tunnel has boen driven $515 \mathrm{ft}$. , but has not hit vein.

Chapmen and Foster, 1969 (P 625-D), p. D19 -- Data mainly from B 849-B. 
(Smallwood $C \tau_{\text {. }}$ )

Falrbanks district

NP-410, 10c. 60
Gold

Falrbanks (19.7, 16.6-16.75)

$64^{\circ} 55^{\circ} \mathrm{N}, 147^{\circ} 21^{\prime} \mathrm{W}$

Summary: Bedrock 18 schlst with grante at head of creek. Placer ground is deep ( $40 \mathrm{ft}$. near head of creek increasing downstream to more than $300 \mathrm{ft}$. ); gold in 3-4 ft. of gravel and upper part of bedrock. Mining reported from 1907 to 1916 and in 1927. No data on total production or composition of concentrates.

Brooks, 1908 (B 345), p. 41-42 -- Has been prospecting and some production for several years (1907). New discovery $5 \mathrm{ml}$, below older mining area at depth of $320 \mathrm{ft}$.; no ldea if 1 t might be commercial.

Prindle, 1908 (B 337), p. 46-47 -- Bedrock of most of basin probably 1s mica schist; oome granite. Depth to bedrock increases from about $40 \mathrm{ft}$. near head of creek to $200 \mathrm{ft}$. $5 \mathrm{ml}$. below, to $317 \mathrm{ft}$. at claim 17 below.

Prindle and Katz, 1909 (B 379), p. 191 -- Depth to bedrock 100-140 ft.; muck $17-40 \mathrm{ft}$. thick.

Ellaworth, 1912 (B 520), p. 244 -- Mining, 1911.

Ellsworth and Davenport, 1913 (B 542), p. 208 -. Minting, 1912.

Prindle and Katz, 1913 (B 525), p. 103 -- Heads in granite IGIlmore

Dome]. Ground 1s deep. Productive gravels reported to be $120 \mathrm{ft}$. wide, 3-4 ft. thick. Gold also upper part of bedrock. Nuggets valued at $\$ 2.75$ and $\$ 11.50$ reported.

p. 110 - Depth to bedrock 50-317 ft.

p. 112-113 -- Product1on, 1908, worth $\$ 12,000$. Gold worth

\$18.11 per oz.

Brooks, 1914 (B 592), p. 68 -- New discovery made, 1913.

Chapin, 1914 (B 592), p. 361 - Mining, 1913.

Smith, 1917 (BMB 142), p. 23 -- Mining (not extensive), 1915.

Smith, 1917 (BMB 153), p. 51 - Mining, 1916.

Sinth, 1930 (B 810), p. 25 - Mining, 1927. 
Soclal Security

Fa1rbanks district

MF $-410,10 \mathrm{c}, 6$
Gold

Falrbanks $(14.3,15.0)$

$64^{\circ} 51^{\prime} \mathrm{N}, 148^{\circ} 05^{\prime} \mathrm{W}$

Sumary: Gold 1n a lode prospect. No other data.

Chapman and Foster, 1969 (P 625-D), P. D19-- Gold in a lode prospect. No other data. 
(Spruce Cr.)

Bonnifleld district

MF-410, 10c. 38
Antimony, Gold, S1lver

Falrbanks (8.25, 1.55$)$

$64^{\circ} 05^{\prime} \mathrm{N}, 148^{\circ} 55^{\prime} \mathrm{W}$

Summary: Jamesonlte-bearlng velns contain $0.44 \mathrm{oz}$. gold and $5.4 \mathrm{oz}$. sllver per'ton. Gold-bearing quartz velns also present.

Joest1ng, 1943 (TDM 2), p. 14 -- Ant1mony-bearlng velns and gold-quartz velns near head of creek. Sample of antimony-bearing veln contalned arsenopyrite, scorodite, and Jamesonite. Assay indicated $0.44 \mathrm{oz}$. Alt and $5.4 \mathrm{oz}$. Ag per ton.

Berg and Cobb, 1967 (B 1246), p. 202-203 -- A few gold-baring lodes and small jamesontte-bearlag veins. 
Spruce Hen

Falrbanks dictrict

MF-410; 100. 29
Molybdeaum, Tungsten; Fluor1te

Falrbanks $(18.5,17.1)$

$64^{\circ} 57^{\prime} \mathrm{N}, 147^{\circ} 31^{\prime} \mathrm{W}$

Sumary: Schist with some Interbedded limestone and metamorphosed basic igneous roek. Lode is a skam deposit with scheelite. fluorite, garnet, and other typical contact-metamorphic minerals that replaced liwestone; about $3 \mathrm{ft}$. thlck. Lode $1 \mathrm{~s}$ cut by scheelite-bearing quartz veln. Scheelite in zones in blocks of altered Igneous rock (mainly hornblende) on dump. A Iftele molybdentte reported in ore. Workings consisted of $70-\mathrm{ft}$. Inclined shaft, plts, and trenches. No record of any production.

Mertie, 1918 (B 662), p. 422-423-- Along webcern perfphery of large body of porphyritic grantte. 5 lodes being prospected by trenches. One lode is 3-4 ft. wide, made up of schist and metamorphosed basic rock, and averages 1-2 percent scheelite; no gold. A siotlar lode $1 \mathrm{~s} 4 \mathrm{ft}$. wide, strikes $\mathrm{N} 33^{\circ} \mathrm{E}$, and dips $40^{\circ} \mathrm{NW}$.

Chapin, 1919 (B 692), p. 326-327 -- Sillcates have replaced limestone beds and are cut by quartz velas; both rich in scheelite; also a little molybdentte. Seams of gouge along both walle of lode, which strikes $\mathrm{N} 50^{\circ} \mathrm{E}$ and dips $45^{\circ} \mathrm{NW}$.

Mart1n, 1920 (B 712), p. 40 -- Some work done, 1918.

Sutth, 1942 (B 926 C), P. 196 -- Reference to B 692, p. 326-327.

Thome and others, 1948 (RI 4174), p. 24-25 - Quotation from B 662 .

Byers, 1957 (B 1024-I), P. I88-- Ground-water leaching of scheelite in weathered zone may have occurred.

p. 201-203 - - Staked by summer, 1916. Development work, 1916-18, consisted of 2 shafts (one to prospect for $801 d$ ) and mony pits and trenches. Inclined shaft reported to have been sunk $70 \mathrm{ft}$. on a $\mathrm{NW}$-dlpping ore body $3 \mathrm{ft}$. thick. Minerallzed zone trends $N 60^{\circ} \mathrm{E}$; appears to be more than one lode. In 1943 a plt and a trench exposed a badly weathered lode $3-3.2$ ft. wide. Small grains of scheelite are disgeminated through lode along with fluortte, gamet, and many ather typlcal contact-metamorphic winerals. Samples averaged $0.44 \%$ woj. Concentrations of scheelite in zones as much as $6 \mathrm{ln}$. wide in blocks of flne-gralned altered Igneous rock now mainly hornblende on an old dump.

Berg and Cobb, 1967 (B 1246), p. 220 -- On ridge between steele and Plrst Chance Creeks where the scheelite deposits are 1n tactice, slilcated limestone, granite and pegmat1t1c dikes, and small quartz veins in schlst.

Chapman and Foster, 1969 (P 625-D), P. Dl6 -- References to above reporto. Mulilgan, 1974 (IC 8626), P. 13 -- Data same as in P 625-D, P. DI6. 
Stay

Fatrbanks district $M F-410,10 c .19$
Antimony (?), Gold

Palrbanks (15.0, 15.2)

$64^{\circ} 51^{\prime} \mathrm{N}, 148^{\circ} 00^{\prime} \mathrm{W}$

Sumary: Quartz velns in schist near altered quartz porphyry; velos and schist wall rock minerallzed; quartz porphyry bas very 11ttle gold. Developed by several hundred feet of underground workings. Mlning oometime between 1910 and 1913 , in $1930-31,1933,1936$, and probably 1n some of the intervaning years; probably none since 1936. Total production not known; was about 700 cons that ylelded $\$ 16,000$ in gold for $1930-31$. May be some stibnite in ore. Includes references to Ltctle Eva.

Brooks, 1912 (B 520), p. 32-33 -- Little Eva clalm staked, 1910. About $180 \mathrm{ft}$. of underground workings; 12 -1nch veln found.

Smith, 1913 (B 525), p. 206-207 - Quartz veln trends $N 60^{\circ} \mathrm{W}$ and dips $68^{\circ}$ SW. Developed by shaft, tunnels, open cut. Eas1ly accessible ore stoped out; more mining would require pumping. [Occurrence not called by name.]

Smlth, 1913 (B 542), p. 192-193 -- Same as B 525.

H111, 1933 (B 849-B), p. 129-133 - Veln in L1ttle Eva workings 1s 6-18 10. wide, vertical, and strikes $\mathrm{N} 27^{\circ} \mathrm{W}$; offset to the left along several normal faults. Developed by adit $570 \mathrm{ft}$. long. Ore that panned an ounce or more per ton stoped out.above adit level; oeveral winzes. Elsewhere on property shafts 12 to $60 \mathrm{ft}$. deep developed slmilar velns; some of schlst wall rock also minerallzed. Bedrock at north end of property is altered quartz porphyry that does not carry much gold, even in quartz velnlets (strike $N 50^{\circ} \mathrm{W}$, dip $\left.50^{\circ} \mathrm{NE}\right)$. Total production in 1930-31 was about 700 tons of ore that yleIded about $\$ 16,000$ in gold when milled [no data on earller production]. Hill calculates about 1,350 tons of $\$ 15$ ore remalo in main vein at Little Bva workings.

Smtth, 1934 (B 864-A), p. 20 -- Some production reported, 1933.

Sm1th, 1938 (B 897-A), p. 22 -- Clatms leased; usual output not ma1ntalned; 1936.

Smtth, 1939 (B 910-A), p. 24 -- Part of Ready Bullion and Stay acquired by Bartholomae 01I Corp., 1937. Much activity, but no production.

Chapman and Foster, 1969 (P 625-D), P. D17 - Gold (has been mined) and atibnite (?) In quartz velns in schlst near a shatrered, Ironstalned, minerallzed quartz porphyry intrustve. 
(Stee1 (e) Cr., lode)

Fairbanka district
Gold

Fa1 rbanks $(18.85,17.0)$ $64^{\circ} 57^{\prime} \mathrm{N}, 147^{\circ} 27^{\prime} \mathrm{W}$

Summsry: Quartz veln with sparse gold. No data on tenor or record of type of probpecting.

Smlth, 1913 (B 525), p. 210 -- Prospecting; all ore In area sald to be low grade.

Smith, 1913 (B 542), P. 196 -- Same as B 525.

Chapman and Foster, 1969 (P 625-D), P. D16 -- Reference to B 525.

Mulligan, 1974 (IC 8626), P. 13 -- Quartz veln with sparse gold. 
(Steel Cr., placer)

Falrbanks district

\section{Gold}

Palrbanks (18.6,16.6)

$64^{\circ} 55^{\prime} \mathrm{N}, 147^{\circ} 30^{\prime} \mathrm{W}$

Sumary: Has been not particularly proflrable drift mining of deeply burled frozen gold placer.

Mulligan, 1974 (IC 8626), p. 14 - Deeply burled frozen gold placer. Drfft wining in early days reportedly not very profitable. Claims patented. 
Stepovich

Falrbanks district MF-410, Ioc. 32
Antimony, Beryll1um, Molybdenum, Tungsten

Falroanks $(19.6,17.6)$

$64^{\circ} 59^{\prime} \mathrm{N}, 147^{\circ} 22^{\prime} \mathrm{W}$

Summary: Crystalline limestone bed in schist that thlckened in crests and troughs largely replaced by calsilicate minerals, quartz, and scheelite; richest ore shoots at intersectlons of scheelite-bearing quattz pegtatites with I1mestone. Scheelite (not ore grade) in silicated schist. Other minerals in deposit include small amounts of pyrite, pyrchotite, molybdentte, and the berylifum mineral meliphanite. Lode offset by several steep faults. About 2,000 feet of underground workings. Total production, $1915-18$ and $1942-44$, was about 4,000 units of $\mathrm{WO}_{3}$. Includes references to: Alaoka Tungsten Mines, Johnson. Scheelite, and Tungsten if obviously to clatm of that name on this property.

Brooks, 1916 (B 642), p. 61-62 - In 1915 Johnson d1scovered a schee11te bearing lode in a crystalline limestone bed in schlat. Lode has been traced for $200 \mathrm{ft}$; a few Inches to $4 \mathrm{ft}$. wide. Opened by a 40-ft. 1ncline. Scheelite appears to be a primary mineral In a pegmatite.

Mert1e, 1918 (B 662), p. 419-421 - Scheel1te d1scovered In summer of 1915; minlng began in fall. Development, Aug. 1916, was 80-ft. Incline, 2 drifts. Bedrock largels crystalline limestone with some sllicated horlzons contalnting calclte, pyroxentte, hornblende, and quartz. Scheelite occurs disseminated in mineralized zones or as ore shoots in country rock. Scheelite In euhedral crystals and appears to be secondary [younger than?] to other rock minerals. Also a scheelite bearlng pegmatite. 210 tons of ore mined from Tungsten claim in 1915-16, conceotrated locally, and sold. 250 tons of unconcentrated ore from lnclined shaft on Scheelite clatm shipped, 1915-16.

Chap1n, 1919 (B 692), p. 325-326 - Priacipal lode 1s parallel to schistosity of country rock (strike $\mathrm{N} 70^{\circ} \mathrm{E}, 20^{\circ}-40^{\circ} \mathrm{W}$ ); veln 2-12 ft. thick. Inclined shaft $160 \mathrm{ft}$. deep; stopes and chambers. M11 installed in 1917; in September turned out 500 1bs. concentrate per day. No work on Scheel1te cla1m in 1917.

Mart1n, 1920 (B 712), P. 40 -- Some work done, 1918; ta1ling to be remilled.

Cappa, 1924 (B 755), P. 148 -- Summary of data 1n B 662, p. 419-421. H111, 1933 (B 849-B), P. 157 - Only tungsten property on which there was development work in 1931.

Joesting, 1943 (TDM 2), p. 22-23 - Considerable surface and underground (about $200 \mathrm{ft}$. of shaft and drifts) exploration, 1942early 1943. About 110 tons of ore whth estimated $4.5 \%$ wO mined; 63 tons sold. Ore $1 \mathrm{~s}$ scheelite $1 \mathrm{a}$ zone of silicated Ilmestone and calcareous schist. 
Stepov1ch -- Cont1nued

Bafo, 1946 (IC 7379), p. 68 -- Tungsten mined during World War I. Examined in 1943 by USBM. In 1944 shipped I7 tons of $64.27 \%$ concenrrates and 12 tons of $15.56 \%$ materlal.

Thorae and others, 1948 (RI 4174), P. 4 -- USBM, USGS, and Alaska Terrltorlal Dept. of Mines Investigations, 1942-43.

p. 6-12 -- Clatme are along Btrike of Cleary Hill ore zone. First work done in 1915. In 1916-17 two Inclined shafts (deeper 180 ft.). were sunk. Through 1918 production was 10 tons concentrate $\left(65 \% \mathrm{wO}_{3}\right)$ and 300 tons sorred ore $\left(8 \pi \mathrm{wO}_{3}\right)$. 1942-44 mining was from a new inclined shaft $150 \mathrm{ft}$. on alope and 2 levels. Production wes 60 tons of ore $\left(4.55 \% \mathrm{wO}_{3}\right)$ and 38.3 tons of concentrate (49.7\% wo W $_{3}$. Property 1813 claims. Country rock malniy schlot; small crystallide limestone bodles; pörphyritic granlte. Scheelite mineralizacion generally parallel to cleavage of schtst; some dissemlnated in parts of grante. Contact metamorphic deposics; irregular small lenses in thin (no more than $20 \mathrm{ft}$. thick) Iimestone bed in Birch Creek Schlst; some scheelice in quartz velas. Maximum diameter of any one lens 18 not much more than 50 ft.; average thlckness about a foot; $1.5 \%$ to $20 \%$ wo, Gangue minerals are quartz, calcite, pyroxene, hornblende, gainet, sphene, and apatice. Pyrite, pyrrhotite, and molybdendte present but very rare.

p. 13, 15-23 - Details of USBM project; description of upderground work1ngs $(1,262 \mathrm{ft}$. total); and data on beneficlation testo.

Byerg, 1957 (B 1024-I), P. 183 - Cleary HL11 Mines Co. from 1942 to

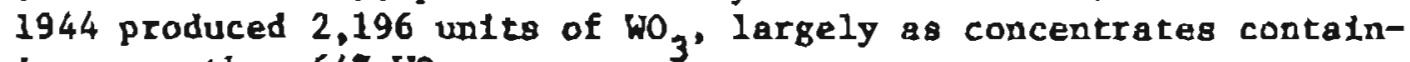
Ing more than $642 \mathrm{WO}_{3}$.

p. 188-198 - Since discovery in 1915 about 2,000 ft. of underground work has been done. During 1915-18 inclined shafts were driven down dip of 1ode. In 1931 a 170-ft. ad1t did not reach lode. In 1942-44 Cleary Hd1l Mines Co. sank 170-ft. Inclined shaft on lode with levels at $50 \mathrm{ft}$ and $150 \mathrm{ft}$. down Bhaft; ad1t Intersected drift on 150 Leval. World War I production was 10 tons concentrate (about $65 \mathrm{Z} \mathrm{WO}_{3}$ ) and 300 tons sorted ore (8\% $\mathrm{WO}_{3}$; only $2 \% \mathrm{WO}_{3}$ recoverable). Product1on $1942-44$ was about 98.4 tons of ore and concentrate that ylelded 2,196 unfts of $\mathrm{WO}_{3}$. Rocks that constitute lode are cryatalline 11megtone, granular scheelite ore (replacement of 21mertone), quartz pegmatite, and silicated mica schist (contains some scheplite, but not enough to be ore). Cryetalline Imestone is in discontinuous, Irregular bodies at same stratigraphic horizon in schlot; average thickness $2 \mathrm{ft}$; : way be $10 \mathrm{ft}$. In troughs and crests of folds; contains some gmall cavities. Granular scheolite ore locallzed at intersections of limestone and scheelite-bearing quartz pegmat1te; irregular lenses that replaced limestone. Typlcal contact-metamorphic minerals (including the beryllium mineral meliphanite) formed. Green amphibolite (metamorphosed 8111 or lava flow) form footwall of 


\section{Stepor1ch -- Conc1nued}

lode below 50 Level near shaft. Lode Benerally atrikes about N $70^{\circ} \mathrm{W}$, dips about $35^{\circ} \mathrm{NW}$; many variations because of dreg foldlng. Lode offset as much as several tens of feet along steep northward otr1king faults. Scheelite in upper part of lode in places aeem to.have been leached and redeposited. Welghted average tenor of 32 channel samplea $1 \mathrm{~B} 6.12 \mathrm{WO}_{3}$; tenor of mlned ore was oomewhat less than $5 \%$.

Bexg and Cobb, 1967 (B 2246), p. 220 - Total product1on, 1915-18 and 1942-44, was about 4,000 units of wo, L1mestone lenses largely replaced by, calcsilicate minerals, quartz, and scheelite. Richest ore shoots at intersections of limestone and pegmatite dikes.

Chapman and Foster, 1969 (P 625-D), P. D15 -- Reference to B 1024-I, p. $189-198$. 
Stepovich, M.

Fairbanks district
Gold (1)

Palrbanks (19.9, 17.55$)$

$64^{\circ} 59^{\prime} \mathrm{N}, 147^{\circ} 19^{\prime} \mathrm{W}$

Sumary: Quartz vein contalns bunches of arsenopyrite and a little pyrite; fractures cemented by scorodite. No data on possible gold content.

Smith, 1913 (B 525), p. 166 - Has been prospecting (1912).

Smlth, 1913 (B 542), p. 151 -- Same as B 525.

Chapin, 1914 (B 592), P. 330 -- 38-foot shaft sunk on quartz vein that strikes $\mathrm{N} 70^{\circ} \mathrm{E}$ and dips $70^{\circ} \mathrm{NW}$. Quartz on dump contains buitches of arsenopyrite and a little pyrite; fractuxes cemented by scorodite.

Chapman and Foster, 1969 (P 625-D), P. D15 -- References to B 525. B 592 . 
St1brite

Fafrbanke district

MF-410, loc. 14

\section{Antimony}

Eajtbanks $(14,85,15,551$

$64^{\circ} 52^{\circ} \mathrm{N}, 148^{\circ} 01^{\circ} \mathrm{W}$

Summary: Masslve stibnite lenses (largest was $100 \mathrm{ft}$. long, I ft. wide, $4 \mathrm{ft}$. thick) mixed with gchist in a shear zone that also contalos an 1ron-stalned quartz vein. 300 tons of ore mlned in 1915 and 1926. Deposit probably mined out.

Brookg, 1916 (B 642), p. 29 -- Productag mine, 1915.

Brooks, 1916 (B 649), p. 17 - Small-acale minlng, 1915.

p. $38-39$ - In shear zone in schiati strike about $N 30^{\circ} \mathrm{W}$, dip $70^{\circ}-90^{\circ} \mathrm{N}$. Iron-stalned quartz veln forms hanging wall of antimony lode. Shear zone 18 $1-2-1 / 2 \mathrm{ft}$. wide and has been traced for about $150 \mathrm{ft}$. Stibnite shoots are pods or lenses that pltch northward and 1n smaller kldneys of ettbnite, quartz, and fragments of achist. Stibntte 18 in granular aggregates with some columar masses; some has baen sheared. Gangue is vitreous quartz. ore shipped was hand broken and sorted from open cuts and plts.

Joesting, 1942 (TDM 1), P. 8 -- Reference to B 649.

Ebbley and Wright, 1948 (RI 4173), P. 38 - About 300 tons of ore produced from large stibnlte lenses.

K11leen and Mertle, 1951 (OF 42), P. I2 -- Or sample contalned 45.65\% $\mathrm{Sb}$.

p. 14-15 -- Significant quantities of stibnite have been mined. Shear zone treads $N 17^{\circ} \mathrm{W}, \mathrm{dips} 70^{\circ}-89^{\circ} \mathrm{S}$, and is 12-30 in. wide; contalns tron-stalned quaxtz veln and lenseg of stibntte mingled with schlst; lenses pitch to the north. One lens was $100 \mathrm{ft}$. $\times 7 \mathrm{ft}$. $\times 4 \mathrm{ft}$. Total production, 1n 1915 and 1926, was 300 tons of stibnite. Shipments in 1915 contalned $51.57 \mathrm{Sb}$. Deposit probably mined out.

Berg and Cobb, 1967 (B 1246), p. 219 -- Shear zone 12-30 1n. wide cuts achlst, contains lenses of stibntte and quartz. Total past production, 300 tons of ore.

Chapman and Foster, 1969 (P 625-D), P. D18 -- References to B 649, P. $38-39$, and of $42, p .15$. 
Tanana

Fairbanks distrdet

HF-410, 10C. 27
Gold. Tungoten

Falrbanks $(18.3,17.0)$

$64^{\circ} 57^{\prime} \mathrm{N}, 147^{\circ} 32^{\prime} \mathrm{W}$

Sumbary: Auriferous quartz-scheelite velnlets ere in stingers of decomposed quartzite schlot that also carries some ocheelite and gold. Gold-quartz vein cuts scheelite lode, which is 3 ft. thick. No production.

Mert1e, 1918 (B 662), p. 422-423 - Act1ve prospecting, 1916. S1x scheelite lodes discovered on 5 clalms. Bedrock 18 quartzlte sch1st (sch1stosity strikes $\mathrm{N} 30^{\circ} \mathrm{E}$, dips $35^{\circ} \mathrm{NW}$ ). Scheelite in otringers of decomposed schist that contaln quartz-scheelite velnlets that carry oome gold; Bchlst also carrles scheelite and gold; zone $3 \mathrm{ft}$. thick. Gold-quartz vein (atrike $N \mathrm{~B}^{\circ} \mathrm{W}, \mathrm{dip} 60^{\circ} \mathrm{E}$ ) cutg scheelite lode. Prospect 16 along western periphery of large porphyritic granite body.

Capps, 1924 (B 755), P. 148 -- Data glumarlzed from B 662, p. 422-423. Thorne and others, 1948 (RI 4174), P, 23-24 - Quotation from B 662. Byers, 1957 (B 1024-I), P. 201 -- Had been located by summer of 1916. p. 204-205 - Not much could be seen In 1942-43. Quotation from B 662 , p. 422 .

Berg and Cobb, 1967 (B 1246), p, 220 - On ridge between Steele and F1rat Chance Creeks where the scheelite deposits are in tact1te, ollicated 11mestone, grantte and pegmatitic dikes, and small quartz veins in schist.

Chapman and Footer, 1969 (P 625-D), P. DI6 -- Reference to B 1024-I, p. 204-205.

Mulligan, 1974 (IC 8626), P. 13 - Same as P 625-D, P. D16. 
Thomas \& Resi

Falrbanke distrfct
Gold (1)

Fairbanks $(15.0,15.4)$ approx. $64^{\circ} 52^{\prime}$ R. $147^{\circ} 59^{\prime}$ is appFor.

Summary: Prospecting only.

SmIth, 1923 (B 525), p. 209 -- Prospecting, but no minting, in St. Patrick Cr. basin. Shafts $100 \mathrm{ft}$. deep sald to have been gunk on some properties and promlsing velns discovered. Thomas \& Hess were among those prospecting. A location ( 7 ) to shown on $\mathrm{f1g} .20$, p. 204.

Smith, 1913 (B 542), P. 195 -- Same as B 525. 
(Totatlan1ka R.) (Gr.)

Bonnlfield district MF-410, Iocs. 69-71
Gold

Fa1 rbanke (11.1-11.2,0.55-2.4)

$64^{\circ} 02^{\prime}-64^{\circ} 07^{\prime} \mathrm{N}, 148^{\circ} 32^{\circ}-148^{\circ} 33^{\prime} \mathrm{W}$

Sumary: Bedrock mainly schist cut by diliceous dikes and quartz velng. Stream flows through a succession of broad basing and sarrow canyons. Gold 18 in atream gravels, on bedrock, and in cracks and crevices in top fow feet of bedrock; may have been derlued from quartz velas or reconcentrated from nowremoved Tertiary bigh gravels. Mining began in about 1905 and continued intermittently unt1l as recently as 1940. Production, 1905-16, probably worth about $\$ 15,000$; no more recent daca, but undoubtedly ar much or more.

Prindle, 1907 (B 314), P. 208 209 -- Bedrock ma1nly Bch1st and andesite. Gravels derived from this bedrock and from coal-bearing deposits. Mining on gravel bars and in stream bed during low water stages. Gold in gravel, on bedrock, and in bedrock crevices. Gold flat. Mintag, 1906.

Brooks, 1911 (P 70), p. 172 -- Same as B 314.

Cappo, 1911 (B 480), p. 221-223 -- Preldminary to B 501:

Capps, 1912 (B 501), p. 44-45 -- M1ning in 1910. Large stream that flows through a succession of narrow canyons and broad open areas. Gold in gravels, on bedrock, and in top foot of bedrock where broken and decnyed. Only one clatm being worked in 1910.

Maddren, 1918 (B 662), p. 388 - Colors can be found almost any place from Callforata Cr. upetream for $20 \mathrm{mt}$. [into Bealy quad.]. Most of mining in middle basin from $1 / 2 \mathrm{mt}$. above Homestake $\mathrm{Cr}$. downotream to Murphy Canyon [not locatod, but assumed to be fust below mouth of Eourth of July $\mathrm{Cr}$. . .

p. 391-394 - Gold diecovered, 1905, and mined intermittently to 1916; total production worth about $\$ 15,000$. Bedrock 18 sch1st, cut by siliceous dikes and meny quartz velns, which Maddren considers as the source of the placer gold. Tertiary cosl-bearing rocks and Nensasa Gravel have been eroded away. Gold in typlcal stream gravels 4-6 ft. deep and in cracks in top 2-3 ft. of schist bedrock. Gold below mouth of [Fourth of] July Cx. probably derived from that creek.

Brooks and Capps, 1924 (B 755), p. 40 -- Mining neer mouth of Iron Cr., 2922.

Capps, 1924 (B 755), p. 138-139 - M1n1ng, 1922.

Moffit, 1933 (B 836), p. 345 -- Hydraullc plant betag 1nstalled, 1930.

Solth, 1939 (B 917-A), p. 54 -- Mla1ag, 1938.

Smith, 1941 (B 926-A), p. 51 - M10108, 1939.

Smdth, 1942 (B 933-A), p. 48-49 -- Mining. 1940. 
(Trixay Cr.)

Bonnffield district
Gold

Fa1rbanks

SE $1 / 8$ quad. (?)

Summary: Placer gold mined, 1937. No other data glven. Creek may also be known by another name; may be in Healy quadrangle.

Sutth, 1939 (B 910-A), p. 55 -- Placer gold mined, 1937. 
Tugngten B111

Falrbanks district

MF-410, 10c. 27
Gold, Tungsten

Fal rbanks $(18.3,17.0)$

$64^{\circ} 57^{\prime} \mathrm{N}, 147^{\circ} 32^{\prime} \mathrm{W}$

Sumarg: Scheelite in 4 zones as much as $14 \mathrm{ft}$. wide of decayed gchist. Cut by aurdferoug quartz veln. Specimeng of scheelite-bearing material on dump contained as wuch as $8 \% \mathrm{WO}_{3}$.

Mert1e, 1918 (B 662), p. 422-424 -- OD westerm per1phery of large porphryt1c granite body. Four scheelite lodes discovered by Aug. 1916. Scheelite in zones (as much as $14 \mathrm{ft}$. wide) of decayed schlst. Quartz veln contalning a l1ttle gold cuts one lode. Chap1n, 1919 (B 692), p. 327 -- Reference to B 662:

Joesting, 1943 (TDM 2), p. 23 -- L1ttle work since 1918. Specimens of hygh-grade ore (as much as 82 wO $_{3}$ ) on dumps.

Thorne and others, 1948 (RI 4174), P. $24-26$-- Quotations from B 662. Byers, 1957 (B 1024-I), P. 201 -- Had been located by gummer of 1916. p. 205 - Work done in 1916 obliterated by 1942-43. Quotat1on from B 662, p. 424.

Berg and Cobb, 1967 (B 1246), P. 220 -- On ridge between Steele and First Chance Creeks where scheelice deposits are in tactite, Bll1cated limestone, granite and pegmatitic dikes, and small quartz veins in schist.

Chapman and Foster, 1969 (P 625-D), P. D16 -- Reference to B 1024-I, p. 205.

Mulligan, 1974 (IC 8626), p. 13 -- Same as P 625-D, P. D16. 
Tyndall \& Fino(Ready Bullion Cr* ) Gold

Fafrbanks district

MF-410, 10C. 11

Fatrbanks $(14.7,15.15)$

$64^{\circ} 51^{\prime} \mathrm{N}, 148^{\circ} 02^{\circ} \mathrm{W}$

Sumary: Aurdferous quartz veln exposed in adtt.

Smith, 1913 (B 525), p. 208 - Several lode claimo explored by many openlngs, lncluding adits $60 \mathrm{ft}$. and $50 \mathrm{ft}$. long. Smal1-welldeflned quartz veln exposed in one adit; all gold appeara to be In valn.

Sm1th, 1913 (B 542), P. 194 - Same as B 525.

Chapman and Foster, 1969 (P 625-D). P. D19 - Reference to B 525. 
v.S. Smelt1ng, Reflning Mining Co. Blamuth, Gold. IIn, Tungsten

Falrbanks digtrict . Falrbanks

IN $1 / 2$ NE $1 / 4$ quad.

Sumary: Major gold placer operator of distr1ct with extensive operations on Citpple, Ester, Goldstream, Pedro and other creeks. Began preparatory work in 1925; began dredging in 1928; st111 operating in 1956. Channel samples of dump of dredge concentrates contalned $0.1 \% \mathrm{WO}_{3}, 2.23 \% \mathrm{tIn}$, and $0.01 \%$ bismuth. Successor to Fafrbanks Exploration Co.; see also U.S. SteltIng, Refintag Mining, Co., Livengood quad.

Moff1t, 1927 (B 792), P. 14, 17 - Preparations for large-scale operat1ons, 1925.

Sm1th, 1929 (B 797), P. 19-20 -- Ditch bu1lding and other preparatory work, 1926.

Smlth, 1930 (B 810), p. 25 -- Preparatory work, 1927.

Smlth, 1930 (B 813), p. 28-29, 47 -- Lerge-scale operattons; dredge on Goldstream, 1928.

Smith, 1932 (B 824), p. 32-34, 52 - Dredging, 1929.

Smith, 1933 (B 836), p. 24, 32-33, 54 -- Dredging, 1930.

Sm1th, 1933 (B 844-A), p. 32-33, 54 - Dredg1ng, 1931.

Smith, 1934 (B 857-A), P. 30-31, 51,-- Dredg1n8, 1932.

Sm1th, 1934 (B 864-A), P. 34-36, 56 - Dredg1ng, 1933.

Sulth, 1936 (B 868-A), P. 35-37, 58 - Dredging, 1934.

Sm1th, 1937 (B 880-A), p. 39-40, 61-- Dredging, 1935.

Sint th, 1938 (B 897-A), P. 46-48, 71 -- Dredg1ng, 1936.

Smlth, 1939 (B 910-A), p. 46-48, 76 -- Dredg1ng, 1937.

Sulth, 1939 (B 917-A), p. 43-46, 74 -- Dredg1ng, 1938.

Smlth, 1941 (B 926-A), p. 40-42, 70 -- Dredg1ng, 1939.

Sm1th, 1942 (B 933-A), p. 38-40,67 - Dredging and hydraul1ck1ng, 1940.

Ba1n, 1946 (IC 7379), P. 26-28 - Data on thawing, strippiag, and vital. stat1st1cs of dredges.

Byerg, 1957 (B 1024-I), P. 211 - - Channel samples of dump of all of the company's dredge concentrates concalned $0.1 \% \mathrm{WO}_{3}, 2.23 \% \mathrm{Sn}$, and $0.01 \% \mathrm{BI}$.

Pewe, 1958 (GQ-110) -- Between 1928 and 1948 company mined more than $\$ 100,000,000$ worth of gold (at 1956 price) [more than $2,857,000$ fine oz,] from the Falrbanks area. In 19568 gold dredge日 were operated. 
$\operatorname{Vog}(h) t$

Falrbanks district

MPP-410, 10c. 33
Blsmuth, Gold, Tungsten

Fairbanks $(19.65,17.8)$

$65^{\circ} 00^{\prime} \mathrm{N}, 147^{\circ} 21^{\prime} \mathrm{W}$

Summary: Quartz velng cut blotite grantte; contain Bcheellte and (in other parts of velns) Intergrowa gold, blemuch, and bismuthintee. Tellurlum determined chemlcally. Includes references to: Granlte H111, Monte Crlato, and blomuth near MeIba and Monte Crlsto Creeks.

Chap1a, 1914 (B 592), p. 325 - Native bismuth and blomuthialte 1n rich gold-bearlag veln quartz. Preaence of tellurium detected chemically. [Described as on Melba Cr.]

p. 330-331 - B1smuth-bearing gold quartz vein about 5 in. thlck trends east, 18 nearly vertical, and cuts blotite granite. Vigible gold plentiful in intergrown bismuth and bismuthialte and in quartz. Tellurium present, but mineral in which it occurs was not determined.

Mert1e, 1918 (B 662), p. 412 -- Country rock 1s porphyrit1c biot1te granlte. Two quartz velns separated by $3 \mathrm{ft}$. of shattered grantte otrike $\mathrm{N} 5^{\circ} \mathrm{W}$, dip $80^{\circ} \mathrm{W}$. They contain gold, ocheellte, blomuthIntte, and (according to assay) bome tellurium minaral. Scheelite and gold-b1smuth minerals (latergrown) do not occur in the same parts of the velns. Also reference to B 592, p. 330-331.

Brooks, 1919 (B 666), p. 98 - B1smuth in gold prospect [noted as on Melba Cr.].

Brooks, 1921 (B 714), P. 41 -- Reference to B 592, P. 330-331.

H111, 1933 (B 849-B), P. 71 - B1smuth and bismuthinite in very rich gold-bearlag veln quartz on Melba $C_{r}$; tellur lum present, but mineral assoclation not determined.

Wedow, Rilleen, and others, 1954 (C 331), P. 7 -- Reference to B 592, p. $330-331$.

Wedow, White, and othera, 1954 (C 335), P. 1-2 - Reference to $\mathrm{B}$ 592, P. 330-331; when visited in July 1949 vorkings were completely caved. Al1 that remained was highly disintegrated rock on dump around an old filled shaft and in the ruins of a gmall mill lonly mention of shaft or mill in literature]. No blamuth-bearing material could be found.

Chapman and Foster, 1969 (P 625-D), P. Dl5 -- References to above reports. 


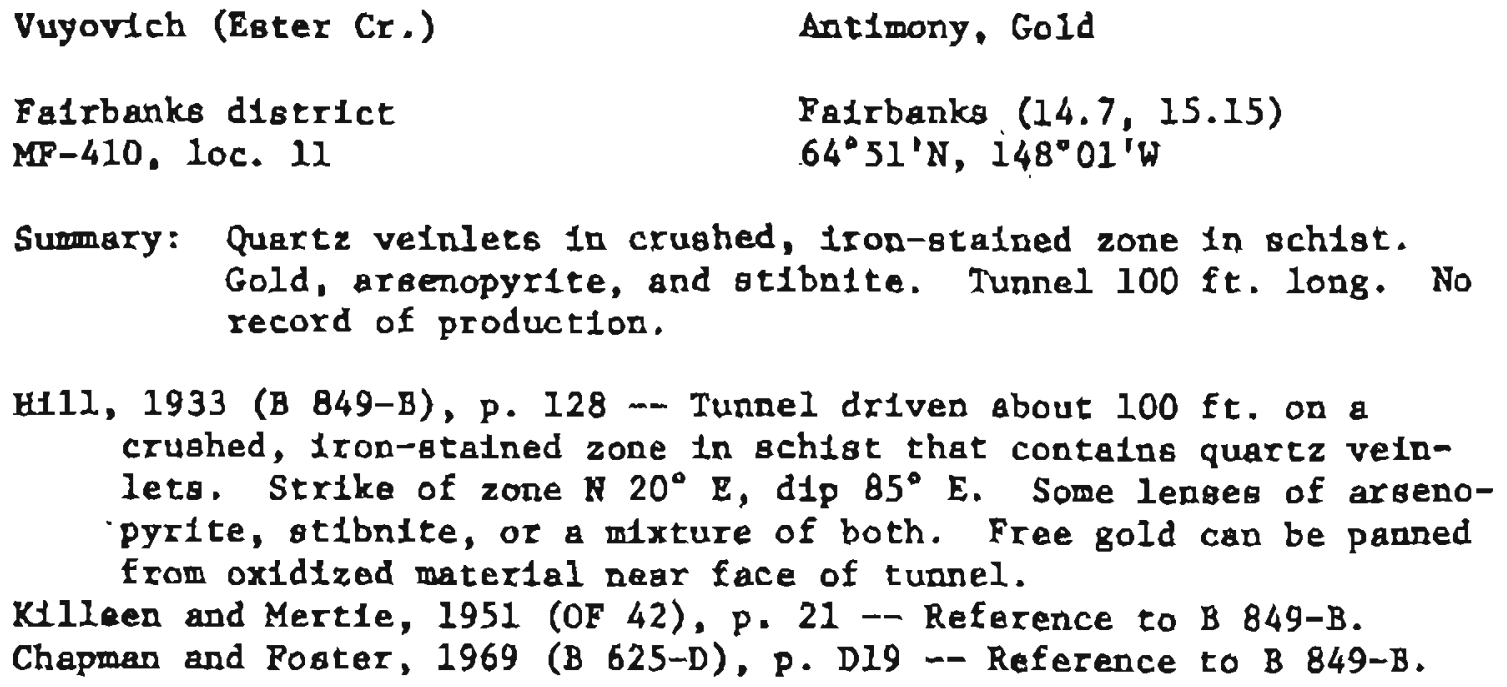

Vuyoulch (Ester Cr.)

Fairbanks district

MP -410, Hoc. 11

Antimony, Gold

Fairbanks (14.7, 15.15)

$64^{\circ} 51^{\prime} \mathrm{N}, 148^{\circ} 01^{\prime} \mathrm{W}$

Summary: Quartz veinlet in crushed, 1ron-stalned zone In schist. Gold, arsenopyrite, and otlbatte. Tunnel $100 \mathrm{ft}$. long. No record of production.

H111, 1933 (B 849-B), P. 128 - Tunnel driven bout $100 \mathrm{ft}$. on a crushed, 1ron-stalned zone in sch lot that contains quartz veinlets. Strike of zone $\mathbf{N} 20^{\circ} \mathrm{E}$, d $1 \mathrm{p} 85^{\circ} \mathrm{E}$. Some lenses of arsenopyrite, stibnite, or a mixture of both. Free gold can be panned From oxidized aerial near face of tunnel.

KIlleen and Bertie, 1951 (OF 42), p. 21 -- Reference to B 849-B.

Chapman and Poster, 1969 (B 625-D), P. D19 -- Reference to B 849-B.

165 
Vuyoulch (Ready Bullion Cr.) Gold

Falrbank diatrict Falrbanks $(14.55,15.55)$

MF-410, loc. $9 \quad 64^{\circ} 52^{\prime} \mathrm{N}, 148^{\circ} 03^{\prime} \mathrm{W}$

Summery: Rich ore sald to have been mined from a veln no more than 6 1n. thick In mica schist. Crushed, lron-stalned quartz on dump contalns free gold and arsenopyrite.

H111, 1933 (B 849-B), P. 128 - Vein, maximum width 6 in., otrikes about $N 50^{\circ} \mathrm{E}$; in mica schist. Tunael (caved in 1931) probably 50 to $60 \mathrm{ft}$. long. Some very rich ore sald to have been mined. Crushed, iron-stalned quartz on dump contalns free gold and arsenopyrite.

Chapman and Foster, 1969 (P 625-D), P. D19 -- Reference to B 849-B. 
Wander ing Jew

Fairbanks district

MP- $410,10 c .14$
Gold

Fairbanks $(14.85,15.55)$

$64^{\circ} 52^{\prime} \mathrm{N}, 148^{\circ} 00^{\prime} \mathrm{W}$

Summary: 120 tons of gold ore mined from white quartz vein 4 to 18

10. thick that io less crushed than most in the area. Shaft $50 \mathrm{ft}$. deep, $60 \mathrm{ft}$. of drifts, stope to the surface.

B111, ig33 (B 849-B), p. 147 - White quartz vein (some sulfides) 4-I8 In. wide strikes $N$ and dips $75^{\circ}-80^{\circ} \mathrm{E}$; not as badly crushed $a$ many In area; Iron and arsenic oxide stains; o ample assayed $\$ 25.35$ per ton. Developed by shaft $50 \mathrm{ft}$. deep, $60 \mathrm{ft}$. of drift, and a stope to the surface. On 30 -ft. level veld 18 cut off by a fault $25 \mathrm{ft}$. north of shaft. 75 tong of $\$ 21$ ore and 45 tons of $\$ 10$ ore mined, $1930-31$.

Chapman and Foster, 1969 (P 625-D), P. D18 -- Reference to B 849-B.

157 
White Association

Falrbanke district

MEF $-410,10 \mathrm{c} .36$

\section{Tungaten}

Palxbanks $(19.95,17.8)$ $64^{\circ} 59^{\prime} \mathrm{N}, 147^{\circ} 19^{\prime} \mathrm{W}$

Sumary: Ore shoot of scheel1te strikes $\mathrm{N} 75^{\circ} \mathrm{E}$, dips $75^{\circ} \mathrm{NW}$ along schlstosity of homblende and wica schists. Includes reference to Murphy clatm on Iellow Pup.

Mertle, 1918 (B 662), p. 421 -- Lode prospect1ng on placer cletms on Pearl Cx. One or more shafts encountered an ore shoot of scheellte in hornblende and mica schiets along schlotosity (otrlke $N 75^{\circ} \mathrm{E}$, dip $75^{\circ} \mathrm{N}$ ).

Chep1n, 1919 (B 692), p. 326 -- veln sald to be $4 \mathrm{ft}$. wide and to atrike $\mathrm{N} 75^{\circ} \mathrm{E}$.

Chapman and Foster, 1969 (P 625-D), P. D15 -- Reference to B 662, p. 421. 
Woodpecker

Palrbanks diatrict

MP-410, 10c. 30
Gold

Ealrbanke (18.6, 17.2) approx.

$64^{\circ} 58^{\prime} \mathrm{N}, 147^{\circ} 30^{\prime} \mathrm{H}$ epprox.

Sumary: Aurtferous weathered grante.

Chap1n, 1914 (B 592), P. 346 - Seame of quarte and quartz-feldspar rock in granite. Small quantitles of gold in weathered grante. Chapman and Foster, 1969 (P 625-D), P. D16 - Reference to B 592. MuIl1gan, 1974 (IC 8626), p. 13 -- "Aur1ferous weathered granite."

159 
Yellow Pup

Palrbanks district

MF-410, loc. 34
Tungsten

Fatrbanks $(19.8,17.6)$

$64^{\circ} 59^{\prime} \mathrm{N}, 147^{\circ} 20^{\prime} \mathrm{W}$

Summary: Quartz pegmat1te 1-2 ft. thick with acattered scheelite and apatite 18 between walls of garnet tact1te. Sample from 5ton ore pile contained $0.59 \% \mathrm{WO}_{3}$. Explored by $\mathrm{p} 1 \mathrm{ts}$ and a 12- $\mathrm{ft}$. tumnel; 35 tons of ore mined; mill test [amount of ore milled not stated] ylelded $225 \mathrm{1bs}$. of $70 \%$ wO 3 concentrate. Elsewhere on property (extension of Colbert lode) trenches exposed scheelite-bearlag garnet tactite and green silicate rock.

Ba1n, 1946 (IC 7379), p. 68 -- Examined by USBM in 1943.

Thorne and others, 1948 (RI 4174), P. 4 -- USBM estab11ahed cont1nulty between Yellow Pup and Colbert deposits.

p. 6 -- Clatme contiguous with those of Colbert property and adjoln south glde of Stepovich property.

p. 8-9 -- D1scovered, 1942. P1te and tuanel drtven $12 \mathrm{ft}$. on veln, which 18 cut of by a fault. 35 tons of ore from tunnel stockplled; mill test ylelded $225 \mathrm{Iba}$. of $70 \% \mathrm{WO}_{3}$ concentrate. USBM found faulted extension of vein. Property $1_{B} 6$ unpatented claims.

p. 14-16 -- USBM profect 3 short trenches; veln 1 continuous with Colbert mineralized zone. Tungsten mineralization forms a serfes of 1rregular lenses erraticaliy distributed horleontally and vertically; in places may comprise enough of replacement [of 1imestone] zone to constitute ore. Distance to underlying grante (on basis of magnetometer survey) Is probably 600-1,000 ft. USBM collected 6 samples from trenches.

Byers, 1957 (B 1024-I), p. 189 -- On apparent extension of Colbert lode to $\mathrm{NE}$.

p. 200-201 -- Scheellte-bearlag zone 1-2 ft. wide dlps steeply N. Footwall and hanging wall probably orlginally were garnet tactite. Ore is quartz pegmatite with acatered scheellte and apat1te. Exposed in open cut. Sample from 5-ton ore pile contalned $0.59 \% \mathrm{WO}_{3}$. Near west boundary of property pits and trenches exposed scheellke-bearlag garnet tactlte and green sllicate rock. Seem to be on extension of Colbert lade.

Berg and Cobb, 1967 (B 1246), p. 220 - About 1,000 ft. south of, para1le1 to, and simflar to Stepovich lode.

Chapman and Foster, 1969 (P 625-D), P. D15 -- Reference to B 1024-I, P. 200-201. 
Unoamed occurrence

Falrbanks district

$\mathrm{MF}-410,10 \mathrm{c} \cdot 4$
Ant1mony

Fatrbanke $(14.45,15.6)$

$64^{\circ} 53^{\prime} \mathrm{N}, 148^{\circ} 04^{\prime} \mathrm{W}$

Summary: Fragments of quartz-st1bnite veln make it appear that veln 18 2-3 ft." thick and strikes $N 60^{\circ} \mathrm{E}$. Country rock is schlst. No development of prospect (?).

Brooks, 1916 (B 649), p. 41 -- St1bnite-bear1ng ve1n. Cut about $75 \mathrm{ft.}$ long had caved when visited by Prindle in 1908. From fragments veln appears to be $2-3 \mathrm{ft}$. wide and to otrlke about $\mathrm{N} 60^{\circ} \mathrm{E}$. Country rock is mica-quartz schlot. Veln mater chlefly quartz and stibnite.

Chapman and Foster, 1969 (P 625-D), P. D19 - Reference to B 649. 
Synonyms, Claim Names, Operators, and Owners

Many mines, and prospects have undergone changes in both their own names and in the names of their operators and owmers. All names that appear in the cited refexences appear in this sumary either in the first section as occurrence names or in this as synonyms. Degcriptions of placer deposits ccmmonly give little information on the location of Individual mines or clains, so the names of all operators and owners of placer mines and claims are in this section with a notation to refer to the description of the stream that was mined or prospected. 
Adler - see Royal Flush

Aleska Metals Mining Co. -- oee Stepovich, Yellow Pup

Alabka Muneral \& Development Co. -- see Fyan

Alaska Tungsten Mines Co. -- see Stepovicb, White Assoclation

Aurore -- see Stepovich

Barlow \& Koska -- gee Rambler

Bartholomae 011 Corp. - see (Rex Cr.), Ready Bullion, Fyan, Soclal

Securlty, Stay

Beerpaw -- see Liberty Bell

Berry (\& Bamil Co.) -- see (Gold King Cr.)

Berton -- see (Cripple Cr.)

Bethys -- see Alexander \& Bethis

B1g Chief - see Colbert

Bigelow - see McDonald, Merian

( $81 \mathrm{~g}$ Moose Cr.) -- see (Moose C..)

B1Il Sunday Fraction -- see Billy Sunday

Black Bear - see Blossom

Black Diamond -- see Jennie $C$.

Blue Hira - - see Fair Chance, McDonald

Blue Bird Mining Co. -- see McDonald

Bonabolder -- see Mobawk

Borovich (\& Stevens) -- see Ready Bullion

Camp -- see Ready Bullion

Caucasian -- see steportch

Chippewan - see Stepovich

Christenson -- see Yellow Pup

Cleary H121 Mines Co. -- see Colbert, Stepovich

Columbia ning Co. -- see Columbia, Spruce Hen

Combination - - see McDonala

Comet - - see stay

Comstack - see Crown Point

Cosgrove \& Krutsct -- see Dorothy \& Dorlce

Curlew -- see Stay

Daly Bench - see (Eva Cr., Falrbanks a1st.)

Denzinger - see (Californta Cr., lode)

Diebold - see (Carlbou Cr., trib. California Cr.)

Edna - see Rran

(Eldorado Cr.) - see (BIg Eldorado Cr.)

(Esther Cr.) -- see (Ester Cr.)

Eva, Fairbanks alst. -- see Ryan

Eve Creek Mining Co., Bonnifield dist. - see Ltberty Bell 
Eva (Miniag Co.), Bonnifield dist. -- see Liberty Bell

Eva No. 2 - see Stay

Bve Quartz Minling Co., Bonnffield dist. -- bee Liberty Bell

Eva Quartz Minlng Co., Falrbanks alst. -- see Reedy Bujlion

Ewers -- see Stepovich;

Excelalor - - bee Ryan

Fa1rbenks Exploration Co. -- see U.S. Smelting, Refindas \& Mining Co.

(First Chance $\mathrm{Cr}$, , trib. FIsh $\mathrm{Cr}$. ) -- see (Iast Chance Cr.)

Frisco -r see Fadr Chance

Garnet -- see Yellow Pup

Gew - - see Fyan

General Joffre - - see Tungsten HIIl

Geneve -- see Ready Bullion

Golden Champion -- see (Cripple Cr.)

(Gold Hill) -- see (Crlpple Cr.), (Egter Cr.)

Gold Klag Fydreulic Miniag Co. -. see (Gold KIng Cr.)

Gold Lodes, Inc. -- see Ryan

(Gold Run (Cr.)) -- see (Gold KIng Cr.)

Goldotreas Mintag Co. - see (Goldstrean Cr.)

Grand Duke Níkoles -- see Tungsten Blil

Grante Eìll - see Vogt

Grant, neer Magget Cr. -- see Blue Bonanza

Grant \& H1rschberger -- see Tanana

Hanot Bros. - see (Pedro Cr.)

Hansen -- see (FHrst Chance Cr., trib. Goldstream Cr.)

Happy Creek - see Dorothy \& Dorice, Elmes

Happy Home -- see (Eva Cr, Fairbanks dist.)

Harrals -- see Mungsten H1ll

Hellerlch -- see Alexander \& Bethis

Henderson (\& McGIan) -- Bee Mohawk

Bess -- see Prometheus

Hightower - - see Mohawk

Horseshoe -- see Ready Bullion

Hosanna - see Fegay Ballion.

Fudson -- see Ready pullion

Fudson Bros. -- see Farmer

Ijim - - see Fran

Irene - see Liberty $\mathrm{Bell}$

Irlahman -- see Grant, near Happy Cr:

Ibagcson -- Bee Radge 
Jobnson -- see stepovich

Johnson, Norberg \& Erlckson -- aee Llberty Bell

Jolly Roger(s) — see Prometheus

(July Cr.) -- see (Fourth of July Cr.)

Kennecott Copper Corp. -- see Ryan

Keyв -- see (Moose Cr.)

Krutsich \& Cosgrove" -- see Dorathy \& Dorice

Leah -- see B1 1 y Sunday

Iean Fraction - - see B1Ily Sunday

Ltberty -- see Mobawk

Lttle Evs -- see Stay

Locle Fraction -- see Ready Bullion

Ione Tree -- bee Sanford

Lounsbury -- see Cllpper

Lucky -- see Steporich

Lundbled \& Anderson -- see Blossom

Makaich - - gee Silver Dollar

Marle -- see Yellow pup

Mary Stay - - see Ready Bullion.

M. B. Minlng Co. - see (Goldstream.Cr.)

McCann \& Olsea -- see Flower

McCann, Thomas, Mickley \& Hagel - see St. Paul

McDonala, Michley, Hess, Thomes McCann -. see clipper

McGlone - - see Fatr Chance

McGlone \& Sulth -- see Bllly sunday, Dorothy \& Dorlce, Fair Chance.

McLaughlin, Franklin \& Stay -- see Flrst Chance

Mcqueen - - see Jeanie $C$.

Meler (, Boffman \& Wallace) -- see Columbla

Melba -- see Yellow Pup

Mihalcik Bench - see (Ready Bull100 Cr.)

Midntight sun -- gee Blue Bonanza

Miller \& O'Connor - see Fatr Chance

Minfesota -- see (Eva Cr., Fairbanks dist.)

Monte - see Ryran

Monte Cristo - see Vogt

Montie -- see Rran

Murphy -- see (Foutth of July Cr.); Mother, Whtte Association

Murphy \& Perrault -- see Amerlcan, American Eagle

Murray \& Savage -- see Yellow Pup

NatIve Daughter -- see Ready Buzlion 


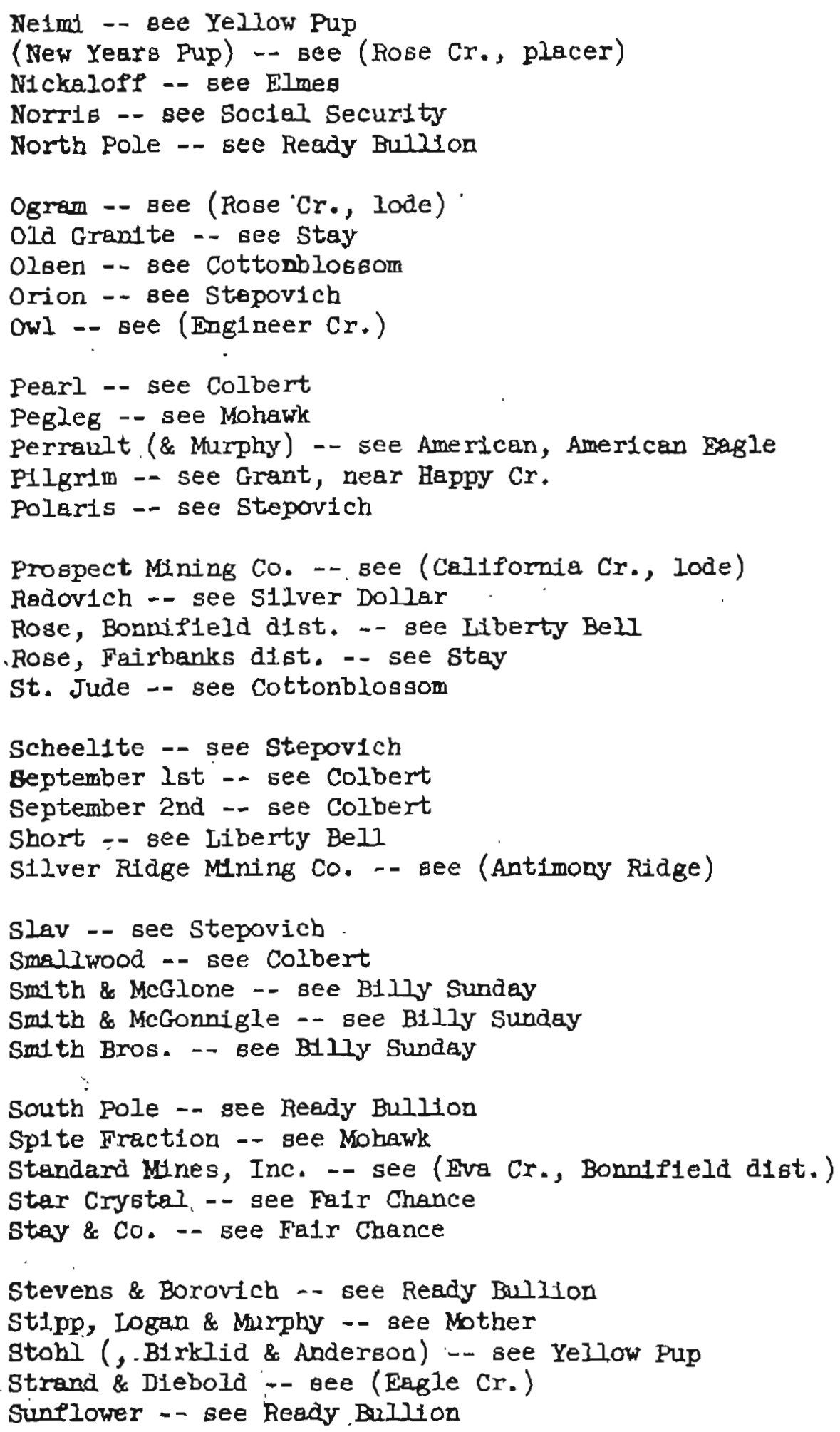


Sranson \& Mountalne -- see Iiberty Bell

Tytanic -- Bee Stepovich

Trlangle - - see Colbert

Triple X Placers - - see (Moose Cr.)

Tungsten -- see Stepov1ch, Tungsten H1.11

Turmbarge -- вee Lookout

Tyndell \& FInn, St. Patrick Cr. -- see Mohawk

Tyadais, Finn \& McGloughita -- see Mobewh

Tyndell, Finn \& McLaughlin - - see Mohawk

Tyndall \& Flynn -- see Mohetik

Tymdall, Henderson \& McLaughlin -- see Mohawk

Vemus -- see Stepovich

Verdin . see (Fox Cr.)

Wlld Goose, Bonnifleld dist. -- see Lfberty Bell

Wid Goose, Fairbanks dist. -- see (Engineer Cr.)

Yeljow Jacket -- see Mohawk

(Yellow pup Cr.) -- bee (Peerl Cr.)

Zimerman -- see Frankl1n, Ptarmbgan, Spruce then 


\section{Refarences Cited}

References are 118ted In atandard farmat alphabetically by author and, secondarily, chronologlcally if an author prepared more than one report or map. This section was prepared by stacking blbl1ography carde in a document protector and duplicating them on an office copying machine. This procedure makes fetyplag unnecessary, but has the disadvantages that the edges of cards reproduce as horfzontal Ines between entrles and that marglas and spacing are not constant. 
Ba10, H. F., 1946, Alaske's minerels as a basis for lndustry: U.S. Bur. Mi.res Ins. C1rc. $7379,89 \mathrm{p}$.

BerB, B. C., and Cobb, E. H., 2967, Metalliferous lode depostte of Aleske: U.S. Geol. Survey Bull. 2246,254 p.

Brooks, A. H., 1907, The mining 1ndustry 10 1906: U.S. Geol. Survey Buil. 314, p. 19-39.

Brooks, A. H., 1908, The mining Industry in 1907: U.S. Geol. Survey Buבz. 345, p. 30-53.

Brooks, A. B., 1910, The mining 1ndustry 1n 1909: U.S. Ceol. Survey Bul1. 442, p. $20-46$.

Brooks, A. H., 1911, The Mount Makinley region, Alaska, with descriptions of the igneous rocks and of the Bonnifiela end Kantishna districts, by L. M. Prindle: U.S. Geol. Survey prof. Peper 70, $234 \mathrm{p}$.

Brooks, A. H., 1911, Geologic features of Alaskan metalliferous lodes: v.S. Geol. Survey Bull. 480, p. 43-93.

Brooks, A. A., 1918, The mining 1ndustry in 1912: U.S. Geol. Survey Burl. 520, p. $17-44$.

Brooks, A. H., 2914, The Alaskan ming Industry in 1913: U.5. Geol. Survey Bulz. 592, p. 45-74.

Brooks, A. H., 1915, The leskan mining industry in 2914: U.S. Geol. Survey Bulz. 622, $\mathrm{p}$ 15-68.

Brooks, A. H., 1916, The Alaskan mining industry in 1915: U.S. Geol. Survey Burl. 642, p. 16-71.

Brooks, A. H., 1916, Antirony deposits of Alaska: U.S. Geo1. Survey Buill. $649,67 \mathrm{p}$.

Brooks, A. R., 1918, The Alaskan minling 1ndustry in 2916: U.S. Geol. Survey Bull. 662, p. 11-62.

Brooks, A. H., 1919, Alaska's mineral supplies: U.S. Geol. Survey Buzl. 666 , p. 89-102.

Brooks, A. H., 2921, The future of Alaske minting: U.S. Geol. Survey BuI1. 724, p. 5-57.

Brooks, A. H., 192e, The Alaskan mining 1ndustry in 2920: U.S. Geol. Survey Bull. 722 , p. T-67.

Brooks, A. H., 1923, The Alaskan mintug industry in 2921: U.S. Geol. Survey Bull. 739 , p. 1-44. 
Fairbanks quadrangle

Brooks, A. H., 1925, Alaska'B mineral resources and production, 1923: U.S. Geol. Survey Bull. 773 , p. 3-52.

Brooks, A. H., and.Capps, S. R., 1924, The Aloskan mining industry ir 2922: U.S. Geol- Survey Bul. $755, \mathrm{p} .3-49$.

Brooks, A. B., and Mart1B, G. C., 1921, The Alaskan mining 1ndustry 10 1919: U.S. Ceol. Survey Buil. 714, p. 59-95.

Burand, W. M., 1966, A geocbemical Investigation of the Nenana Highway area, central Alaska: Alaska Div. Mines and Minerals Geochem. Rept. $10,13 \mathrm{p}$.

Byers, F. M.; Jr., 1957, Mungsten deposits in the Fairbanks district, Alaska: U.S. Geol. Survey Bull. 1024-I, p. 179-216.

Capps, S. R., 1911, Mneral resources of the Bonnlfleld region: U.S. Geol. Survey Bu3l. 480, p. 218-235.

Capps, 5. R., 1912, The Bonnifield region, Alaska! U.S. Geol. Survey Bull. 501, $64 \mathrm{p}$.

Capps, 5. R., 1924, Geology and mineral resources of the reglon traversed by the Alaska Ratlroad: U.S. Geol. Survey Bull. 755, p. 73-250.

Chapin, Theodore, 1914, Lode mining near Falrbonks! U.S. Geol. Survey Bull. '592, p. $321-355$.

Chapin, Theodore, 1914, Placer mining in the Yukon-Tanana region: $4^{\circ} .5^{\circ}$ Geol. Survey Bull. 592, p. 357-362.

Chapin, Theodore, 1919, Mining in the Fairbanks distr1ct: U.S. Geol. Survey Bull. 692, p. 321-327

Chapmen, R. M., and Foster, R. L., 1969, Lode mines and prospects in the Falrbanks distrlct, Alaska: U.S. Geol. Survey Prof. Paper 625.-D, p. DI-D25.

cobb, E. H., 1972, Metelilc mineral resources map of the Fatrbarks quadrangle, Alaska! U.S. Geol. Survey Misc. Field Studies Map MF-410, 1 Bbeet, scale 1:250,000.

Cobb, E. H., 1973, Placer deposits of Alaske: U.S. Geol. Survey Bull. $1374,213 \mathrm{p}$.

Eakin, H. M., 1915, Mining in the Fairbanks district: U.s. Geol. Survey Buli. 622, p. 229-238.

Ebbley, Norman, Ir., and Wrigbt, W. S., 1948, Antimony deposits in Alaska: U.S. Aur. Mines Rept. Inv. 4273, 41 p. 
Falrbanks quadrangle

Eckhart, F. A., 1952, Clay, near Nerana: U.S. Geol. Survey open-file report $66,6 \mathrm{p}$.

Eliswortb, C. E., 2910, Pleccr mindne in the Yukon-Ienane reglon: U.S. Geol. Survey Bul1. 442, p. 230-245.

Ellwworth, C. E., 1912, Placer ming in the Fairbanks and Circle districts! U.S. Geol. Survey Bull. 520, p. 240-245.

Ellswortb, C. E., and Devenport, R. $\dot{H}^{\circ}$, 2913, Placer mining in the YukonTanan region: U.S. Geol. Survey Bull. 542, p. 203-222.

Elisworth, C. E., and Parker, G. I., 1911, Placer mining in the YukonTanana region: v.S. Geol. Survey Bull. 480, p. 153-172. ...

Hesler, J. W., Miller, M. H., and Chepmen, R. M., 1973, Bismuth, in Brobst, D. A., and Pratt, W. P., eds., United States rifinerel Tesources: U.S. Geol. Survey Prof. Paper 820, p. 95-98.

Hi11, J. M., 1933, Lode deposits of the Fairbanks district, Alaska: U.S. Geol. Survey Bull. 849-B, p. 19-163.

Joesting, H. R., 1942, strategic mineral occurrences in interior Alaska: Alaske Dept. Mines Pamph. 1, 46 p.

Joesting, B. R., 2943, Suppilement to Pamplęt No. 1 - Stratejgic mineral occurrences in laterlor Alaska: Alaska Dept. Mines. Pamph. 2, 28 p.

Killeen, P. L., and Mertie, J. B., Jr., 1951, Antimony ore in the Fatrbanks district, Alaske: U.S. Geol. Survey open-file report 42, $43^{\circ} \mathrm{p}$ :

Koschmany, A. H., and Bergendabl, M. B., 1968, Principel goldproducing district of the United States: U.S. Geol. Survey Prof. Paper 610, 283 p.

Meddren, A. G., 1918, Gold placers near the Nenana coel Fleld: U.S. Geol. Survey Bull. 662, p. 363-402.

Malone, Kevin, 1962, Mercury occurrenceis in Alaska: U.S. Bur. Mines Inf. Circ. $8131,57 \mathrm{p}$.

Malone, Kevin, 1965, Mercury in Alaska, in U. S. Bureau of Mines, Mercury potential of the United States: U.S. Bur. Mines Inf. c1rc. 8252 , p. 31-59.

Martin, G. C., 1919, The Alaskan minibe 1ndustry in 1917: U.S. Geol. Survey Burl. 69R, D. 11-42.

Martin, G. C., 1920, The Alaskan mining 1ndustry in 1918: U.S. Geol. Survey arl. T12, p. 11-52. 
Falntianks áuadrangle

Mert1e, J. B., Ir., 1918, Lode mining in the Falrbanks district: U.S. ceo1. Survey Bul1. 662, p. 403-424.

Moffit, F. H., 1927, Mineral 1ndustry of Alskka in 1925: U.S. Geof. Survey Bull. 792, P. I-39.

Maff1t, F. R., 1933, Mining developments in the Tatianike and Totatianike besinf: U.S. Geol. Survey BuII. 836, P. 339-345.

Mulilgan, J. J., 1974, Mineral resources of the trans-Alaska plpeilde corridor: U.S. Bur. Mines Inf. C1re. 8626, $24 \mathrm{p}$.

Overbeck, R. M., 1918, Lode deposits near the Nenene coll fieldi U.S. Geol. Survey Buil. 662, p. 351-362.

Fewé, T. I., 1958, Geology of the Fal rbanks (D-2) quadrangle, Alakka: U.S. Geol. Survey Geol. Quad. Map GQ-110, 1 sheet, scale 1:63,360.

Plukington, B. D., Forbes, R. B., Hawkins, D. B., Chapman, R. M., and swalnbank, R. C., 1969, Prellmiuary investigation of gold mineralization In the Pedro Dome-Cleary Sumit area, Falrbanks district, Alaska: U.S. Geol. Survey open-file report $383,47 \mathrm{P}$.

Prinale, I. M., 2905, The gold placers of the Fortymle, Btrch Creek, and Fajrbanks regions, Alagka: U.S. Geol. Survey Bull. 251, $89 \mathrm{p}$.

Prindle, L. M., 1906, Yukon plecer fields: U.S. Geol. Survey Bul.l. 284, p. 109-127.

Prindle, L. M., 1907, The Bonnifield and Kantishnt regions, Alaske: U.S. Geol. Survey Bull. 324, p. 205-226.

Prindle, L. M., 1908, The Fairbanks and Rampart quadrangles, YukonTapona region, Alaska,'with a section on the Rampart placers, by F. L. Hess, and a papes on; the water supply of the Falrbanks region, by C. C. Covert:"U.S. Geol. Survey Bull. 337, 102 p.

Prindle, L. M., and Katz, F. J., 1909, The Falrbanks gold-placer reglon: U.S. Geol. Survey Bull. 379, p. $181-200$.

Prindle, I. M., and Katz, F. J., 1913, Geolosy of the Fairbanks district, in Prindle, L. M.2 A geologic reconnaissance of the Fairbanks guadrangle, Aleska: U.S. Geol. Survey Bull. 525, D. 59-152.

Purington, C. H., 1905, Methods and costs of gravel and placer mining 1n Alaska: U.S. Geol. Survey Bul1. 263, 273 p.

Rutledge, F. A., Mome, R. L., Keras, W. H., and Muligar, J. J., 1953. Prellalnary report: Nonmetall1c deposits accessible to The Alaska Railroad as a.possible source of raw materlels for the construction industry: U.S. Bur. Mines Rept. Inv. 4932, $129 \mathrm{p}$. 
Fäirbanks quadrengle

Smitk, P. S., 1913, Lode mining near Falrbanks, in Prindie, L. M., h. geologic raconnalssance of the Fairbanks quadrangle, Alaska: U.S. Geol. Survey Bull. 525, p. $153-216$.

Smith, P. S., 1913; Lode mining near Falrbanks: U.S. Ceol. Survey Eull. 542, p. $137-20 \%$.

Solth, P. S., 2926, Mtneral industry of Alaske 1n 1924: U.S. Geol. Survey Bull. 783, p. 1-30.

South, P. S., 1929, Mineral industry of Aleske in 1926: U.S. ceol. Survey Bull. 797, p. 1-50.

Smith, P. S., 1930, Mineral Inalustry of Alacks 1n 1927: U.S. Geol. Survey Buli. 810, p. 1-64.

Smith, P. S., 1930, Mineral 1ndustry of Alaska in 1928: U.5. Geol. Survey Bull. 813, p. 1-72.

Smith, P. S., 1932, Mineral industry of Alakka in 2929: U.S. Geol. survey_Bull. 824, p. 1-81.

Sutth.F. S., 1933, Mineral industry of Alasks in 1930: U.S. Geol. Survey Bull. 836, p. 1-83.

salth, P. S., 1933, Mtneral industry of Alaske tî 1931: U.S. Geol. Survey Ball. 844-A, p. 1-82.

sintb, P. S., 1934, Mineral industry of Alaske in 1932: U.S. Geol. Survey Bull. 857-A, p. 1-91.

Solth, P. S., 1934, Mineral industry of Alaska in 1933: U.S. Ceo1. Survey Bu]1. 864-A, P. 1-94.

Solth, P. S., 1936, Mineral industry of Alaske tr 1934: U.S. Geol. survey Euli. 868-A, p. 1-91.

Smith, P. S., 1937, Mineral industry of Alaska tu 1935: U.S. Geol. survey Bull. 880-A, p. 1-95.

Smith, P. S., 1938, Mineral indugtry of Alaska 1n 1936! U.S. Ceol. Survey Bu]l. $897-A$, p. 1-107.

Sinth, P. S., 1939, Mueral industry of Aleske in 1937: U.S. Geol. Survey Bul1. 910-A, p. 1-113.

Sultb, P. S., 2939, Mineral 1ndustry of Alsske In 1938: U.S. Geol' Survey Bul1. 917-A, p. 1-113.

Snltb, P: S., 1941, Minerel Industry of Alaska in 1939: U.S. Geol. Survey Buli. 926-A, p. 1-106.

173 
Smith, P. S., 1942, Occurrences of molyodenum minerals in Alaska: U.S. Seol. Survey Buld. 926-C, p. 161-210.

Sidth, P. S., 1942, Mineral 1 ndịutry of Alaske in 1940: U.S. Geol. Survey Buzl. 933-A, p. 1-102.

Sulth, S. S., 1917, The mintng industry in the Territory of Alaske during the calendar year 1915: U.S. Bur. Mines Bu31. 142, 66 p.

Smltb, S. S., 1917, The mining 1ndustry in the Territory of Alaska durlng the calendar year 1916: U.S. Bur. Manes Bul. 153, 89 p.

Thorne, R. I., MulY, N. M., Erlekson, A. W., Thomas, B. I., Helde, H. E., and Wright, W. S., 1948, Tungsten deposits in Alaske: U.S. Bur. Mines Rept. Inv. 4174, 22 p.

Warfield, R. S., and Thomes, B. I., 1972, Rotary drilling exploration of the Fyen lode properties, Fairbanks mining district, Alakka: U.S. Bur. Mines open-file rept. 23-72, 21 p.

Waring, G. A., 1947, Nonmetalliferous deposits in the Alaske Rellroad belt! U.S. Geol. Survey C1re. 18, $10 \mathrm{p}$.

Wedow, Helmuth, Jr., Killeen, P. L., and others, 1954, Reconnaissence for radiosctive deposits in enstern 1nterior Alaske, 1946: U.S. Geol. Survey Circ. 331, $36 \%$.

Wedow, Beimuth, Jr., White, M. G., and Moxiem, R. M., 1952, Interim report on an appralsal of the uranium possibilities of Alaska: U.S. Geol. Survey open-file report 51, $123 \mathrm{p}$.

Wedow, Hejmuth, Ir., White, M. G., and others, 1954, Reconneissance for radioactive deposits in east-central Alaska, 1949: U.S. Geol. Survey C1rc. 335, $22 \mathrm{p}$.

Whdte, M. G., West, W. S., Tolbert, G. E., Nelson, A. E.:; and Houston, J. R., 1952, Preliminary surmary of reconnal ssance for urantum in Alasta, 1951: U.S. Geol. Survey C1rc. 196, 17 p. 